University of Louisville

ThinkIR: The University of Louisville's Institutional Repository

Electronic Theses and Dissertations

$12-2012$

\title{
The Ilkhanid Mongols, the Christian Armenians, and the Islamic \\ Mamluks : a study of their relations, 1220-1335.
}

Lauren Prezbindowski

University of Louisville

Follow this and additional works at: https://ir.library.louisville.edu/etd

\section{Recommended Citation}

Prezbindowski, Lauren, "The Ilkhanid Mongols, the Christian Armenians, and the Islamic Mamluks : a study of their relations, 1220-1335." (2012). Electronic Theses and Dissertations. Paper 1152.

https://doi.org/10.18297/etd/1152

This Master's Thesis is brought to you for free and open access by ThinkIR: The University of Louisville's Institutional Repository. It has been accepted for inclusion in Electronic Theses and Dissertations by an authorized administrator of ThinkIR: The University of Louisville's Institutional Repository. This title appears here courtesy of the author, who has retained all other copyrights. For more information, please contact thinkir@louisville.edu. 


\title{
THE ILKHANID MONGOLS, THE CHRISTIAN ARMENIANS, AND THE ISLAMIC MAMLUKS: A STUDY OF THEIR RELATIONS, 1220-1335
}

\author{
By \\ Lauren Prezbindowski \\ B.A., Hanover College, 2008 \\ A Thesis \\ Submitted to the Faculty of the \\ College of Arts and Sciences of the University of Louisville \\ in Partial Fulfillment of the Requirements \\ for the Degree of \\ Master of Arts \\ Department of History \\ University of Louisville
}

December 2012 


\title{
THE ILKHANID MONGOLS, THE CHRISTIAN ARMENIANS, AND THE ISLAMIC MAMLUKS: A STUDY OF THEIR RELATIONS, 1220-1335
}

\author{
By \\ Lauren Prezbindowski \\ B.A., Hanover College, 2008
}

A Thesis Approved on

November 15, 2012

By the following Thesis Committee:

Dr. John McLeod, Thesis Director

Dr. Blake Beattie

Dr. Charles Ziegler 


\section{ABSTRACT \\ THE ILKHANID MONGOLS, THE CHRISTIAN ARMENIANS, AND THE ISLAMIC \\ MAMLUKS: A STUDY OF THEIR RELATIONS, 1220-1335 \\ Lauren Prezbindowski}

November 15, 2012

This work seeks to fill a gap in the academic literature concerning the study of the Ilkhanid Mongols of the Middle East during the thirteenth and fourteenth centuries CE using Armenian, Persian, Arabic, and Syriac primary sources in English translation. This study will analyze the triangular relationship among the Ilkhanid Mongols, the Kingdom of Cilician Armenia and Greater Armenia, and the Egyptian Mamluks to discern the Ilkhanate's impact in the Middle East. Although the Armenians became subjects of the Mongols, they did not gain many benefits from this partnership. In fact, their relationship proved to be overwhelmingly negative. Although the Mamluks were adversaries of the Mongols, they ultimately benefited greatly from their adversarial stance by establishing and legitimizing the rule of the martial mamluk caste. This thesis seeks to show the importance of studying this triangular relationship and its impact on the medieval Middle East. 


\section{TABLE OF CONTENTS}

SECTION

PAGE

ABSTRACT.

iii

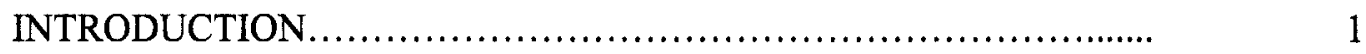

HISTORIOGRAPHY ................................................ 4

PRIMARY SOURCES............................................... 10

Armenian Sources................................................ 10

Persian Sources...................................................... 12

Arabic Sources..................................................... 14

Other Language Sources........................................ 15

THE PRELIMINARY HISTORICAL NARRATIVE................... 17

THE SECOND MONGOL INVASION OF PERSIA........................ 23

TERMS OF SUBMISSION TO THE MONGOLS....................... 29

THE DIVINE MANDATE AND ITS IMPACT ON RELATIONS........ 32

THE MONGOLS AND ARMENIANS................................ 40

Benefits of Mongol Allegiance................................. 45

Harmful Effects of Mongol Allegiance................................... 56

THE MONGOLS AND THE EGYPTIAN MAMLUKS.................. 74

Benefits of an Anti-Mongol Stance............................... 78

Negative Effects of an Anti-Mongol Stance....................... 89

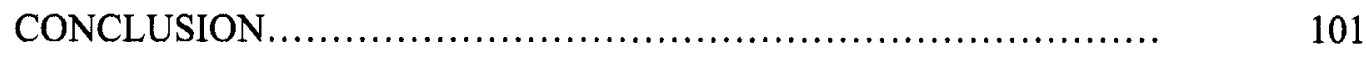

REFERENCES........................................................ 105

Primary Sources............................................ 105

Secondary Sources.............................................. 106

APPENDIX .............................................................. 110

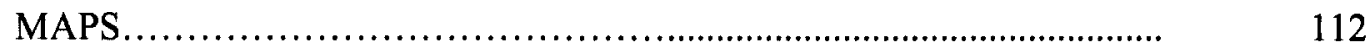

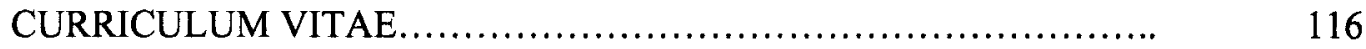




\section{INTRODUCTION}

In many ways, the thirteenth century CE can be characterized as 'the Mongol century.' By the middle of the century, most of Asia and large parts of Europe were under Mongol control, ruled by the four main branches of Chinggis Khan's family (the

Chinggisids). Chinggis' four sons by his first wife, Borte, formed the four Chingissid houses. After Chinggis's death, the sons fought over who would control the empire, even though Chinggis had designated his third son, Ogedei, as his successor. The eldest son, Jochi, led the Jochids and his successor Batu formed the Golden Horde, which controlled Russia and the northern Caucasus. Chinggis's second son, Chagatai, founded the Chagatids and ruled the lands in Central Asia nestled between China and Persia. The third son, Ogedei, assumed the mantle of Great Khan, a position which ruled over all the other khans, and ruled from the Mongol capital in Karakorum [Qaraqorum]. He also controlled the lands in China. The fourth and youngest son, Tolui, ruled the lands to the west, which included Persia and the southern Caucasus.

Inter-familial war remained a constant feature of the Mongol Empire and it was not until the mid 1200 s that the Great Khan was able to order the consolidation, and in some cases reconquest, of Mongol-controlled lands. The Great Khan Möngke of the Toluids set his two brothers, Kublai and Hülegü, to this task. Kublai would rule in the East (China) and Hülegü would rule in the West (Persia). 
This thesis focuses on Hülegü and his founding of the Ilkhanate. On his march west, the Mongol prince came into contact with numerous peoples and these relationships greatly defined how he would rule his new kingdom and how the Ilkhanate would exist in this political landscape. Mongol rule in Persia cannot be studied in a vacuum; scholars must understand the types of relationships the Ilkhans were involved in, what choices were available to them, and ultimately what defined their relationships with each of the region's peoples.

The arrival of a strong, permanent Mongol presence in Persia and the Caucasus greatly affected the politics of the area and brought a new political and military force into the mix. Some peoples, like the Armenians, saw the Mongols as a possible ally, whereas others, mainly the Egyptian Mamluks, saw the Mongols as a threat. Clearly, the Armenians and the Mamluks thought very differently about this new Mongol kingdom, and yet, they both had to address how they would interact with the Ilkhanid Mongols. The Armenians became the staunchest allies of the Mongols in the Middle East, while the Mamluks became the greatest threat to Mongol rule in the Middle East.

Despite their opposing stances, the Armenians and Mamluks both sought to take advantage of the new Ilkhanid presence. In fact, the Armenians and Mamluks came into direct contact with one another for the first time through their relations with the Mongols. A triangular relationship quickly developed among the Ilkhanid Mongols, the Armenians, and Mamluks, in which the decision-making or actions of one power greatly affected the other two. This thesis seeks to present and study this triangular relationship in detail and posits that in order to understand the thirteenth century history of any one of these kingdoms, the triangular Mongol-Armenian-Mamluk relationship ought to be studied. 
This thesis ultimately seeks to show that the Mamluks, as enemies of the Mongols, benefited more from their relationship with the Mongols than the Armenians, who were allies of the Mongols. This will be shown through a calculation of advantages and disadvantages for both the Armenians and Mamluks in regards to their relationships with the Ilkhanid Mongols. 


\section{HISTORIOGRAPHY}

\section{George Lane's work, Early Mongol Rule in Thirteenth-Century Iran: A Persian}

Renaissance, sought to show a more complex picture of the Mongol presence in Persia by showing distinctions between the first and second Mongol invasions of the area. Lane's work focused on the rule of the first Ilkhan Hülegü by showing complexities not addressed by many other secondary sources, giving equal consideration to both the positives and negatives of the Mongol presence in Iran. However, Lane's text did not take into account the transfer of the Caliphate from Baghdad to Cairo, nor did he completely flesh out the lasting impact of expelling the Caliphate from Baghdad. Lane's work also seemed to focus on internal matters in the Ilkhanate, while bypassing the importance of foreign relations, specifically the Ilkhanate's relations with the Egyptian Mamluks and Armenians. The Mongols and Mamluks contended for power in many different arenas, military, political, economic, and this would have impacted the Ilkhanate as a whole. This thesis will seek to incorporate more fully the impact of relations among the Mongols, Mamluks, and Armenians, especially in regards to early Mongol rule in Iran.

Reuven Amitai-Preiss's work, Mongols and Mamluks: The Mamluk-Ilkhanid War, 1260-81, wished to show the Mongol justifications for continued war against the Mamluks in Syria, as well as reasoning for Mamluk victory and Mongol defeat in Syria. Although the chief subject of this work was the Mamluk-Ilkhanid War, the study of this war is impossible without focusing on the role the Armenians had to play. Amitai-Preiss did not attribute much importance to the Mamluk drive to exact vengeance against the 
Armenians, nor did he much address the obligations of the Mongols to act as protectors of the Armenians. This thesis will seek to address both of these major concerns and show how such obligations and campaigns impacted the overall Mamluk-Ilkhanid War. This thesis will also take into account the complexities of the conflict, showing how the Mamluks, Mongols, and Armenians not only warred on the battlefield, but also in the throne rooms, mosques, pilgrimage routes, and trade caravans. Although Amitai-Preiss touches on a possible conclusion to the conflict, this thesis will clearly state and show how the Mamluks emerged victorious in the Mamluk-Ilkhanid War, by transforming the fierce Mongol enemy into a mighty political weapon.

Another work on the study of Mamluk-Mongol relations is Anne Broadbridge's work, Kingship and Ideology in the Islamic and Mongol Worlds. This work sought to study relations between the Ilkhanid and Jochid Mongols and the Mamluks through the specific lens of ideology and the motivations created by ideology. Broadbridge sought to compare and link the Mongol and Mamluk ideologies and the venues through which they communicated with one another. She especially focuses on the Mongol concept of the Divine Mandate, although she does not fully address its impact on relations. This thesis will not only show where and when the Divine Mandate was utilized, it will also show how the Mandate could be twisted against the interests of the Mongols, how it shaped the concepts and terms of submission the Mongols offered their enemies, and how ultimately the Divine Mandate did not work to the benefit of the Mongols' allies, mainly the Armenians. Still further, the thesis will show how the Mongols' pursuit of the Divine Mandate worked to the benefit of the Egyptian Mamluks. 
Although Broadbridge's analysis presented an extremely helpful understanding of the ideologies and kingship models of the Mongols and Mamluks, it did not address the Armenians or their ideology. At first glance this may seem appropriate given her study's focus, but this thesis will counter that even when studying Mamluk and Mongol relations as shaped by their ideologies, the impact of the Armenians is present. As much as the Muslim/heathen dichotomy was used between the Mamluks and Mongols, the Muslim/Christian dichotomy was also used. The Ilkhanid Mongols were continually attacked for the supposed favoritism they showed Christians, including the Armenians. When Arabic authors recounted the horrors of the Mongol attacks they explicitly speak about the atrocities committed by Christian (Armenian) warriors against the Muslims. Therefore, Broadbridge's work is missing some of the complexities present in MongolMamluk relations as a result of excluding the study of the Armenians.

Shifting now to Mongol-Armenian relations, Robert Bedrosian's work, The Turco-Mongol Invasions and the Lords of Armenia in the $13-14^{\text {th }}$ centuries, examined the impact of the Mongol invasions on the Armenian lordly rulers (naxarar). Bedrosian's work also sought to utilize and validate primary sources from Armenian authors as there has been much dispute over the impartiality of these authors. Bedrosian's work focused on the political and domestic demands made by the Mongols and the impacts of the Mongol conflict in Greater Armenia. But Bedrosian gave little attention to the terms of submission the Armenian princes had to accept from the Mongols. The Mongols instituted heavy taxes in some regions, while demanding a vast quantity of supplies and support for its armies. The cost of reconstruction and recovery after the Mongol invasion is also not discussed, nor is the cost of lives considered. This thesis will seek to address 
all of these issues and show how these demands negatively impacted the Armenians, both in the short and long term. Bedrosian also gave little attention to the impact of other external threats. These external threats, mainly the Mamluks, created the circumstances in which the Mongols placed their demands on the Armenian princes. As such, these external threats need to be factored into the study of Mongol-Armenian relations. An analysis of the Mamluk threat to the Armenians will also present an opportunity to analyze how the Mongol-Armenian alliance operated and what benefits it may have conferred on the Armenians. This thesis will present such an analysis and present the overall conclusion that the benefits the Armenians earned from their Mongol alliance did not outweigh its negative effects.

Bayarsaikhan Dashdondog's work, The Mongols and the Armenians (1220-1335), argued that the vast Mongol Empire would have been impossible to run without establishing and maintaining local political ties in its conquered lands. This work also sought to show how both parties, the Mongol commanders (later Ilkhans) and the Greater Armenian princes, benefited from their relationship. The study relied strongly on the works of contemporary Armenian authors. Chiefly among them were: Kirakos of Ganjak, Vardan Arewelci, Grigor of Akner, Stepannos Orbelian, and Stepannos Episkopos. Although Dashdondog's work utilized some Persian sources, it mainly utilized Armenian and Georgian sources, which limited its scope. This work talked about some of the connections between the Armenians and Mongols with the Mamluks, but the lack of Arabic sources limited the depth of the information provided. This thesis will take a more inclusive approach by utilizing Armenian, Arabic, Persian, and Syriac sources in 
translation and will analyze both the benefits and drawbacks of the Mongol-Armenian relationship.

For research on Armenian-Mamluk relations, Angus Donal Stewart's work, Armenian Kingdom and the Mamluks: War and Diplomacy during the Reigns of Hetum II (1289-1307), was consulted. Stewart's first argument was that no work has attempted to put the history of the Kingdom of Cilician Armenia into the wider context of the political climate of the Near and Middle East. Secondly, he stated that previous scholarship relied heavily on Crusader and Armenian primary sources, which usually left out the wealth of information Arabic sources have to offer. Stewart showed that one can clearly trace the Armenians' increasingly subservient status with respect to the Mamluk Sultanate chiefly through Arabic sources. He also analyzed the Cilicia Armenian-llkhanid Mongol relationship and succinctly showed the benefits the Armenians experienced from this partnership, but Stewart left some questions unanswered. Was the alliance with the Mongols beneficial in the long term for the Armenians? Would the Armenians and Mamluks have fought against one another without the Mongols? Such questions were left open to interpretation; this thesis will seek to answer these questions.

Finally, Robert Irwin's work, The Middle East in the Middle Ages: The Early Mamluk Sultanate 1250-1382, proved to be the best secondary source on showcasing the linkages among the Mongols, Armenians, and Mamluks. Irwin's work offered valuable insight into the mixing of Mongol and Mamluk cultures and peoples and how this mixing colored relations between the two. As with Stewart's work, Irwin left similar questions unanswered and did not provide a cost-benefit analysis of these relationships. This thesis 
will present such an analysis and present the conclusion that the Mamluks benefited the most from their interactions with the Mongols and Armenians.

Some of the sources mentioned above provided short-term analyses of certain benefits or aspects of a relationship, but no source ventured a longer-term analysis. A long-term analysis of these relationships and an analysis of advantages and disadvantages for all three powers are needed. This idea of advantages and disadvantages is particularly interesting and pertinent to studying the Mongol-Armenian-Mamluk relationship because the Mongols, especially the Ilkhanid Mongols, were new players to the region. Both the Armenians and the Mamluks consciously decided what type of relationship each would have with the Ilkhanid Mongols. Therefore, it is especially important to understand what choices were before them and how they went about making these decisions. Many such decisions are motivated by what is beneficial to the kingdom or its ruler, so a cost-benefit style analysis is useful in this thesis. This thesis will study what benefits each party sought to gain and then what the actual outcomes were and how these outcomes impacted those involved. This thesis will take a more holistic perspective by studying the triangular relationship among the Mongols, Armenians, and Mamluks. This thesis seeks to show that the Mamluks, as enemies of the Mongols, benefited more from their relationship with the Mongols than the Armenians, who were allies of the Mongols. This thesis seeks to address two gaps in present scholarship: the lack of a comprehensive analysis of Mongol-Armenian-Mamluk relations and the presentation of a definitive stance on who ultimately emerged victorious in the Mongol/Armenian-Mamluk rivalry. 


\section{PRIMARY SOURCES}

This study utilized a wide variety of primary sources, all found in English translation. The majority of primary sources were written during the time period discussed, the mid thirteenth century through the mid fourteenth century CE. Several other sources written in the fifteenth and sixteenth centurires were consulted. The contemporary sources utilized were written in medieval Arabic, Armenian, Persian, French, Latin, and Syriac.

\section{Armenian Sources}

The most helpful Armenian source was the Tatarats Patmutiwn, more commonly known as 'the History of the Nation of Archers,' written by Grigor of Akner (12501335). ${ }^{1}$ It described events relating to the Armenians from the time of Chinggis Khan to $1273 .^{2}$ Another important source from the period was the Patmutiwn Hayots (History of the Armenians) written by Kirakos of Ganjak (1200-1271). ${ }^{3}$ This work contained the political history of Armenia from its Christianisation (c. $301 \mathrm{CE}$ ) to $1266 / 67$. The source was most important because it included the first and second Mongol invasions of Armenia and gave the most detailed account of the Mongols from the Armenian

\footnotetext{
${ }^{1}$ Grigor of Akner, History of the Nation of Archers (the Mongols), trans. Robert P. Blake, Richard N. Frye, "Grigor of Akner's History of the Nation of Archers (the Mongols)," HJAS 12:3/4 (December, 1949): 269399.

2 Bayarsaikhan Dashdondog, The Mongols and the Armenians (1220-1335) (Boston: Brill, 2011), 16-17.

${ }^{3}$ Kirakos of Ganjak, History of the Armenians, trans. John Andrew Boyle, "Kirakos of Ganjak on the Mongols," Central Asiatic Journal, Vol. 3, No. 3, (1963).
} 
perspective. ${ }^{4}$ Kirakos was captured along with his teacher Vanakan Vardapet by the Mongol commander Molar in Lorut, while taking shelter from the Mongol slaughter in Khwarazm. The Mongols pressed Kirakos into their service as a secretary; he wrote and read letters for the Mongol commanders in the summer of 1236, gaining invaluable insight into the Mongol ways. ${ }^{5}$ Vardan Arewelci (ca. 1200-1271) was also a pupil of Vanakan Vardapet and wrote during the same period. ${ }^{6}$ The works of Vardan and Kirakos often reinforced one another. Vardan's work, the Hawakumn Patmutean (Historical Compilation) was written as a chronicle, telling the history of the world from the time of the Biblical Genesis to 1267 . Vardan provided a unique Armenian perspective in that he discussed clerical attitudes toward the Mongol invasion, ${ }^{7}$ and Vardan went to see Hülegü Khan in 1264 and was received with honor. ${ }^{8}$

Although not directly quoted in the thesis, there were numerous other contemporary Armenian sources that were helpful in researching the period. These sources and authors included the Annuals written by Sebastatsi; ${ }^{9}$ the Patmutiwn Nahangin Sisakan (the History of the Siwnik' Province) written by Stepannos Orbelian $(1250 / 60-1304) ;{ }^{10}$ the works of Hetum Patmich (Hetum the Historian), also known as Hayton; the fourteenth century work of Nerses Palients; ${ }^{11}$ the Armenian Colophons; ${ }^{12}$ and

\footnotetext{
${ }^{4}$ More specifically Kirakos gives accounts of the crushing of Georgian forces in 1220/21; the submission of Cilician Armenian King Hetum I; Hetum I's campaigns into Syria; the Mongol sacking of Baghdad; the agreement between the Mongols and Armenians, see Dashdondog, the Armenians, 11-14.

${ }^{5}$ Kirakos also interacted with Greater Armenian nobles, including Pros Xalbakean, who participated in the Mongol conquest of Baghdad in 1258, and Grigor Mamikoriean, who told him about Chinggis Khan, see Robert Gregory Bedrosian, Turco-Mongol Invasions and the Lords of Armenia in the $13^{\text {th }}$ and $14^{\text {th }}$ Centuries (Ann Arbor, MI: University Microfilms International, 1979), 25.

${ }^{6}$ Vardan Arewelci, The Historical Compilation, trans. Robert W. Thomson (Washington D.C., Dumbarton Oaks Research Library and Collection, 1989), 127.

${ }^{7}$ Dashdondog, the Armenians, 14-15.

${ }^{8}$ Bedrosian, Turco-Mongol Invasions, 29.

${ }^{9}$ Dashdondog, the Armenians, 19.

${ }^{10}$ Ibid. 17-18.

11 Dashdondog, the Armenians, 25.
} 
The Anonymous Chronicle in the Georgian History of Kartli. ${ }^{13}$ All of these sources were helpful in gaining context for Armenia, Georgia, and Anatolia during the period under study.

\section{Persian Sources}

The most important source for the history of the Mongol conquest of Persia was the work of Ala al-Din Ata Malik Juwayni (1226-83), called the Tarikh-i Jahan Gusha (History of the World Conqueror), completed circa $1260 .{ }^{14}$ Juwayni was a leading member of Hülegü's administration and was an eyewitness to many of the important events during Hülegü's reign. ${ }^{15}$ He helped to establish the new Mongol capital at Maragheh and witnessed the destruction of the Ismailis (Assassins). Hülegü appointed Juwayni the governor of Baghdad after its conquest in $1258 .{ }^{16}$ Juwayni's history was quite different from others of the period because his perspective was from one who lived and worked under established Mongol rule in Persia, whereas many other authors experienced the Mongol invasions.

The most important work for the late Ilkhanid period was Rashid al-Din's (12741318) Sucessors of Genghis Khan. ${ }^{17}$ Rashid al-Din was the Grand Vizier of Ghazan and

\footnotetext{
${ }^{12}$ Colophons were writings usually found at the end of a manuscript and were most often made by the manuscript's copyist or recipient. They contained information such as the copyist's name, the year the manuscript was copied, and the year the colophon was made. They could also contain lengthy addenda on political and military developments, taxation, agriculture, and the conditions of the villages, towns, monasteries, and churches in the region, see Bedrosian, Turco-Mongol Invasions, 51.

${ }^{13}$ Bedrosian, Turco-Mongol Invasions, 57.

${ }^{14}$ Ala-ad-Din Ata-Malik Juwayni, The History of the World Conqueror, trans. John Andrew Boyle (Cambridge, MA: Harvard University Press), 1958.

${ }^{15}$ George Lane, Early Mongol rule in the thirteenth century Iran: a Persian Renaissance (New York: RoutledgeCurzon, 2003), 3.

${ }^{16}$ Dashdondog, the Armenians, 28.

${ }^{17}$ Rashid al-Din, The Sucessors of Genghis Khan, trans. John Andrew Boyle (New York: Columbia University Press, 1971).
} 
accompanied Ghazan on his last expedition, 1302-03, against the Mamluks. ${ }^{18}$ Several other helpful sources that were utilized included Khwaja Nasir al-Din Tusi's (1201-74) ${ }^{19}$ Zij al-Ilkhani (Ilkanic Tables) and Minhaj al-Din Saraj Juzjani's the Nasiri Tables. ${ }^{20}$ Tusi provided a factual unembellished account of the fall of Baghdad in 1258, in which he took part and he was a financial adviser to both Hülegü Khan and Abaqa Khan. ${ }^{21}$ Juzjani's work covered the first stage of the Mongols' conquest of Armenia and had been a witness to this Mongol conquest. Both Juzjani and Juwayni recounted some of the same events, which gave credence to both.

Although not directly quoted in the thesis, there were numerous other contemporary Persian sources that were helpful in researching the period. These sources included Abdallah ibn Fazlallah of Shiraz's (also known as Wassaf) ${ }^{22}$ Tarikh-i Wassaf (The History of Wassaf); Abu al-Qasem Abdollah Qashani's Tarikh-i Öljeitü (The History of Öljeitü); ${ }^{23}$ Hamd Allah Mustawfi Qazini's Tarikh-i Guzida (the Selected History) and the Nazhat al-Qulub (Pleasure of the Hearts); and the works of Shams alDin Ahmad al-Aflaki. ${ }^{24}$ All of these sources provided helpful contextual information on Persia during the time period under study.

\footnotetext{
${ }^{18}$ Rashid-al Din, The Successors of Genghis Khan, 4.

${ }^{19}$ Ibid. 6, 8 .

${ }^{20}$ Lane, Persian Renaissance, 3.

${ }^{21}$ Ibid. 8.

22 Ibid. 6-7.

${ }^{23}$ Ibid. 6-7.

${ }^{24}$ Ibid. 7.
} 


\section{Arabic Sources}

The most important primary source found in a complete English translation was Ibn al-Athir's (1160-1233) al-Kamil fil-tarikh (Complete History). ${ }^{25}$ Al-Athir relied on second hand accounts of refugees from the Mongol conquests ${ }^{26}$ and his work contained information relating to the Mongols in Syria. The other Arabic primary sources were found in English through secondary sources. One such example was Baybars alMansuri's (d. 1324-25) Kitab al-Tuhfa al-mulukiyya fil-dawla al-Turkiyya, ${ }^{27}$ a chronicle of the Mamluk sultans from their beginning (c. 1250) to 1311-12. Al-Mansuri served the Sultans Mansur Sayf al-Din Qalawun al-Alfi and al-Nasir Muhammad, during whose first two reigns al-Mansuri held the great office of dawadar (executive secretary). By 1312 alMansuri was appointed vice regent in Egypt, the highest appointed office in the Sultanate. The extant pieces of al-Jazari's (d. 1338) work, Hawadith al-zaman, ${ }^{28}$ provided pertainent information on the Mongols through the lens of a Mamluk author, while preserving the observations of earlier Mamluk authors.

Although not directly quoted in the thesis, there were numerous other contemporary Arabic sources that were helpful in researching the period. These sources included Sayf al-Din Abu Bakr ibn al-Dawadari's Kanz al-Durar wa-Jami al-Ghurar (the Treasure of Pearls and Trove of the Radiant); ${ }^{29}$ Shihab al-Din Ahmad al-Nuwayri's

\footnotetext{
${ }^{25}$ Ibn al-Athir, Al-Kamil fil-tarikh, Part 3, The Years 589-629/1193-1231, The Ayyubids after Saladin and the Mongol Menace, trans. D.S. Richards (Aldershot: Ashgate Publishing Limited, 2008).

${ }^{26}$ Lane, Persian Renaissance, 177.

${ }^{27}$ P. M. Holt, "Literary Offerings: a genre of courtly literature," ed. Thomas Philipp, Ulrich Haarmann, The Mamluks in Egyptian politics and society (Cambridge: Cambridge University Press, 1998), 4.

${ }^{28}$ Amitai-Preiss, Mamluk-Ilkhanid War, 5.

${ }^{29}$ No English translation available.
} 
Nihayat al-Arab fi Funun al-Adab (All That Can be Desired in the Scribal Arts); ${ }^{30} \mathrm{Ibn}$ Fadl Allah al-Umari's Masalik al-Absar fi Mamalik al-Amsar (Paths of Discernment into the Kingdoms of the Lands); ${ }^{31}$ Shams al-din Ibrahim b. Abd al-Rahman al-Qaysarani's alNur al-laih wal-durr al-sadih fi stifa mawlana al-sultan al-Malik al-Salih; ${ }^{32}$ Abul-Fida's (d. 1332) Kitab al-Mukhtasar (Compendious Book), ${ }^{33}$ and Taqi al-Din Ahmad alMaqrizi's comprehensive history of Egypt.

Yet another helpful source was the work of Ibn Abd al-Zathir (1233-1293), who was a biographer of Sultan al-Zathir Rukn al-Din Baybars al-Bunduqdari and wrote the al-Rwad al-zahir fi sirat al-Malik al-Zathir. This work was of importance for its coverage of Baybars's role at the battle of Ayn Jalut in $1260 .{ }^{34}$ Shafi b. Ali al-Asqalani (d. 1330), the nephew of Ibn Abd al-Zathir, also wrote a biography of Baybars Bunduqdari (after Baybars's death) called the Husn al-manaqib al-sirriyya al-muntazaa min al-sira alZahiriyya. ${ }^{35}$ All of these sources provided helpful contextual information on Egypt and Syria on the period under study.

\section{Other Language Sources}

The works of Bar Hebraeus, the Political History of the World and the Chronology of Gregory Abu al-Faraj, both in Syriac, were consulted in depth. ${ }^{36}$ Both works were utilized in full English translation. Bar Hebraeus's history of the early

\footnotetext{
${ }^{30}$ No English translation available.

${ }^{31}$ No English translation available.

${ }^{32}$ The exact translation of the title could not be found, but the work certainly concerns the reign of the Ayyubid sultan al-Malik al-Salih, who ruled Egypt from 1240 to 1249, see Holt, "Literary Offerings," 7-8. ${ }^{33}$ Dashdondog, the Armenians, 29.

${ }^{34}$ This work was basically a biography of Baybars al-Bunduqdari, see Broadbridge, Kingship \& Ideology, 266.

${ }^{35}$ Holt, "Literary Offerings," 5.

${ }^{36}$ Dashdondog, the Armenians, 30.
} 
Ilkhans, found in the Political History of the World, was often based on his own experiences and he was allowed access to the Ilkhan's libraries in Maragheh and Tabriz. The Chronology of Gregory Abu al-Faraj aided in comparing Syriac Christian to Armenian Christian sources, which shed light on Mongol-Christian and Christian-Muslim relations. 


\section{THE PRELIMINARY HISTORICAL NARRATIVE}

As this study revolves around the Mongols in Persia, a cursory understanding of the Mongols and their move into Persia is needed. The Mongols first emerged on the world stage under the unifying leadership of Chinggis Khan (1167-1227), known to many Western audiences as Genghis Khan, in the beginning of the thirteenth century. After his unification of the Central Asian nomadic tribes and his conquest of the Xi Xia, Chinggis Khan wished to establish trade between his lands and Persia. To this end he sent an ambassador to Sultan Mahamad of Persia along with a train of 400 merchants to buy wares in Persia. Unfortuntately, the Sultan murdered the Mongol ambassadors and merchants, which incited Chinggis's great anger and brought war upon the Khwarazm Empire, which constituted much of Iran and Afghanistan and all of Transoxiana. ${ }^{37}$ Chinggis succeeded in defeating the Khwarazm Empire, sacking its capital Samarqand, by 1220 .

The Mongols' first campaign into Persia (1219-1221) and the Caucasus caused great destruction with many cities sacked; thousands were killed; and infrastructure, including the vital irrigation systems, was destroyed. The Mongols left few forces to maintain control of Persia and the Caucasus, as most of the army was needed to confront the Chinese kingdoms. The small force that was left was led by the Mongol generals

\footnotetext{
${ }^{37}$ Ibn al-Athir, Al-Kämil fil-tarikh, quoted from Robert Irwin, The Middle East in the Middle Ages: The Early Mamluk Sultanate 1250-1382 (Carbondale: Southern Illinois University Press, 1986), 13.
} 
Chormaghan, Eljigidei, and Baiju, ${ }^{38}$ and it was they who later complained to the Great Khan Möngke (r. 1252-1259) concerning the Ismailis (Assassins) and Caliphate aggressions. ${ }^{39}$ It was not until 1257 that the Mongols sought to consolidate their power in the Middle East. The Great Khan Möngke commanded his brother Hülegü to go west with a great army to subdue those lands once under the control of the Mongols by defeating the troublesome Ismailis and the Caliph of Baghdad. ${ }^{40}$ Hülegü set out in 1257 but did not arrive in Persia until 1259.

The Mongols only completed their conquest of Armenia after three campaigns from 1239 to $1244 .^{41}$ The Mongols richly rewarded those who submitted (this acted as an inducement to the hesitant) while simultaneously devastating the lands of those who still resisted. ${ }^{42}$ According to Grigor of Akner, Chinggis Khan allegedly said to his commander Chormaghan: "It is the will of God that we take the earth and maintain order, and impose the (y)asax, that they abide by our command and give us $t z \gamma u$, mal, tayar, and $y p c u r$. Those, however, who do not submit to our command or give us tribute, slay them and destroy their place, so that the others who hear and see should fear and not act thus." This was the policy set forth in dealing with resistors and only a handful of Armenian princes were brave or foolish enough to attempt resistance.

The other area of Armenian rule that was greatly affected by the Mongols was the kingdom of Cilician Armenia, which was located on the southern coast of Anatolia near

\footnotetext{
${ }^{38}$ Reuven Amitai-Preiss, Mongols and Mamluks: The Mamluk-llkhanid War, 1260-81 (Cambridge: Cambridge University Press, 1995), 9.

${ }^{39}$ Dashdondog, the Armenians, 122.

${ }^{40}$ Concurrently, the Great Khan Möngke also commanded another brother Kublai to consolidate the Chinese lands to the east. Kublai did so, establishing the Mongol (Yuan) dynasty in China.

${ }^{41}$ The first Mongol campaign took Ani and Kars in 1239, the second took Karin in 1242, and the third with the defeat of the Seljuk Sultan in 1244, see A.E. Redgate, The Armenians (Oxford: Blackwell Publishers, 1998), 259.

${ }^{42}$ Bedrosian, Turco-Mongol Invasions, 174.

${ }^{43}$ Grigor, Nation of Archers, 301.
} 
the northern border of Syria. ${ }^{44}$ The kingdom of Cilician Armenia's relationship with the Mongols began when its king, Hetum I, had the foresight to surrender to the Mongols before they threatened his lands: "Then the pious and Christ-crowned King of Armenia, Hetum...taking counsel, came to the decision to submit to the Tatars [Mongols] and give them tribute and xalan so as not to let them into their own God-created and Christ-formed country."45

Hetum I further showed his allegiance to the Great Khan by handing over the royal family of the Sultan of Rum, who had sought refuge at Hetum's court from the Mongols. ${ }^{46}$ For his actions, Hetum was allowed to keep his kingdom and was given vassal status, in which he had to supply the Mongols with troops and supplies at any moment, pay taxes, and maintain loyalty. In return, the Mongols promised military protection against Armenia's Muslim neighbors. ${ }^{47}$

Surprisingly, the Egyptian Mamluks owed their very existence to the Mongols. As the Mongols grew in power they swept west across the Eurasian steppe, pushing other weaker nomadic tribes still farther west until they reached the Near East, the Black Sea region, and the eastern edge of Europe. One such group, the Kipchak Turks, were enslaved and bought by eager Egyptian buyers, who needed large numbers of fearsome warriors, which they called mamluks. The Mongol invasions of the 1220s and 1230s created a plentiful slave population from the many refugees. ${ }^{48}$

\footnotetext{
${ }^{44}$ Edmond Schutz, "Armenia: A Christian Enclave in the lslamic Near East in the Middle Ages," ed. Michael Gervers, Ramzi Jibran Bikhazi, Conversion and continuity: indigenous Christian communities in Islamic lands, eighth to eighteenth centuries (Toronto: Pontifical Institute of Medieval Studies, 1990), 22526.

${ }^{45}$ Grigor, Nation of Archers, 309.

${ }^{46}$ Dashdondog, the Armenians, 80.

${ }^{47}$ Ibid. 80.

${ }^{48}$ Irwin, The Early Mamluk Sultanate, 17-18.
} 
Mamluks could come from almost any people, but the Turks were prized and sought after because of what contemporaries saw as their inherent military quality. The Turks, like the Mongols, were a nomadic people where violence was part of daily life. Nomads often raided the herds of livestock and horses of other tribes and imprisoned those they defeated in battle to be sold as slaves. Turks often sold other Turks acquired through war or, during times of famine and hardship, families sold their children. ${ }^{49}$

Both Mamluks and Mongols were military elites of the Eurasian steppe who ruled over large Muslim populations and based their armies on disciplined masses of mounted archers. The Mamluks took up a sedentary lifestyle once they began ruling in Egypt and functioned as an urban military class. They stayed connected to their nomadic heritage through their continual purchasing of slaves from the Black Sea, especially from the Kipchak tribe. Once the Kipchak slaves were brought to Egypt they were trained to become mamluks, the Islamic faith's most ardent supporters and holy warriors. ${ }^{50}$

During the reign of the Mamluks in Egypt, enslavement as a mamluk was seen as a step toward acquiring power and position within the Sultanate. ${ }^{51}$ It was a respected position that was given great responsibilities and power. Often times, mamluk regiments constituted the sultan's royal bodyguard. ${ }^{52}$ Mamluks were first and foremost military slaves, but they could also perform ceremonial or administrative tasks. Mamluks served as cupbearers, equerries, and falconers, but also provincial governors, major-domos of the royal household or treasurers. The slavery of the mamluks allowed them to develop their martial skills, especially with time consuming and difficult skills such as horse

\footnotetext{
${ }^{49}$ Ibid. 5.

${ }^{50}$ Ibid. 18

${ }^{51}$ Ibid. 4.

${ }^{52}$ Irwin, The Early Mamluk Sultanate, 4-5.
} 
archery. In addition, it enabled the establishment of loyalty due from the mamluk to his master/owner, or ustadh. A mamluk was often taught other skills beyond the martial. They were often taught to speak Arabic and sometimes taught to read and write Arabic as well $^{53}$

In 1240, Sultan Al-Salih Ayyub created a new elite corps of mamluks, called the Bahriyya, ${ }^{54}$ comprised mainly of Kipchak mamluks. Al-Salih relied heavily on the military advice of his Bahriyya amirs (chieftain/commander), not trusting in his Ayyubid dynastic family, which had ruled Egypt since 1174. Al-Salih died in 1249 amidst a great military crisis and subsequent political wars followed. ${ }^{55}$ From this power struggle it became clear that the Bahri mamluks were more powerful than previously thought, but it was the threat of the Mongols that finally thrust the Bahri to the throne in 1250 .

The history of the Egyptian Sultanate from 1249 to 1259 was one of complex political maneuverings and murders. Powerful amirs, Ayyubid princes, and Bahri mamluks used young Ayyubid princes as figureheads on the throne, while they fought amongst themselves. Al-Muizz Aybak claimed the throne in 1257, but was murdered soon after. His young son, the fifteen year old al-Mansur Nur al-Din Ali, was put on the throne to keep up the façade of legitimacy. Ultimately it was Al-Muizz Aybak's most favored mamluk, Qutuz al-Muizzi, who gained power. ${ }^{56}$ Qutuz took direct control of the throne in 1259 soon after hearing that the Mongols had entered Syria. ${ }^{57}$

\footnotetext{
53 Ibid. 4-5.

${ }^{54}$ The title of 'Bahriyya' refers to where this corps was garrisoned; on the island of Rawda on the River Nile (Bahr al-Nil) outside of Cairo, see Irwin, The Early Mamluk Sultanate, 18.

${ }^{55}$ The Ayyubid prince of Aleppo, al-Nasir Yusuf, occupied Damascus and would later play a prominent role in Ayyubid/Mamluk/Mongol relations, see Irwin, Early Mamluk Sultanate, 22.

${ }^{56}$ Irwin, The Early Mamluk Sultanate, 28-29.

${ }^{57}$ Ibid. 32-33.
} 
The Mamluks came into direct contact with the kingdom of Cilician Armenia as a result of the Mongols; the Armenians were military allies of the Mongols during the long Ilkhanid-Mamluk conflict. Armenian incursions into northern Syria against the Mamluks were unsuccessful and the Mamluks sought to exact vengeance against the Armenians for their foolish raids. The Mamluks sent multiple raids into Cilicia, devastated the land and ultimately forced the Armenians to accept a greatly disadvantageous peace in 1285 . The Mamluks ultimately brought the Cilician Armenians under heel in 1375, when they captured the Cilician royal family and the capital of Sis. 


\section{THE SECOND MONGOL INVASION OF PERSIA}

Möngke of the Toluid family was elected Great Khan in 1252; among his first acts was to enact a new expansionist phase for the Empire, both by consolidating previously held lands and conquering new areas. Möngke assigned one of his brothers, Hülegü, to reconquer the lands of Iran and the southern Caucasus. Rashid al-Din described: "To conquer the lands of the enemies... until you have many summer and winter camps." 58 Reuven Amitai-Preiss further described Hülegü's charge: “To enact the laws of Chinggis Khan in the lands from the River Oxus (Jayhun) up to the edge of the land of Egypt." ${ }^{, 59}$ Hülegü was then given instructions to carry on further conquests of new lands as he saw fit; Syria was certainly a goal and the primary sources hint that Egypt was within the sights of the Great Khan. ${ }^{60}$

Hülegü's mission first dictated that before he could conquer new lands, he had to deal with the rebellious elements within the Mongols' realm. Mongol commanders in Iran had sent complaints to the Great Khan concerning attacks from the Ismailis (Assassins) and mountain rebels and the increased aggressiveness of the Caliph of Baghdad. Therefore, Hülegü's first task was to eliminate the Ismailis concentrated in eastern Iran and south of the Caspian Sea. The second task was to put down the rebellious Kurds and Lurs and the third was to render the submission of the Caliph. ${ }^{61}$

\footnotetext{
${ }^{58}$ Rashid al-Din, Successors, quoted in Amitai-Preiss, Mamluk-Ilkhanid War, 12.

${ }^{59}$ Amitai-Preiss, Mamluk-Ilkhanid War, 12.

${ }^{60}$ Ibid. 13.

${ }^{61}$ Ibid. 12.
} 
Hülegü left his ordu (camp) in February 1254 for the Middle East, arriving outside Samarqand in September $1255 .^{62}$ As Hülegü's army marched across the Middle East, he made appeals to the various local and regional rulers to offer submission to him as a representative of the Great Khan. He also demanded that they prepare for his arrival into their lands and be able to provide for his army. This type of material support was expected of any group who became vassals of the Mongols. Juwayni described the process through which the Mongols made demands of their vassals:

...The emirs and local rulers, whoever they were, began to prepare provisions ( $u l u f a$ ) and get together tuzghu or offerings of food; and they set down their offerings at every stage [of the army's advance]. At the same time the Mongol and Moslem emirs brought herds of mares and each in turn manufactured qumiz until the troops passed on to another emir. And the route along which it was calculated that the World-King would pass was cleared... and bridges were built over the rivers and streams and boats held in readiness at the ferries. ${ }^{63}$

As part of his demands for submission, Hülegü also demanded local leaders to provide military forces to take part in his campaign across the Middle East. Rashid al-Din explained that "when Hülegü Khan was coming to Persia the decree was issued that from each of the princely houses a prince should join him with an army to assist him..."64 Hülegü began his campaign in 1256, acquiring staunch allies in King Hetum I of Cilician Armenia and the Greater Armenian lords under the Georgian King David VII Ulu ( $r$. 1247-1270). ${ }^{65}$ The Armenians would remain the Mongols' strongest allies throughout Hülegü's campaign. The Armenians and Georgians had supported the Mongols in their

${ }^{62}$ Lane, Persian Renaissance, 20.

63 Juwayni, The History of the World Conqueror, 607-610.

${ }^{64}$ Rashid al-Din, Successors, 104.

${ }^{65}$ Dashdondog, the Armenians, 96, 119. 
past campaigns, particularly against the Sultanate of Rum, and they could be counted upon to provide forces again.

Local allies were also needed because the Mongol force was too small to accomplish its goals alone. It was standard practice to use local forces as a significant portion of the Mongols' forces in any given area. Local forces were often led by small Mongol contingents as was the case in much of the Persian theater of operations. Juwayni related how Mongol forces were used in Persia: "The World-King's forces encamped in the district of Talaqan and he ordered the armies of Kerman and Yezd to besiege the local castles such as Aluh-Nishin, Mansuriya and several others; and he strengthened the hand of these troops with a force of Mongols who were their mainstay (muavval)." went on to list numerous local Persian leaders who joined Hülegü in his campaign to retake the Middle East in 1260:

When the Royal banners had passed through that region the Supreme Minister (sahib-i-azam) Masud Beg and the emirs of Transoxiana joined his [Hülegü's] train...Muhammad [Shams-ad-Din Muhammad, founder of the Kart dynasty of Herat], son of Miqdat, came toward to welcome the King in advance of all his peers and equals and was distinguished amongst mankind by many marks of favor and honor... [Upon reaching Kish] the emir Arghun and most of the chief men of Khorasan reached them and offered their presents. ${ }^{67}$

Many of these Persian leaders were Ayyubid princes, of the Ayyubid dynastic family in Egypt, which the Mamluks deposed. This was also true in Syria, where the Mongols and Mamluks contended for power. These princes remained strong in their localized areas and could prove to be valuable allies for the Mongols (and the Mamluks). The most important Ayyubid rulers for the Mongols were those who ruled in Syria. On the eve of

\footnotetext{
${ }^{66}$ Juwayni, World Conqueror, 626.

${ }^{67}$ Ibid. 612-13.
} 
the Mongol invasion, Syria was split among three Ayyubid princes: al-Nasir Yusuf b. alAziz Muhammad, ruler of Aleppo and Damascus; al-Mansur Muhammad b. al-Muzaffar Mahmud, ruler of Hama; and Al-Mughith Umar b. al-Adil Abu Bakr b. al-Kamil Muhammad, ruler of Karak . ${ }^{68}$

The Mongols were only partially successful in gaining the service of these three strong princes. Al-Nasir Yusuf b. al-Aziz Muhammad, ruler of Aleppo and Damascus, vacillated between supporting the Mongols and Mamluks, ultimately to his great detriment. $^{69}$ Al-Mansur Muhammad b. al-Muzaffar Mahmud, ruler of Hama, had been on the Mamluk side since the Mongol invasion and he was rewarded by the Mamluks by receiving his kingdom again and the lands of Maarrat al-Numan and Barin. ${ }^{70}$ Al-Mughith Umar b. al-Adil Abu Bakr b. al-Kamil Muhammad supported the Mongols in his capacity as the ruler of Karak. Other Muslim rulers who aided the Mongols included Badr al-Lulu of Mosul, Al-Said Hasan of Banias, and many others. ${ }^{71}$ Prince al-Ashraf Musa b. alMansur Ibrahim of Homs marched into battle with the Mongols at Ayn Jalut, but he switched sides during the battle and his timely desertion helped defeat the Mongols. ${ }^{72}$

Once Hülegü had his armies assembled and his allies secured, he went against the fortresses of the Ismailis, who were seen as a great threat to the people of the region. The Syrian chronicler, Bar Hebraeus, described the victory of the Mongols over the Ismailis: "By means of these blessed captures God had mercy on the kings of the Arabs and Christians who lived in terror and trembling through the fear of the Ishmaelites [Ismailis]

\footnotetext{
${ }^{68}$ Amitai-Preiss, Mamluk-Ilkhanid War, 19-20.

${ }^{69}$ Yusuf had formally submitted to the Mongols before Hülegü's arrival in 1241. When Hülegú conquered Iran, Yusuf failed to show proper respect as a vassal, by failing to send gifts, troops, or even recognition to the khan. After false showings of reconciliation, Yusuf took a belligerent stance against Hülegü and sought the aid of the Mamluks.

${ }^{70}$ Amitai-Preiss, Mamluk-Ilkhanid War, 45.

${ }^{71}$ Dashdondog, the Armenians, 142.

${ }^{72}$ Amitai-Preiss, Mamluk-Ilkhanid War, 45.
} 
who were carriers of daggers and were shedders of innocent blood."73 The Muslim peoples were very keen to aid the Mongols in this pursuit and "...orders were then given for the fastening of banners and standards [to lances] and the massing of the troops for the purpose of making holy war and uprooting the castles of the Heresy. And all the forces in that region, whether Turks or Taziks, put themselves in readiness." ${ }^{, 74}$ The Armenians' first campaign alongside Hülegü occurred during the Ismailis campaign in 1256; one of their greatest achievements was the conquest of Alamut.

After his victory over the Ismailis, Hülegü marched to the city of Baghdad and called upon Caliph Mustasim to surrender the city. According to George Lane:

Hülegü was anxious to avoid further bloodshed and urged his assistant and scholar Nasir al-Din Tusi to compose a letter to the Caliph, beseeching him to see reason and to desist from his continued stubbornness. Hülegü promised good fortune and a robe of honour for the Caliph Mustasim if he should comply with the inevitable. However, Nasir al-Din Tusi's letter was rejected and the Caliph sent his response with insults and verbal abuse. $^{75}$

Vardan Arewelci wrote: "Hulawu [Hülegü] slew with his own hands the Caliph, whose name was Mustasr." 76 After the capture of the city in 1258, Hülegü executed the Caliph and secured the city. ${ }^{77}$ It should be noted that "there is little in the sources to suggest that Hülegü decided on the Caliph's fate or indeed the fate of Baghdad out of malice, a thirst for blood, or a particular penchant for violence...though Hülegü was resolute once he had

\footnotetext{
${ }^{73}$ Bar Hebraeus, Political History, quotes from Dashdondog, the Armenians, 126.

${ }_{74}^{7}$ Juwayni, World Conqueror, 615.

${ }^{75}$ Lane, Persian Renaissance, 29.

${ }^{76}$ Vardan, Compilation, 217-18.

${ }^{77}$ Hülegü's campaign continued with the sacking of Aleppo in 1260 with the aid of the Cilician Armenian king Hetum I and his son-in-law Bohemond VI, Prince of Antioch and Count of Tripoli, see M. Chahin, The Kingdom of Armenia (London: Croom Helm, 1987), 287.
} 
determined upon [the city's] destruction, it should be noted that the devastation was selective and not all were killed and not all was destroyed." 78

Once Hülegü had consolidated his gains, he officially founded the Mongol kingdom of the Ilkhanate with its center at Maragheh. Hülegü ruled this new kingdom on behalf of the Great Khan, acting as a lesser khan in the Mongol Empire. Hülegü took the title of Ilkhan, ${ }^{79}$ although there is no evidence that Möngke Khan bestowed this title on him. It is clear that the title was in use by $1259-60$ during Hülegü's reign. The origins of the title 'ilkhan' are not entirely known; the majority of scholars believe it derived from the old Turkic title, elkhan, which meant 'ruler.' Another meaning is 'subservient or submissive ruler [khan]. ${ }^{80}$

${ }^{78}$ Lane, Persian Renaissance, 28.

${ }^{79}$ Amitai-Preiss, Mamluk-Ilkhanid War, 14.

${ }^{80}$ Ibid. 14. 


\section{TERMS OF SUBMISSION TO THE MONGOLS}

The first standard Mongol procedure Hülegü enacted was the issuing of demands for surrender and submission from all of the rulers and peoples he encountered. The demand for surrender was simple and can be seen in numerous primary sources. One such example was when the Mongol military commander Aslan made an appeal to the Armenian lord Elikum Orbelian to surrender. According to Bedrosian, Vardan Arewelci related Aslan's offer: "Make friends with us [the Mongols]; come to us, and you will find many benefits from us. Otherwise, no matter how long you sit on your rock [in his fortress], we shall not quit this land. For God has given us this [land] as patrimony, and when you come forth, it will be the ruin of you and your tun [House]." ${ }^{81}$ Faced with the real possibility of destruction, Elikum subsequently surrendered. Many lords found Mongol demands to be palatable compared to the alternative: death.

Mongol terms of submission generally included the following: war service in the khan's armies; supplying the Mongol armies; extraction of taxes from the subjugated people; submission must be given in person to the Great Khan in Karakorum; the subjugated people must be obedient in all ways to the Mongols. Those princes and lords who submitted made visits to Hülegü at Maragheh in 1258, including vassals from Mosul, Fars, Rum, and Caucasia. ${ }^{82}$ According to Bedrosian, Kirakos related the surrender of the Armenian prince Hasan Jalal: "the [Mongols] ...ordered him to come to them each

\footnotetext{
${ }^{81}$ Vardan, Compilation, quoted from Bedrosian, Turco-Mongol Invasions, 176.

${ }^{82}$ Dashdondog, the Armenians, 135.
} 
year for war service, and ingenuously to be obedient to them." ${ }^{83}$ Kirakos then related the terms of Hasan Jalal's surrender; in return for Hasan Jalal's submission, Hülegü “honored him and gave him back his land and other lands besides..."

Upon surrender, the Mongols often treated their enemies with clemency. An analysis of the treatment of the Islamic ruler, Rukn ad-Din, shows that even after engaging in open hostilities with the Mongols, he was able to surrender and was treated well by Hülegü:

And he [Hülegü] again sent elchis [messengers] in advance to say that he had put into effect his intention to move forward against Rukn-ad-Din. The latter had added to his former crimes hollow excuses and feeble evasions but if he would make his heart sincere again and come forward to meet the King, he would read the lesson: 'What is past is past' over his crimes, and cast the glance of forgiveness and condonation upon his offenses, and show the teeth of assent in the face of his requests. ${ }^{85}$

The Mongols also showed favor to their vassals through marriage. But these links were not used to create any sense of equality between the Mongols and their vassals; rather, the Mongols used these marriage links to further control their vassals and increase their indebtedness. This inequality can be seen in the treatment of Rukn-ad-Din. Once he submitted, all of his possessions were placed under Mongol control; his army was divided up among the emirs and he had to accompany Hülegü to the royal ordu in the region of Hamadan. Hülegü sent elchis to fetch the remaining enemy commanders, assess the treasuries in the captured castles and guard the enemy castles until larger Mongol forces could arrive. According to Juwayni: "As for Rukn-ad-Din he was viewed with attention and kindness by the King... at the King's command, [a Mongol wife] was bestowed upon

\footnotetext{
${ }^{83}$ Kirakos, the Armenians, Bedrosian, Turco-Mongol Invasions, 176.

${ }^{84}$ Ibid. 176.

${ }^{85}$ Juwayni, World Conqueror, 618-19.
} 
[Rukn-ad-Din]...After the consummation of his marriage he asked the King to send him to the Court of Mengü Qaan [Möngke Khan]. The King approved his request...,"86 The vassal still had to pay respects to the Great Khan, despite being highly honored with a wife.

In addition to traveling to the Great Khan to offer formal submission, those surrendering had to offer royal hostages; one can see this standard Mongolian practice through both Armenian and Persian examples. After battle between the Mongols and the Persian noble Rukn-ad-Din, he finally decided to submit:

[Rukn-ad-Din] sent out his son, his only one, and another brother called Iran-Shah with a delegation of notables, officials, and leaders of his people; while on Sunday the $29^{\text {th }}$ of Shavval $\left[19^{\text {th }}\right.$ of November] he came in person before the World-King and had the good fortune of waiting upon him. He brought all of his family and dependents (muttasilan) out of Maimun-Diz and offered his treasures as a token of his allegiance. ${ }^{87}$

Another example comes from the voluntary submission of the Cilician Armenians; King Hetum I sent his brother Smbat to Karakorum to offer formal submission. Even though Smbat was received graciously by Möngke Khan, the Great Khan still demanded that the king himself come and visit him, which he did.

\footnotetext{
${ }^{86}$ Juwayni, World Conqueror, 723.

${ }^{87}$ Ibid. 717.
} 


\section{THE DIVINE MANDATE AND ITS IMPACT ON RELATIONS}

It is both pertinent and important to analyze the Mongols' idea of the Divine Mandate and how it shaped foreign relations. The Divine Mandate was the single most important factor in shaping the relations between the Mongols and the peoples they encountered, as it established framework that formed all relations. To understand this framework, one must first understand the Divine Mandate, which began with the birth story of the Mongols. Kirakos of Ganjak related this origin story as told to him:

...[The Mongols'] king was related to God, God having taken the heavens as His share and given the earth to the Xayan, was not born of the seed of man, but a light came from the unseen and entered through the skylight of the house and said to his mother: "Conceive and thou shalt give birth to a son [who shall be] emperor of the earth...' This was told us by Grigor the isxan [prince]... who had heard it from a great man amongst the great commanders, whose name was rutun Nuin, one day when he was instructing young children. ${ }^{88}$

The heavenly child was Temujin, who later acquired the honorific Chinggis Khan. It was his and his successors' destiny to rule over all of the peoples of the world.

Some scholars debate over whether the Divine Mandate existed or not and whether Chinggis believed in it. David Morgan argues against the existence of the Divine Mandate during Chinggis's reign, but Reuven Amitai-Preiss argues that it was clear Chinggis's successors did believe in it:

It might be mentioned that Temuchin's adoption of the title Chinggis Khan, which has been translated as 'Oceanic' or 'Universal Khan,' may be

${ }^{88}$ Kirakos, the Armenians, 203. 
an indication that some form of this ideology was current in his lifetime. Be this as it may, it is important to note that the 'imperial idea' was later to find repeated expression in the context of the Mamluk-Ilkhanid war. As will be seen, this belief is found to varying degrees in the many missives sent to the Mamluk rulers from 1260 onward. [Reuven] would suggest that it was one of the reasons behind the ongoing war with the Mamluks... ${ }^{89}$

This viewpoint seemed the most plausible based on the primary evidence. There were several examples of the Ilkhans using the Mongol origin story as ruling justification in their diplomatic letters to other peoples. According to Amitai-Preiss there was an example from the writings of Rashid al-Din, who said that after the battle of Abulustayn in 1277: "Abaqa [Khan] wrote to [the Mamluk Sultan] Baybars, and inter alia declared that God had given the earth to Chinggis Khan and his descendants." 90

There was also numismatic evidence that points to the Ilkhans' belief in the Divine Mandate concept. These statements of global imperial rule were stamped on coins manufactured in the Ilkhanate during several different reigns. On some of Abaqa Khan's coins (the second Ilkhan) one finds such titles as: 'lord of the world (padishah-i alam)' and 'ruler of the necks of the nations (malik riqab al-umam), ${ }^{, 91}$

Additionally, it seemed that other peoples believed in some interpretation of the Divine Mandate, which can be seen in Armenian and Persian texts. It was believed that the Mongols had divine support and/or they were used as a punishment for sins. The Armenians certainly saw the Mongols as divine punishment as explained by Grigor:

Thus was accomplished what God had threatened, speaking through his prophet. '[Nebuchadnezzar of Babylon] is a cup of gold in my hand, and to whomsoever I wish I shall give to drink of it.' Thus this wild <and bestial $>$ folk not only once brought the cup, but also the dregs of bitterness upon us, because of our many and varied sins, which continually roused the anger of the Creator our God at our deeds. Wherefore the Lord roused

\footnotetext{
${ }^{89}$ Amitai-Preiss, Mamluk-Ilkhanid War, 11.

${ }^{90}$ Rashid al-Din, Successors, quoted in Amitai-Preiss, Mamluk-Ilkhanid War, 231.

${ }^{91}$ Ibid. 231.
} 
them in his anger as a lesson to us, because we had not kept his commandments. ${ }^{92}$

Grigor further related that: "The angel...named their chief Гayan, whom they called Cankez Tayan [Chinggis Khan] or Cankez Xan. The angel bade them rule over many countries and districts, and to multiply without limit and in countless numbers, which also came to pass. ${ }^{~} 93$ If an angel from God had appeared to the Mongols as Grigor described, then the Armenians must have had some concept of the Divine Mandate and its requirement for the Mongols to rule the world. In addition to prophetic writings and stories, many different peoples (usually sedentary) believed in the Chinggisid claims to divine support because these claims were underscored by the speed and success of Mongol military campaigns. According to Anne Broadbridge, only a dynasty supported by God could conquer so much so fast. These divine concepts continued from Chinggis to his successor Ogedei and helped to inspire the conquests of the $1230 \mathrm{~s}$ and $1240 \mathrm{~s}^{94}$ Broadbridge's argument appeared to be the most plausible in helping to explain how sedentary peoples may have believed in divine support to the Mongols.

The Divine Mandate shaped relations by establishing a rigid framework with the Mongols always being on top of the ruling hierarchy. Mongol decision-making was also shaped by the Divine Mandate; policies were geared toward military conquest. ${ }^{95}$ Therefore, any relationship could only be 'the conqueror and the conquered,' or as enemies.

\footnotetext{
${ }^{92}$ Grigor, Nation of Archers, 291.

${ }^{93}$ Ibid. 291.

${ }^{94}$ Anne Broadbridge, Kingship and Ideology in the Islamic and Mongol Worlds (Cambridge: Cambridge University Press, 2008), 7.

${ }^{95}$ Broadbridge, Kingship \& Ideology, 1-7.
} 
This 'conqueror or conquered' mentality can be seen in the terminology used in the primary sources:

Those who totally submitted were $e l(i l)$, which literally meant 'to be at peace or in harmony,' but really connoted the state of unconditional loyalty to the Mongols. On the other hand, all those who resisted the Mongols and refused to submit were bulgha (literally 'to be in a confused or disordered state') or yaghi ('enemy'); both terms expressed the state of being 'unsubmitted' or 'rebellious' and thus being at war with the Mongols. There was no intermediate state and those who resisted were to be annihilated accordingly. ${ }^{96}$

Even some of the primary source authors thought in this binary fashion. Grigor explained the Mongol conquest of Armenia in these terms: "When this wild <and bestial> folk [the Mongols] learned that it was the will of God to rule... upon the earth, thereupon they gathered their troops and attacked the Persians." 97

After their enemy submitted, the Mongols demanded benefits that propelled their conquests, such as the provisioning of its armies, the acquisition of more military forces, and the establishment of a loyal and stable government in the area. For a Mongol vassal, these conditions were non-negotiable: accept them or be killed. Even those standard benefits the Mongols offered to their new vassals had a military advantage built in for the Mongols. The Mongols primarily offered military protection to their new vassal and on the surface this would seem like a negative for the Mongols since it would pull Mongol forces away from future campaigns of conquest. But the Mongols needed to ensure the stability of their conquered regions so that they would remain under Mongol control and continue to supply the Ilkhan's armies with supplies and men.

\footnotetext{
${ }^{96}$ J.F. Fletcher, "The Mongols: Ecological and Social Perspective," HJAS 46 (1986): 19, 30-5, cited in Amitai-Preiss, Mamluk-Ilkhanid War, 9.

${ }^{97}$ Grigor, Nation of Archers, 291.
} 
Further concessions, such as the exemption from taxation of the Armenian Church, also helped to reestablish stability in the area, as well as gaining local support from the Church. The return of lands to the Armenian nobles also engendered loyalty and stability. Local control also meant that local troops could be used as the bulk of defensive forces (although some Mongols remained as mentioned earlier). The Mongols could then send the majority of their warriors to the front. This was of especial importance during the Mamluk-Ilkhanid conflict, as the Mongol horse archer was the most effective weapon against the Mamluks' own horse archers and heavier cavalry.

Clearly the Mongols shaped their policies and offered benefits according to their pursuit of the Divine Mandate and as such, the vast majority of benefits conferred upon their vassal would also benefit the Mongols. But how did the Divine Mandate shape and impact relations between the Mongols and the Mamluks? How could the Mongols enact a ‘conqueror's policy' when they had not yet conquered their enemy, the Mamluks? From the beginning of their relationship, the Mongols aggressively demanded the submission of the Mamluks. This stance is clearly represented in the diplomatic letters exchanged between multiple Ilkhans and the Sultans. In 1260, Hülegü sent envoys to Egypt, bringing a letter demanding submission. The letter contained verses from the Koran and was couched in Islamic terms, but the message was clearly Mongol, submit or die and the Mongols possess the divinely given right to rule the world. ${ }^{98}$

The Mongols continued to demand submission, even after their defeat at Ayn Jalut, which they viewed as a temporary setback. According to Robert Irwin, Ayn Jalut had no immediate and significant negative impact on the Mongols' war-making abilities; they were able to mount military campaigns in the following years: $1261,1280,1299$,

\footnotetext{
${ }^{98}$ Amitai-Preiss, Mamluk-Ilkhanid War, 36.
} 
1301, and 1303. ${ }^{99}$ Amitai-Preiss concurred that Ayn Jalut was only an 'interim victory' for the Mamluks. As he pointed out, the Mongol army defeated there was only a fraction of the Ilkhanate's total forces. ${ }^{100}$ Based on this evidence, it is clear that Irwin's analysis is the most plausible concerning the impact of Ayn Jalut.

Another aspect of the Divine Mandate impacted Mamluk-Ilkhanid relations much more than the demand for submission. The Divine Mandate inherently conveyed two important ideas: the first was that the Mongols were commanded by God (Tenggri) to conquer the world. If they pursued this policy, the Mongols were following the plan and will of God. Broadbridge's interpretation of the Divine Mandate stated that the Mongols were conquerors because God had commanded them to do so. Therefore, the Mongols, by their actions, were following the will of God. If anyone resisted the Mongols, they were also resisting God's will. As such, these resistors were unbelievers and must therefore be punished. Broadbridge's summation: In obedience to the will of the Enduring Sky (Tenggri), members of Chinggis's imperial or 'golden' family attempted to impose universal Chinggisid rule on the world through military campaigns. Any independent ruler intent on retaining his independence was a rebel against the golden family and the Enduring Sky. Merciless slaughter of such rebels was necessary and good, since it implemented divine will and provided an object lesson to other would-be rebels. ${ }^{101}$

The Mamluks were a shining example of being obstructors to the Mongol right to rule the world. After his conversion to Islam in 1295, the Ilkhan Ghazan (r. 1295 to 1304) sent a series of letters to the Mamluk Sultan Nasir [al-Din] Muhammad b. Qalawun (second reign 1299-1309) bragging about his own Islamic piety, but more importantly,

\footnotetext{
${ }^{99}$ Irwin, The Early Mamluk Sultanate, 34.

${ }^{100}$ Amitai-Preiss, Mamluk-Ilkhanid War, 47.

${ }^{101}$ Broadbridge, Kingship \& Ideology, 6.
} 
offering a more subtle demand for surrender. According to Thomas Raff, Ghazan considered his letter a warning to the Mamluks to surrender and his messengers were the harbingers of this warning. ${ }^{102}$ Furthermore, Ghazan displayed his commitment to the belief that the Mongols held God's favor and were doing God's will when he, according to Raff, accused the Sultan Qalawun of " 'persistence in aberration' as well as obstinacy to God and obstinacy to us [Mongols];' Nasir ad-Din's [Qalawun's] soldiers 'wage war against God,' they 'give open battle to God by acts of rebellion.' He therefore advises the Mamluks to "put the affair in (the correct!) order." ${ }^{103}$ When Ghazan referred to the correct order, he was referring to the correct world order in which the Mongols ruled the world and the Mamluks were in their rightful lowly place as slaves. The Mamluks were going against God and were considered rebels because they were interfering with God's plan to see the Mongols as the rightful rulers of the world. Clearly, Ghazan still believed and utilized all of the major aspects of the Divine Mandate, especially in his dealings with the Mamluks.

The second important concept that arose from the Divine Mandate was that a hierarchical structure existed in the world. It can also be interpreted that God established this hierarchical order since He sought to make the Mongols the rulers of the world. This sense of hierarchy was also present in the Mongols' nomadic societal structure, thus it was a concept familiar to them (as it was to most peoples during this time). The policies pursued by Chinggis Khan clearly showed the Mongols' adherence to a hierarchical system. During his conquests to unify the nomadic tribes, Chinggis instituted a policy in which defeated nomads and other Mongols were enslaved and incorporated into a

\footnotetext{
${ }^{102}$ Thomas Raff, Remarks on an Anti-Mongol Fatwa by Ibn Taimiya (Leiden, 1973), 35.

${ }^{103}$ Ibid. 35.
} 
hereditary system of slavery (ötegü boghul). The system was meant to destroy any tribal power and connections left after his conquests, as well humiliating the defeated tribes. ${ }^{104}$ This tactic was especially effective in nomadic societies because to the Mongols slavery was the condition of lesser peoples.

The Mamluks insulted and stood in the face of these two principles. The Mamluks, both in definition and practice, were a slave caste, the lowest of the low on the social hierarchy. Yet, there they stood acting in positions of authority, fighting on the battlefield in elite units, and even ruling as sultan! These facts alone were insults to the Mongols (and Armenians) as it went against everything they believed in and lived by. ${ }^{105}$ But just as importantly, the Mamluks had the audacity to openly and vehemently resist the Mongols. Now they were seen as rebels and unbelievers who could not accept God's will that they submit and be ruled by the Mongols. The Mamluks' continued resistance and victories were slowly working to prove the Divine Mandate wrong. This was surely even greater motivation for the Mongols to defeat the Mamluks.

${ }^{104}$ Broadbridge, Kingship \& Ideology, 13.

${ }^{105}$ Ibid. 13. 


\section{THE MONGOLS AND ARMENIANS}

This section will examine the primary evidence (available in English translation) relating to the interactions and links between the Ilkhanid Mongols and the kingdom of Cilician Armenia and Greater Armenia. In the instances where the word 'Armenians' is used, this is referring to all Armenians, both those from Cilicia and those from Greater Armenia. Distinctions will be made between the two groups when appropriate. This section will ultimately argue that based on the analysis of primary and secondary literature, the negative consequences of the Mongol-Armenian alliance greatly overshadowed the benefits, ultimately stating that the Armenians' alliance with the Ilkhanid Mongols was primarily detrimental to the Armenians. This conclusion flies in the face of the standard expectation that an alliance would prove mainly beneficial for the parties involved. This type of expectation certainly can apply to an alliance with the Mongols, who at the beginning of the period under study, were the most successful and powerful force in Asia and were poised for further triumphant conquests.

This section will begin with a summary of the submissions of the Armenians and an explanation of their specific terms of surrender, their status as a subject or vassal state, and the benefits a vassal could receive from the Mongols. Next, there will be an analysis of the actual benefits the Armenians received, both those they actively pursued and those conferred by the terms of submission. The focus will then shift to analyzing the negative effects the Armenians experienced from their Mongol alliance. These negative effects are 
divided into subtopics: first, those negative effects that occurred because of a failure on the Mongols' part; second, those negative effects that resulted from the Armenians seeking to fulfill Mongol demands; and third, those negative effects that resulted from the Armenians not fulfilling their obligations to the Mongols.

By the mid-thirteenth century the Mongols looked like an invincible military machine and many in their path submitted to their superior force. Such a relationship could have benefits for the vassal. After the initial shock of submission, the Armenians began to hope they would earn significant benefits from their relationship with the Mongols. For the Cilician Armenians, the very real threat of the Mongols was enough to procure their submission. Submission was seen as a wiser decision, in that the Mongols would hopefully not invade Cilician Armenia and devastate the country. Hetum I's submission had the immediate desired effect; the country was spared. But it is unclear whether Hetum really knew all of the obligations required of a Mongol vassal. If he had, would he have still chosen submission? Presumably, he would have still surrendered because the destruction of Cilician Armenia was a much more immediate and measurable consequence than the more attrition-like loss of men and resources required by the Mongols. Submission was also the best course because the Mongols were the most powerful and immediate threat to the Cilician Armenians at that time. The Cilician Armenians' neighbor, the Sultanate of Rum, had just fallen to the Mongols and the Cilician Armenians had not yet directly encountered the other powerful regional player, the Egyptian Mamluks.

The circumstances around the surrender of the princes of Greater Armenia were quite different. In this case, the nobles resisted the Mongols, but failed. Hence, this 
established a true 'conqueror, conquered' relationship. The Greater Armenian princes surrendered individually in order to preserve what little they had left. Some of the benefits of surrender were clearer immediately to the Greater Armenian princes because it was conveyed to them that if they surrendered the Mongols would return their lands to them. One such example was the Armenian Prince Vahram of Gag; when he learned of the possibility for clemency, he commanded the city of Samkor, which belonged to him, to surrender to the Mongols. In fact, he forbade the city to resist at all. ${ }^{106}$

It was clear that both the Cilician Armenians and the Greater Armenian princes had little choice in surrendering, but why did the Armenians choose to stay allied with the Mongols? Presumably, the Mongols were seen as a safer political bet than, say, the Mamluks. During this time, the Mongols looked as though they would continue their conquests; they certainly had proven their prowess by conquering Armenia, and the Armenians had certainly heard of the Mongols' other conquests. Some of the Armenians' decisions in staying allied with the Mongols can be partially explained by utilizing a phrase called 'Mongol Prestige,' which was coined by Marshall Hodgson. ${ }^{107} \mathrm{He}$ developed this phrase as one way of explaining the impact of Mongol ideology on the outside world. 'Mongol Prestige' was when non-Mongol peoples expressed awe and respect for Mongol military might. This awe then influenced the political actions of these non-Mongol peoples because they would make appeals to the greatness of Mongol military might. ${ }^{108}$ Taking 'Mongol Prestige' into account, the most plausible reason the Armenians stayed allied with the Mongols was largely because of the Mongols' military

\footnotetext{
${ }^{106}$ Bedrosian, Turco-Mongol Invasions, 172-173.

${ }^{107}$ For Marshall Hodgson's argument in full, see Broadbridge, Kingship \& Ideology, 9.

${ }^{108}$ Broadbridge, Kingship \& Ideology, 9.
} 
strength. The Armenians thought they would be protected while avoiding further Mongol devastation.

Secondly, the Mongols were the most immediate threat to the Armenians, so in order to preserve themselves, the Armenians needed to submit to the Mongols. There were no strong peoples around them to help them ward off the Mongols; no other country could really help them, especially as the Armenians helped the Mongols subdue their neighbors, i.e. Rum. Also, once the Armenians began to help the Mongols in their military campaigns in the surrounding area, they were seen as enemies by the neighboring peoples, thus burning any future possibilities for local/regional alliances.

Thirdly, Armenian religious thought played a role in continuing the Mongol alliance. The Armenians believed that it was God's will that the Armenians should be conquered by the Mongols and that the Mongols were militarily successful because they had God's favor. The Mongols' victories confirmed to the Armenians that God supported the Mongols, thus the Armenians should support God's Chosen. This belief became prominent in the Armenian literature of the period and was used to explain Mongol success and the beginning of the Armenian-Mongol alliance. Whether the viewpoint of these Armenian authors truly represented the belief of their people is unclear. It was possible that the Armenian authors used such rationale as a coping mechanism in dealing with the Mongol conquest of their country; as a way of understanding why such a catastrophic event would happen, or why God would allow such an event to happen. It is unclear if this was the case, but certainly is a viable reaction to trauma.

Either way, the Armenians showed their 'support' for the Mongols and believed they were their best bet by expressing and exalting divine favor. Grigor of Akner 
described the development of this belief in the Mongols' divine support: “... when the wise princes of Armenia and Georgia realized that God had given power and victory to [the Mongols] to take our lands, they then became reconciled, and became obedient to the Tatars..."109 The Mongols' military successes convinced the Armenians that God favored the Mongols, therefore the Armenians believed that the Mongols were the strongest power in the area. The Armenians also believed they could count on their protection. Very few people could have imagined the Mongols' defeat at Ayn Jalut at the hands of the Mamluks only a few years later. Even when seen as a punishment for their sins, it was still the safe bet to side with those chosen by God to act as his vessel, those God showed favor to.

Another form of protection the Mongols offered was their showing of support for one particular ruler in any given area. Earning the Mongols' support meant that a ruler secured his throne and had a ready made security force in times of rebellion against his rule. The Mongols' chosen ruler showed his loyalty to the Mongols by abiding by the terms of submission, but also by portraying himself as a conservative protector of Chinggisid heritage through marrying a Chinggisid princess, ruling in the name of the Chinggisids, and swearing to uphold the Yasa (the legal code of the Mongols set forth by Chinggis Khan). ${ }^{110}$

Even some Persians believed in Mongol superiority and assumed the Mongols would continue to be victorious. According to Juwayni:

The truth of God's secret intent by the rise of Chingiz-Khan has become clear and the benefit afforded by the passing of dominion and sovereignty to the World-Emperor Mengü Qa'an [Möngke Khan] plain to see. By this famous victory the keys of the lands of the world are placed ready for use

\footnotetext{
${ }^{109}$ Grigor, Nation of Archers, quoted in Bedrosian, Turco-Mongol Invasions, 177.

${ }^{110}$ Broadbridge, Kingship \& Ideology, 9.
} 
in the hands of the [Mongols'] power, and the bolts of the remaining countries of the climes... are now undone. ${ }^{111}$

\section{Benefits of Mongol Allegiance}

First and foremost, the Mongols offered military protection for their vassals. It was within Mongol interests to protect those who they had recently conquered. These conquered peoples would no longer have the capacity to defend themselves as the Mongols would have destroyed any immediate military threats. One such example can be gleaned from the Mongols' treatment of the Greater Armenian princes. The Mongols demanded that the princes destroy their mountain strongholds and then left Mongol troops in place to protect these areas while further Mongol forces were called upon to subjugate the area. According to Grigor of Akner, after the Armenian and Georgian princes surrendered to the Mongols, the Mongols ceased their destructive campaign "but they left a captain, Tara Buya (Qara Buqa) by name, to demolish all of the strongholds which had been conquered. They destroyed even to the foundations the impregnable forts built by the Arabs at a great cost. This all came to pass." 112 It was also important for the Mongols to protect the numerous assets their conquered regions provided. This need for immediate security can be seen in the case of Rukn ad-Din, who submitted to Hülegü during the Ilkhan's initial reconquest of Persia. Once Rukn ad-Din submitted, all of his possessions were placed under Mongol control; his army was divided up among Hülegü's emirs and he had to accompany the Ilkhan to the royal ordu in Hamadan. Hülegü sent elchis to fetch the remaining enemy commanders, while his Mongol forces assessed the treasuries in the captured castles, and guarded the enemy castles until larger Mongol

111 Juwayni, World Conqueror, 638.

112 Grigor, Nation of Archers, 297. 
forces could arrive. ${ }^{113}$ This proposal for immediate security in the aftermath of Mongol conquest surely seemed enticing to those who wished for the violence to end and to save what little they had left.

As a result of their administrative outlook, which placed primary emphasis on proper, loyal service above all else, the Mongols maintained an empire of religious tolerance. This was certainly seen as a benefit to the conquered peoples who were relieved that they could contiue their native religions. Within the Ilkhanate's administration, positions of power were held by Christians, Muslims, Jews, and pagans. Some of the most prominent contemporary scholars found patronage at the court of the Ilkhanate, including many authors whose works have survived to inform historians on this period. One such example was the Muslim writer Nasir al-Din Tusi, who "was quickly pardoned and honored despite his history with the hated Ismailis...Tusi was almost immediately installed in a place of honour and power in Hülegü's court... One of...[Tusi's] first tasks was the establishment of his seat of learning in Maragheh containing his famous library and observatory, a centre for an international cast of academics, clerics and scholars..."114 Bar Hebraeus also found sanctuary in Maragheh and utilized its great places of learning. ${ }^{115}$

Hülegü was keen to utilize all of the local talent he could in the running of his new empire. The biographer of Ghazan Khan, Rashid al-Din, related the treatment of his own relatives, who had honorably served the previous Persian regime. According to

\footnotetext{
${ }^{113}$ Juwayni, World Conqueror, 723.

${ }^{114}$ Lane, Persian Renaissance, 256.

115 Ibid. 256.
} 
George Lane, Rashid al-Din's “own relatives were recognized for their own abilities and were given refuge after the fall of Alamut." "16 In addition:

The thinker and Shia divine, Ibn Tawus, together with other clerics and scholars were all spared the massacres of Baghdad and like the Caucasus's leading clerics and academics, were soon co-opted into Hülegü's circle of apparent admirers....Rashid al-Din readily acknowledges Hülegü's keen interest in science and the disputations and discussions of philosophers and scholars and his generous allocation of pensions and stipends to these learned 'hangers' on," 117

Therefore, Hülegü and his successors were more concerned with utilizing the resources at hand than instituting religious or political persecution.

Service to the Mongols could also provide great political benefits to their vassals. The Mongols conferred political power to their most valued vassals by favoring certain houses over others, either through the granting of positions or the redistribution of lands from less favored vassals to the valued. In the case of Greater Armenia, political power granted from the Mongols allowed certain Armenian houses to capitalize on their positions, even after the fall of the Ilkhanate. Such an example was Prosh Khaghbakian, who strengthened the position of his house (later known as the Proshians) through his loyalty and service. ${ }^{118}$

A very valuable incentive for the Mongols' vassals was the possibility of having their lands returned to them (perhaps with some additional land). The treatment of the Greater Armenian princes gave several such examples. According to Vardan Arewelci: "Vahram with his son Ałbułay fled from place to place, until he realized that they spared

\footnotetext{
${ }^{116}$ Ibid.

${ }^{117}$ Ibid.

${ }^{118}$ Dashdondog, the Armenians, 141.
} 
those who submitted and willingly capitulated. Then he came and received the castles and the province taken from them which had been [Vahram's] own patrimonial property." "19

Bedrosian quoted Kirakos as giving the following information on Prince Awag's surrender to Chormaghan, the Mongol general for Armenian lands:

[Chormaghan] further ordered all of his troops not to fight with the fortresses and cities under Awag's domination. And great ease came about in his [Awag] land and many captives among the azats were freed because of him. And [Chormaghan] gave him all of his land and more besides and established unbreakable friendship with him. Taking Awag and all his troops, [Chormaghan] marched against the city of Ani. ${ }^{120}$

In most instances, when a prince surrendered, the Mongol commander ordered the destruction of all the prince's lands to cease immediately, thus sparing him further damage (a great benefit in itself). One can see the immediate operation of the Mongol terms of submission in Kirakos' description; Awag received his lands back and in return went on campaign with Chormaghan immediately against Ani.

Certainly the most important benefit the Mongols conferred to their vassals was the extension of a pardon for all the past transgressions the vassals had committed against the Mongols. These transgressions could be direct military opposition, simply being on the losing side, or not following Mongol demands. Kirakos again described the process of Prince Awag's submission. After his initial submission, Awag then visited the Khan in Karakorum. Many other Armenian princes were at court offering submission as well. These men included "...Sahnsah, son of Zakare; prince Vahram and his son Albula; Hasan called Jalal, prince of the Xacen area, and many others. The Tatars gave to each one control over his lands and for the time being, a pardon." ${ }^{121}$ A pardon given by the

\footnotetext{
${ }^{119}$ Vardan, Compilation, 214.

${ }^{120}$ Kirakos, the Armenians, quoted in Bedrosian, Turco-Mongol Invasions, 175.

${ }^{121}$ Ibid. 176.
} 
Khan meant that the Mongols would cease military operations against the new vassal and he would not longer be considered an enemy of the Mongols.

Of great importance to warrior aristocracies was the opportunity to gain and prove martial prowess. They did this both to secure the loyalty of their own people and earn the respect of their enemies and possible allies. The Armenians were such warriors and "the Caucasian Christians and the Armenians of Lesser Armenia [Cilician Armenia] willingly swelled the ranks of the conquering [Ilkhanid] army and were energetic in proving themselves brave and worthy allies." 122 According to Bedrosian, Grigor of Akner stated: "Hülegü Khan greatly loved the Armenian and Georgian forces because of the extreme bravery which they displayed before him in all battles. Therefore he called them bahaturs [heroes, champions]. He selected the young and handsome sons of the great princes of Armenia and Georgia and appointed them as his guards."123

Although the Greater Armenian submissions were for the most part forced by violence or the threat of violence, the Armenian princes quickly looked for what benefits they could glean from this subservient status to the Mongols. The princes' main aim was to increase their political power at the expense of other princes. This political rivalry allowed the Mongols easily to keep the Armenians and Georgian families divided. ${ }^{124}$ It was Mongol policy that before conquering a particular area, the area was always divided up to be taken by lots among their generals. The surrendered naxarars then became clients of the particular Mongol general conquering that territory. This standard Mongol policy worked well in creating and perpetuating divisions among the Armenian nobility. An example of the Mongol policy of pitting Armenian political ambitions against one

\footnotetext{
${ }^{122}$ Lane, Persian Renaissance, 258.

${ }^{123}$ Grigor, Nation of Archers, quoted in Bedrosian, Turco-Mongol Invasions, 186.

${ }^{124}$ Bedrosian, Turco-Mongol Invasions, 180.
} 
another was in the 1260 s and 1270 s, when the Mongols furthered the territorial and political ambitions of the Orbelians and the Arcrunid/Mahkanaberdelis at the expense of the Zakarids and the Georgian Bagratids. ${ }^{125}$ Obviously, the Arcrunid/Mahkanaberdelis families benefited from their Mongol alliance (but such Mongol favor vacillated).

Another way in which some Armenians benefited from their Mongol alliance was through the conquest of other Armenians. Beside the Mongols they attacked Armenian cities that had not surrendered. They received plunder and possibly land. One such example came from the Mongol conquests in the 1230 s and 1240s. It is pertinent because the Mongols pursued very similar policies in the 1250 s and the Armenian princes acted in a similar fashion:

Then the great and independent princes of Georgia... became tributary to them, willingly or unwillingly. They gave freely all of the tribute demanded... They themselves, according to their resources and ability, came with their cavalry with them (the Tatars) on raids, and took the unconquered towns and castles, plundering and taking captives. They killed without mercy men and women, priests and monks, making slaves, taking the deacons as their slaves, and plundering the churches of the Christians without fear.... ${ }^{126}$

This type of military assistance also extended to wars beyond the Armenian border. Grigor of Akner stated that a "mustering of the people of the archers with the Armenian and Georgian princes [occurred], and they attacked the country of Rum with a countless multitude."127

In reaction to the Armenian princes' efforts toward political gains, the Mongols bestowed several different benefits. These measures began after 1256, the year Hülegü founded the Ilkhanate. The Mongols attempted to incorporate certain prominent naxarars

\footnotetext{
${ }^{125}$ Ibid. 183.

${ }^{126}$ Grigor, Nation of Archers, 303-05.

${ }^{127}$ Ibid. 309.
} 
into their own court and administration. They further bound the naxarars through marriage, giving each a Mongol wife. They also granted certain Armenian territories inju status, i.e. independent authority on one's own land. This new status broke the princes away from the Georgian crown to the benefit of the Mongols and the Armenian princes, who had chomped at the bit to free themselves from the Georgian regime. Smbat Orbelian received inju status in 1252; Hasan Jalal received it in 1257; and Sarqis Jaqeli in 1273. ${ }^{128}$ Some Cilician Armenian nobles were treated in a similar fashion. Möngke Khan made "him [Smbat Sparapet] a vassal and gave him a great iarlax, a golden tablet, and a real Tatar queen with a crown, which for them was a great honor. To whomsoever they honor and esteem they give a wife from their women of station. Thus they were giving great honor to the Armenian general." ${ }^{129}$ According to Vardan Arewelci, Hülegü further trusted the Armenians by using Armenian merchants as emissaries. ${ }^{130}$

The princes of Greater Armenia and the king of Cilician Armenia both sought territorial gains, a chief desire of all rulers. According to Dashdondog, the Armenian chronicler Hetum Patmich described the following event. After the capture of Syria and Palestine in 1260, the Mongols gave King Hetum I of Cilician Armenia territory in western Cilicia along with several fortresses that had been taken by the Muslims. King Hetum I also expanded his territories on the Cappadocian, Mesopotamian, and Syrian borders where the trade routes passed and his son-in-law Bohemond VI of Antioch received the port of Latakia. ${ }^{131}$ Grigor explained that: "[Hülegü] began to rebuild the devastated places, and from each inhabited village he selected householders, one from the

\footnotetext{
${ }^{128}$ Bedrosian, Turco-Mongol Invasions, 184-185.

${ }^{129}$ Grigor, Nation of Archers, 315.

${ }^{130}$ Bedrosian, Turco-Mongol Invasions, 184-185.

${ }^{131}$ Hetum Patmich quoted in Dashdondog, the Armenians, 140.
} 
small, and two or three from the large villages, and he called them iam, and sent them to all of the destroyed places to undertake rebuilding. They paid no taxes at all, but gave only bread and broth for Tatar travelers. He established by such ordinances the throne of his Khanate..."132

Just as common as desire for land, the Armenians also sought material wealth from gaining economic routes and booty from military campaigns. The Armenian naxarars and common soldiers received booty from their Mongol campaigns. This was a large benefit for the Armenians in their alliance with the Mongols. They were especially enriched after the sacking of the Sultanate of Rum and when Awag helped sack Ani he looted its churches. ${ }^{133}$ Bedrosian supplied a passage from the Georgian chronicle the History of Kartli: "The Georgians and Tatars swelled up with all sorts of treasures: gold and silver, gold and silver cups and bowls, extraordinary cloths and clothing and so many horses, asses and camels that it is impossible to count them." 134 The Armenians also gained many religious treasures, including the right hand of Saint Bartholomew. After a siege of three years the Mongols "took the City of Martyrs [Mayyafariqin], where the Armenian forces which were with the Tatars found many relics of the saints and brought them to their country."135

Christianity played an important role in shaping Armenian-Mongol relations, both in actual events and how they interpreted later. The Armenians wanted a strong ally in protecting and promoting Christianity and it seems that they measured a ruler's value on his support of their faith:

\footnotetext{
${ }^{132}$ Grigor, Nation of Archers, 345.

${ }^{133}$ Bedrosian, Turco-Mongol Invasions, 177.

${ }^{134}$ The History of Kartli quoted in Bedrosian, Turco-Mongol Invasions, 179.

${ }^{135}$ Grigor, Nation of Archers, 335.
} 
Since they [Hetum and his advisors] had first seen Baču, the commander of the Tatar army, and had confirmed a pact of friendship and submission, then after this they sent the brother of the King, the general of Armenia, Baron Smbat to Sayin Гan [Mönkge Khan], who had been set on the throne of Cankez Tan [Chinggis Khan]. He went with the blessing of God and saw Sayin $\Gamma$ an, who was very pro-Christian and virtue-loving. Because of this his people called him Sayin $\Gamma$ an, which in their language means the good and fine $\Gamma$ an. ${ }^{136}$

A showing of support for Christianity certainly also helped in their negotiations, although in this quote Grigor flipped the situation by the Khan showing gratitude for the Armenians being Christian. "On seeing the Armenian general [Smbat], Sayin Tan [Möngke Khan] rejoiced much because of the Christian faith but even more because of the firm, manly, and wise words which...Smbat spoke before him.".137

The Armenians needed to see that their military allies supported the Christian faith. Grigor of Akner praised Hülegü numerous times in his support of Christianity. Grigor and Vardan both related: "Hulawu Khan was very good, loving Christians, the church, and priests. Likewise his blessed wife Tawvus Xatun, who was good in every way, and was compassionate to the poor and needy. She very much loved all Christians, Armenians and Syrians, so that her tent was a church, and a sounder traveled with her, and many Armenian and Syrian priests." ${ }^{" 138}$ Grigor went further in his description: "Hulawu Гan [Hülegü Khan] himself was a great mind and great soul, just, and quite learned. He was a great shedder of blood, but he slew only the wicked and his enemies, and not the good or righteous. He loved the Christian folk more than the infidels." 39

${ }^{136}$ Grigor, Nation of Archers, 313-15.

${ }^{137}$ Ibid. 315.

${ }^{138}$ Ibid. 341.

${ }^{139}$ Ibid. 343. 
Grigor of Akner described a gathering between Hetum I and his princes, priests, and nobles in which Hetum praised the service of his son Toros, who was killed in battle against the Mamluks. Hetum also mentioned the service of horsemen, which most likely referred to the Mongols: "Just as such a number of horsemen strove on behalf of the Christians, and became worthy of heavenly crowns, so also did my sons. Toros strove valiantly for the Christians and contended for the Christians." 140

Hetum I, king of Cilician Armenia, demanded that the Mongols restore the Holy Land to Christian hands. According to Hetum Patmich, Hetum I expressed his desire both to Möngke Khan at Karakorum in $1253 / 54$ and then to Hülegü at Maragheh in $1258 .{ }^{141}$ Hetum I and his successors also made appeals to the Christian West to help liberate the Holy Land. The Armenians hoped that the Western powers "would join forces with [Armenia's] powerful and some time Christian Tatar [Mongol] overlords and assist in their delivery of the 'Holy Land' to their righteous [Armenian] safe keeping. They alone among these thirteenth-century would-be allies appeared to whole-heartedly endorse the concept of an all out united war to rid Syria and Egypt of the infidel Muslims."142

The Armenians sought to improve the standing of their Christian Church by appealing to the Ilkhans, asking for the churches to be exempt from Mongol taxes. According to Grigor of Akner, the Cilician Armenians received such benefits. After the return of Smbat from Karakorum, the Mongols ordered Hetum to go and see Möngke Khan: "The pious King Hetum, seeing his brother Baron Smbat thus favored with such an honor, and esteemed by the Khan, rejoiced greatly. He rejoiced even more because of the

\footnotetext{
${ }^{140}$ Grigor, Nation of Archers, 363.

${ }_{141}$ Dashdondog, the Armenians, 133.

${ }^{142}$ Lane, Persian Renaissance, 56.
} 
documents regarding the freeing from taxes of our land and our monasteries, and of all Christians." $" 143$

According to the Armenian chronicler Kirakos, King Hetum I drafted a list of appeals, which he presented to the Great Khan, upon offering his submission. In this list Hetum I asked for the Great Khan to convert to Christianity and be baptized, as well as allow the establishment of Christian churches in all Mongol lands and that the Armenians be freed from all taxes. He also demanded that Möngke Khan free the Holy Land from the Mamluks and give the Christians jurisdiction there. Other requests of a less religious nature included that the Mongols suppress the Caliph of Baghdad, that the Mongols offer the Armenians help in times of need, and that all lands of the Armenians taken by the Mamluks be given back to the Armenians. ${ }^{144}$

Hetum also asked for the Armenian Church to receive exemptions from taxes. According to Grigor, Hetum was successful in his petitioning and described his trip in this manner:

The pious King of the Armenians, Hetum, heard that Hulawu Гan [Hülegü Khan] had been enthroned, and that he was so friendly and pro-Christian; then the Armenian King himself also went to the east with many gifts. He saw Hulawu $\Gamma$ an, and when the Khan saw the King of Armenia he liked him very much and honored him. He wrote a second charter (lit., freedom) for his kingdom, but more especially for the churches and ecclesiastics, and for all the Christians of the country. With such honor and great wealth he dispatched the King of the Armenians to his country. ${ }^{145}$

In Greater Armenia, some areas were more successful in gaining exemptions from taxes. The historic records show that these exemptions were given to selective churches and princes and the exemptions themselves were not uniform. In 1287, the Ilkhan Arghun

\footnotetext{
${ }^{143}$ Grigor, Nation of Archers, 315.

${ }_{144}$ Dashdondog, the Armenians, 87.

${ }^{145}$ Grigor, Nation of Archers, 341-43.
} 
(r. 1284-1291) made a decree that eliminated 150 Armenian monasteries and convents from the royal tax registry. This decree was in actuality a confirmation of an earlier decree in which Tarsaich Orbelian succeeded in securing these tax exemptions. ${ }^{146}$

In his list of petitions, Hetum also asked the Ilkhan to spare the Christian communities in all of the conquered cities. When Baghdad was captured, the Christians who lived there were spared by the invading Mongols, apparently by the goodwill and intervention of Hülegü's Christian wife, Toluz Khatun. According to Vardan: "Hulawu [Hülegü] went to the land of Mesopotamia and captured those cities and provinces...the patriarch of Armenia, the Catholicos, came to him, blessed him and was befriended by him. When he took all the country of Săm [Syria], there was also with him our crowned [King] Hetum who freed from death the Christians, ecclesiastics and laymen, in every place..."147 It was clear in both the Armenian and Arabic sources that the Mongols attempted such a policy, but it was not uniformly enforced and it experienced mixed success.

\section{Harmful Effects of Mongol Allegiance}

Unfortunately for the Armenians, there were numerous risks in their Ilkhanid alliance, many of which did not transform into benefits. These losses naturally reflected negatively on the Armenian-Ilkhanid alliance and served as a means in determining whether the Ilkhanid alliance was ultimately beneficial or not for the Armenians, both in Cilicia and Greater Armenia. For the Kingdom of Cilician Armenia, the most significant negative impact that resulted from their Ilkhanid alliance was that the alliance brought them into direct contact with the Egyptian Mamluks, who quickly became a fierce

\footnotetext{
${ }^{146}$ Dashdondog, the Armenians, 181.

${ }^{147}$ Vardan, Compilation, 217-18.
} 
enemy. In fact, it would be the Mamluks who would ultimately destroy the Kingdom of Cilician Armenia in 1375 (the Ilkhanate had already collapsed in 1335). The Mamluks attacked the Armenians during lags in their conflicts with the Ilkhanid Mongols and Crusaders; they often attacked in retribution for the Armenian raids into northern Syria, land the Mamluks considered theirs.

The military threat of the Mamluks would not have been a problem if the Cilician Armenians had the consistent and strong military support of their Ilkhanid ally. Unfortunately this was not the case. The Ilkhanid Mongols were usually so engrossed with wars against the other branches of the Chinggisid family that they could not come to the aid of the Armenians. The Armenians and Georgians were in dire need of military assistance and protection against the Mongol rebel Teguder, who had challenged the ascension of Abaqa to the throne of the Ilkhanate and was ravaging the Armenian countryside and "the exactions of this lawless chieftain [Teguder] weighed upon the eastern monasteries. Learning of this the Armenian and Georgian princes went together to Abaya Tan [Abaqa Khan] and cast their swords before the Khan and said 'Either give Tagudar [Teguder] and his troops into our hands, or kill us in front of you, so as not to see such outrages as they are doing to our churches and to the clergy.",148

Not only was it impossible for the Mongols to send aid to the Armenians against their enemies, it seemed impossible for the Mongols to defeat Teguder without the Armenians' aid (or at least this is how Grigor painted the picture). The Armenians and Georgians were continually pulled into these civil wars and forced to fight for the Ilkhan:

He [Abaqa] gave the [Great] Khan's own seal into the hands of Siramun [Mongol commander]. Likewise he ordered the Armenian and Georgian

\footnotetext{
${ }^{148}$ Grigor, Nation of Archers, 375-77.
} 
forces to go themselves in full strength against Tagudar [Teguder], and mercilessly to slay his forces...take all of his things, and to bring Tagudar himself alive before him [Abaqa]. Hearing this the Armenian and Georgian troops were very happy at the freeing of their land from the evil deeds of Tagudar. They bravely mustered themselves for war, likewise Siramun, the son of Cawrmayan [Chormaghan], who was very well disposed towards the Christians. Taking the Khan's standard and one hundred thousand troops, he suddenly fell on Tagudar and mercilessly slaughtered his troops. They took all of his treasure, and himself with seven hundred men whom they brought to the Khan. ${ }^{149}$

This particular piece of evidence also showed that the Mongols were able to eventually give their military protection to the Armenians against the Mongol rebel Teguder. Despite this example, overall it seemed that the Armenians came to the aid of the Mongols much more than the Mongols aided them.

The greatest example of this lack of support and its dire consequences came when King Hetum I conducted raids into northern Syria, taking booty from the areas around Aleppo in 1262. He conducted several more raids from 1262-64, but all were unsuccessful. ${ }^{150} \mathrm{He}$ assumed he would receive Mongol support and protection and therefore need not worry about Mamluk retribution. But when the Mamluks came to address this grievance, the Mongols were not there to protect Hetum I and his kingdom suffered greatly for it. As the thirteenth century progressed, the Mamluks grew stronger and "in the last decade of the thirteenth century, their attacks intensified. In 1291, with the fall of Acre and Tyre, the Crusaders' power in Syria-Palestine was destroyed forever, leaving Armenia, under King Hethum II, as the last Christian bastion on the Asiatic mainland, supporting and supported by Cyprus."151

\footnotetext{
${ }^{149}$ Ibid. 377.

${ }^{150}$ Hetum I was not very successful in his efforts. After acquiring some booty from Aleppo he was chased out by a small Muslim force. He also made multiple attempts to take the fort of Aintab, but failed, see Dashdondog, the Armenians, 148-49.

${ }^{151}$ Chahin, The Kingdom of Armenia, 289.
} 
Grigor stated that Hetum I refused to cooperate with the Mamluks because he

believed he had the support of his nobles. He never mentioned the Mongols or the

expectation of their support:

Then the infidel and ferocious Sultan of Egypt came with a great force to Damascus, and from there sent ambassadors to the King of the Armenians in regard to some trifle which he wanted from the King. The Armenian King did not give it; rather he answered insulting words calling him a $<$ dog $>$ and a slave... He did not make peace, but remained hostile to him and insubordinate, knowing that his father the Baron was alive and his princes united. ${ }^{152}$

It must be noted that Grigor seemed to contradict himself here in his description of the Armenians' loyalties to Hetum I's policies. In the above quote, he stated that the princes were united with Hetum and that he could expect their military support. But then later in his work, Grigor blamed the Armenian defeat at the hands of the Mamluks on the Armenian army's rebelliousness, which led to the Prince Toros's death and the capture of Prince Lewon.

Which story to believe was less important than what the quotation below can convey about Mongol-Armenian relations:

Then the Armenian King, when he learned of the invasion of the Turks [Mamluks] into his country, mustered his forces and entrusted them to his sons, the crown princes, Lewon and Toros. He himself with his small detachment went to the Tatars [Mongols] who were sojourning between Ablstin and Kokeson. He remained there several days, not knowing of the dissensions in his army. Once he persuaded the chieftain of the Tatars to come and aid his troops, he came back two days ahead of them. Then he heard of the coming of the Turks and the defeat of his rebellious army, how they betrayed his sons, the crown princes, into the hands of the infidel wolves, and they themselves fled to their strongholds; that they (the Turks) [Mamluks] had struck down his handsomest son the prince, Baron Toros, from his horse in the battle. The Turks [Mamluks] had seized Baron Lewon and many of his troops, taking them prisoners to Egypt. ${ }^{153}$

${ }^{152}$ Grigor, Nation of Archers, 355-57.

${ }^{153}$ Grigor, Nation of Archers, 357. 
In the description above, the Mongols were persuaded to come to the aid of the Armenians, but arrived too late. This attempt at least showed that the Mongols did offer military aid to the Armenians, but to what extent and to what result cannot be known from this evidence.

The Armenians' political reliance on the Mongols went against Armenian interests in the vast majority of cases. One such example of the political reliance of the Armenians on the Mongols was when Lewon, son of Hetum I, uncovered and dealt with a rebellion against his accession to the Armenian throne. Grigor explained that the Mongols allowed Lewon to imprison some of the rebels and kill others, while still "others [Lewon] dispatched to Abaya Tan [Abaqa Khan] in the east. There they imposed the yasax [yasa] on them, and all other enemies they (the Mongols) gave into his hands, and they ordered him either to imprison them or to kill them." ${ }^{54}$ Clearly political subservience to the Mongols required that the Mongol law code, the yasa, took precedence over any Armenian law code.

Another negative result of the Armenians' political links with the Mongols was that the Mamluks often attacked the Mongols indirectly by attacking the Armenians. Obviously, this tactic would have only hurt the Armenians. One such example was when the Ilkhan Arghun sought to steal the Egyptians' profitable trade routes in the Red Sea by constructing a naval fleet in Baghdad for this expressed purpose. In revenge, the Sultan Qalawun raided and pillaged the Cilician Armenians in $1285 .{ }^{155}$

The Ilkhanate's internal politics regularly went against Armenian interests. But it was also the case that the Armenians' enemies attempted to use the Mongol political

\footnotetext{
${ }^{154}$ Grigor, Nation of Archers, 381.

${ }^{155}$ Dashdondog, the Armenians, 181.
} 
system to attack the Armenians. There were multiple attempts to sow distrust in the Ilkhan's court against the Armenians. These dissenters had a strong grasp of the Mongols' laws and sought to use the Mongols' harsh rules against the Armenians. According to Grigor of Akner, some Armenian princes resided at the court of Abaqa Khan and fed information back to King Hetum I on the court's politics. These princes secretly sent back word that:

Arab amirs had become advisers and associates of the Khan. In secret they were friendly to the Egyptians and evilly disposed to the king of the Armenians and to all Christians. The Arab amirs had become favorites and <advisers> of the Khan, and had written to the Sultan of Egypt in secret: 'Seek by goodwill to obtain one village from the Armenian King, and this will be sufficient and more than enough to ruin him and his country. We will tell and advise the Khan that the Armenian King is damaging the whole world, and he will send horsemen to slay them all.,156

The Mongols had conquered most of the lands the Armenian king now administered and as such, the Armenian king was not allowed to give away land that was not his. If he did so, his action would be viewed as an act of betrayal against the Mongols and he would be labeled as a traitor. The Mongols would then kill this traitor. The Arab amirs understood the Mongols' strict policies and sought to use them to their benefit. If they could frame the Armenian king as a traitor, then they could sit back and let Mongolian justice take its course. This incident shows the destructive potential of the Mongols' political and legal system on their vassals.

Still another negative impact on the Armenian political system was that the alliance with the Mongols took away the Armenians' abilities to negotiate treaties. As part of the treaty of 1285, the Mamluk Sultan Baybars demanded the surrender of key fortresses in Cilician Armenia's possession. Hetum I did not want to give up these

\footnotetext{
${ }^{156}$ Grigor, Nation of Archers, 367.
} 
frontier holdings because he feared the anger of the Mongols, who would blame him for having fallen under the influence of the Sultan if he gave them the fortresses the Mongols had captured. ${ }^{157}$ Vardan Arewelci described how the Armenians' conflict with the Mamluks came about:

...The Sultan of Egypt called Pntxtar [Baybars] demanded the castles which Hetum, the king of Armenia, had taken with the Tatars' [Mongols'] support. When he did not give them up, notably because of his fear of the Tatars, he was greatly enraged. Gathering a vast army... sent it against Cilicia... [the Mamluks] captured the capital city Sis, the royal residence, burned it and the churches there...Among the killed the foremost mortally wounded was the king's son Toros, in the flower of his youth... [the] elder brother [Lewon] ... had been crowned and raised to the royal throne during his father's [Hetum's] lifetime. [Lewon] was foremost of the captives... ${ }^{158}$

The Mamluks dealt massive blows to the Cilician Armenians, not only materially but also in the disruption and destruction of the Armenian leadership. King Hetum I lost his second son and heir, but more significant was the capture of his first son and primary heir. His first son, Lewon, had assumed joint rule with his father Hetum by this point; thus the Armenians truly lost one of their kings. Also, the financial and political burden the Cilician Armenians experienced to successfully ransom Lewon surely undercut significantly the kingdom's ability to recover from the Mamluks' devastation.

Multiple Mamluk campaigns into Cilicia crushed Armenian resistance, forcing the Armenians to accept an embarrassing and extremely disadvantageous treaty in 1285 . The treaty was negotiated separately from the Armenians' Mongol overlords and forced the Armenians to become vassals of the Mamluks. King Hetum I had to relinquish a number of key fortresses, while his son, Lewon, was forced to sign the peace treaty during his captivity in Egypt. The Arabic author Abd al-Zathir explained the terms of the ten-year

\footnotetext{
${ }^{157}$ The Sultan also wanted to acquire less ruined frontier holdings for his trade routes and market places, see Dashdondog, the Armenians, 161.

${ }^{158}$ Vardan, Compilation, 223.
} 
treaty: the Cilician Armenians had to pay an annual tribute of one million dirhams. The Armenians had to also give annually twenty-five pedigree horses, the same number in mules, and 10,000 iron bars for horseshoes and nails. ${ }^{159}$

After the ten-year treaty, the Mamluks, under the leadership of the Sultan AlNasir Muhammad b. Qalawun (r. 1293-94, 1299-1309, 1310-1340), continued to exert economic pressure on Cilician Armenia and forced them to accept tributary status. ${ }^{160}$ The Mamluks took advantage of the weak Armenian King Hetum II (r. 1295-96, 1299-1303, 1303-1307) by conducting constant raids into Cilicia. Hetum II sought to appease the Egyptians with large sums of money, but this tactic failed, as did every attempt by the Armenians to repel Mamluk attacks. In 1292, the Sultan al-Ashraf Khalil b. Qalawun (r. 1290-93) seized Hromklay, which was the See of the Armenian Catholicos, situated on the Euphrates River. Hetum II had to provide a large sum of money and hand over the great fortress of Behest to secure the Catholicos's freedom from Egyptian captivity. ${ }^{161}$

After the fall of Hromklay in 1292, the Ilkhan Geikhatu (r. 1291-95) came forward and threatened the Mamluk Sultan al-Ashraf, stating that since the Sultan sacked Hromklay, the Mongols would retaliate by attacking Aleppo. Al-Ashraf countered by threatening to sack Baghdad. From an analysis of Rashid al-Din, it was not clear whether the llkhan issued this threat from some sense of loyalty to the Armenians. What was clear was that Al-Ashraf's threat kept Geikhatu in Baghdad. In essence the Ilkhan chose to protect Baghdad instead of coming to the aid of the Cilician Armenians. ${ }^{162}$ It was to be

\footnotetext{
${ }^{159}$ Dashdondog, the Armenians, 181-82.

${ }^{160}$ Ibid. 182-184.

${ }^{161}$ Ibid. 186.

162 Ibid. 187.
} 
expected that the Ilkhans would put the Ilkhanate's interests and protection before that of the Armenians and that this example was only one of what actually occurred.

A curious event during the siege of Hromklay may show an example of the Mongol failure to offer military aid to the Armenians. During the siege King Hetum II attempted to relieve the city by a cunning tactic: the Armenians posed as Mongols by wearing Mongol caps (saraqujat) and attacking the Mamluk caravans and supply trains. This tactic proved unsuccessful once Sultan al-Ashraf uncovered the ruse and attacked the citadel, securing the city for the Mamluks. ${ }^{163}$ The primary sources, Abul-Fida and the Armenian fourteenth century chronicler Nerses Palients, never explained why the Armenians adopted this tactic. It was highly probable that the Armenians wished to capitalize on the Mongols' threatening and fierce presence, thus forcing their enemy to fight with more caution or hesitation. If this were true then why would the Armenians need to dress as Mongols unless they had no Mongols with them? To achieve their military tactic of Mongol intimidation, the Armenians would have to do it themselves. The adoption of this tactic may also show that the Armenians greatly needed the assistance of the Mongols, but did not receive it. Thus, this was another example of the Mongols failing to offer military protection to the Armenians.

Mongol policy in Greater Armenia was not much different; they often failed to offer military protection to the princes of Greater Armenia and they forbade the princes from negotiating with other powers. It was crucial for the Mongols to aggressively enforce the latter policy because another Chinggisid branch, the Golden Horde, interacted with Greater Armenia and the Ilkhanate needed to ensure the Armenian princes' loyalty. This Ilkhanid policy was detrimental to Greater Armenia because it ensured that there

${ }^{163}$ Ibid. 186. 
was always a strong enemy on the Armenians' doorstep, since the Golden Horde laid claim to the territories of the northern Caucasus. This fact, coupled with the Ilkhanate's inability to offer military protection, created a terrible situation for the Armenians. Armenia and Georgia became the primary battlegrounds between the Ilkhanate and the Golden Horde almost every year of the conflict in the second half of the thirteenth century. According to their subject status, the Greater Armenians had to side with the Ilkhans, which included providing provisions and troops. ${ }^{164}$ It was entirely possible that an alliance with the Golden Horde could have offered more benefits to the Armenians than their present alliance with the Ilkhanate, but their alliance prevented them from opening negotiations with the Golden Horde. It also prevented them from negotiating peace treaties or any avenue that could stem the flow of supplies and men out of the country or end the devastation of the land.

A great number of Armenians fought in the Mongol civil wars, as mentioned by Grigor: "Again the messengers of Manku Гan [Möngke Khan] ordered the Armenian and Georgian forces, as well as the forces of Hulawu [Hülegü], to go and attack their armies and to slay them mercilessly. So they did. They killed so many that the mountains and plains stank from the bodies of the slain Tatars." 165 These rebel Mongols were those sons of Möngke Khan who refused to accept Hülegü's appointment as Khan in the west. The four rebellious sons were killed and their armies defeated.

In addition to preventing autonomous treaty negotiations, the Ilkhanid alliance brought the Armenians into political situations and negotiations that were often not advantageous for the Armenians. This was especially the case with the Egyptian

\footnotetext{
${ }^{164}$ Ibid. 150.

${ }^{165}$ Grigor, Nation of Archers, 341.
} 
Mamluks. It is surprising how intimately linked these three powers could be with one another. Grigor provided an explanation of a political arrangement made among the three kingdoms that seemed to offer a mixed bag for the Armenians:

The King of the Armenians [Hetum I]....sent an ambassador to the Sultan of Egypt to learn about his son Lewon, and what the wish of the Sultan might be, what he might give and ransom his son. The Sultan of Egypt, Pnduxtar [Baybars]... when he heard of the arrival of the ambassadors he rejoiced and said, 'We should send Lewon to his father and to his kingdom. I have a beloved comrade a prisoner with the Tatars [Mongols]. Obtain him by your own efforts. If you want to get him from the Tatars they will not cause trouble. Take him, Syur [Sunqur al-Ashqar] ${ }^{166}$ by name, and take Lewon away. 167

When considering this specific example, it had both beneficial and detrimental aspects

for the Armenians. The Armenians' connection with the Mongols allowed them to broker the deal to secure Sunqur al-Ashqar for the Mamluks. In this case, the Armenians had something to offer the Mamluks in exchange for Lewon:

The Armenian king at once gathering many treasures and precious things, went to the east to Abaya Гan [Abaqa Khan]. He told him all of his complaints, what the Egyptians had done to him and his country. He also told of the request of the Sultan regarding the captive Syur [Sunqur], but he was unable to obtain him at once. He came back and sent his nephew, who with the aid of God went and brought Syur the captive to our country....When the [Armenian] King sent to the Sultan saying, 'Syur has been brought,' the Sultan was very happy and at once dispatched Lewon with many presents. They (the Armenians) sent Syur with many presents. When Baron Lewon came, the King was very happy, and the princes of the country, as well as the monks and all Christians who were in the entire land. ${ }^{168}$

If the Armenians had not been connected to the Mongols, they would have had much less to offer the Mamluks and hence, fewer possibilities for peace. On the other hand, it was clearly detrimental to the Armenians that they could not negotiate their own treaties and

\footnotetext{
${ }^{166}$ Sunqur al-Ashqar was called the 'hunting falcon' and was captured by the Mongols when they took Aleppo in 1280, see Grigor, Nation of Archers, 390.

${ }^{167}$ Grigor, Nation of Archers, 369.

${ }^{168}$ Ibid. 371.
} 
truly be able to put their interests first. The Armenians were also at a disadvantage when confronted by the Mamluks, because the Mamluks could and did act independently, but the Armenians were constrained by the Mongols. They had to allow the Mongols into their negotiations or they would be punished. They also had to rely on the Mongols militarily, because they could not successfully prosecute any campaigns. This can be seen from Hetum I's failed incursions into northern Syria.

Another negative aspect of the Mongol alliance for the Armenians was the very real threat of the Mongols themselves. If the Mongols perceived that a vassal had betrayed them they would seek retribution. There were several examples in which the Armenians were punished for transgressions, real or imagined. Early in their relationship with Möngke Khan, the Armenian and Georgian princes were accused of speaking boastful words against the Mongols saying they would beat them in battle. This was taken as a threat and act of treachery: "Then they (the Tatars) believed the false words and invaded our [Armenian and Georgian] country, taking as plunder all of the possessions and flocks of the people. But they did not kill the population, being without any order from the great Khan. They seized the King and all of the princes of the nation [and brought them to the court of the Mongol chieftain to be tried]." ${ }^{169}$ Fortunately, the Armenian Prince Awag was able to convince the Mongols of their innocence and the Mongols stopped their destruction of the land.

Another incident of Armenian/Georgian treachery did not end so positively. Vardan related the following episode: "[The Mongols] murdered at the court of [Hülegü] the Georgian general Zakare...in the flower of his youth...Indeed, they falsely accused

${ }^{169}$ Ibid. 323. 
him of holding back the due tax at the time when he himself went to the court." ${ }^{, 170}$ Not even high-ranking nobles were safe from Mongol punishment. In fact, these leaders were the ones who bore the brunt of Mongol punishment and pressure. This struggle to walk a thin line was certainly a negative consequence and stressor in the Armenians' relationship with the Mongols.

Both Greater Armenia and Cilician Armenia experienced heavy material burdens as a result of their alliances with the Mongols. Kirakos of Ganjak mentioned several different taxes imposed on the princes and territories of Greater Armenia. Kirakos had this to say on the taxation practices: "[the Mongols] began to harass them [the Armenian princes] through taxation, by traveling to and fro, and by soldiership and even more than this, they placed them under duress, but killed no one." ${ }^{.171}$ One such financial burden was a tax levied against provincial peoples for the maintenance of the yam system. The yam was a well-maintained way station system that supported messenger riders, who transported messages across the Mongol Empire. Kirakos further reported that artisans, anglers, miners, and manufacturers were heavily taxed. The increased Mongol taxation in 1245-46 drove some Armenian nobles from their lands and forced them to flee to their fortresses. Other Mongol taxes made some Caucasian nobles mortgage their estates to pay this tax. ${ }^{172}$ Currently, historians have not found any comparative taxation data for Cilician Armenia.

Some Armenians had already experienced heavy taxation at the hands of the Mongols. Grigor of Akner recounted taxes levied in 1251-52 in the 'upper districts of the

\footnotetext{
${ }^{170}$ Vardan, Compilation, 218.

${ }^{171}$ Kirakos, the Armenians, quoted in Dashdondog, the Armenians, 115.

${ }^{172}$ Dashdondog, the Armenians, 119.
} 
east.' This phrase was likely referencing Greater Armenia, being east of Cilician Armenia:

A Tatar chieftain, Ardun by name, came by the command of Manku Гan [Möngke Khan] and took a census of the eastern country for the taxes. From this time on they were wont to tax according to the number of heads of the people, as many were inscribed on the books, but still more they plundered the country of the east. In one small village they counted from thirty to fifty men all from fifteen to sixty years of age. They took sixty aspers from each person who was counted. ${ }^{173}$

These same tax rates (or very similar) were most likely in place when Hülegü took power in 1260 .

The Mongols relied heavily on Greater Armenia to provide large supply trains for the Mongol army. The Armenians provided most of the provisions for the Mongol armies during their war with the Ismailis in $1256 .{ }^{174}$ According to Dashdondog, if all of the food levies were enforced, Greater Armenia would have surely faced economic crisis and famine in $1256 .{ }^{175}$ Rashid al-Din also stated that the Armenians were the main foodstuffs provider to the Mongol armies. The Mongols decided to transport supplies from Armenia to Yazd and every community in these lands had to pay food levies, the ulagh and taghar, even when Greater Armenia faced famine in $1256 .{ }^{176}$ The taghar was to "be collected from each individual listed in the royal register. From such they demanded one hundred litrs [pounds] of grain, fifty litrs of wine, two litrs of rice and husks, three sacks, two cords, one spitak [silver coin], one arrow, let alone the other bribes; and one in every twenty animals plus twenty spitaks."177 This was a great sum to be paid and it was

\footnotetext{
${ }^{173}$ Grigor, Nation of Archers, 325.

${ }^{174}$ Dashdondog, the Armenians, 113.

${ }^{175}$ Ibid. 113-114.

${ }^{176}$ Ibid. 126.

${ }^{177}$ Kirakos, the Armenians, quoted in Dashdondog, the Armenians, 113.
} 
unclear whether this tax was enacted on an annual or other temporal basis, or on the command of the Ilkhan.

Greater Armenia and Cilician Armenia both experienced great material destruction of their lands and cities as a result of their alliances with the Mongols. Greater Armenia was the battleground between the Ilkhanate and the Golden Horde; therefore their lands were often ruined and their lands had not yet recovered from the two previous Mongol invasions. Cilician Armenia experienced widespread destruction from the numerous Mamluk raids and expeditions. All of Cilician Armenia's cities were devastated at least once, especially the capital of Sis.

Perhaps greater than the destruction of land was the loss of human lives. The primary sources included numerous references to the high mortality experienced by the Armenian military and its nobility. The Caucasian forces made up a large percentage of the Ilkhanid army through most of the Armenian-Ilkhanid alliance. This would have been a large drain on Caucasian society. One such example was that more than one third of the Mongol army commanded by Mengu Temur in 1281, was made up of Armenians, Georgians and other auxiliary cavalry. ${ }^{178}$ There was immense pressure on the Armenian princes to consistently provide large numbers of troops to the Mongols. Hülegü pushed for Armenian and Georgian lords to participate in his further conquests or in his wars against his Mongol relatives, in particular between 1260-65. The Armenians and Georgians experienced high casualties from both, much more so during the inter-familial wars. ${ }^{179}$ Kirakos of Ganjak attributed the Caucasian lords' rebellion (1259-61) in large part to the Mongols' great demands for troops. The Georgian King David I (r. 1258-

\footnotetext{
${ }^{178}$ Amitai-Preiss, Mamluk-Ilkhanid War, 227.

${ }^{179}$ Dashdondog, the Armenians, 156.
} 
1293) refused Hülegü's order to support his conquest of Syria and Egypt by providing troops. David and the Georgians were exhausted from battling for Baghdad and this was the reasoning given for his refusal to follow Hülegü's orders. ${ }^{180}$

In addition to the losses incurred by the regular soldiery, the Armenian nobles experienced significant mortality because of their role as martial leaders. Stepannos Orbelian related how the young prince Burtel Orbelian was killed in the northern Caucasus in 1261-62 while serving Hülegü against Berke Khan, khan of the Golden Horde (d. 1266). ${ }^{181}$ Vardan Arewelci related another casualty during the siege of the City of Martyrs in 1260 during Hülegü's initial conquest in the Middle East: "The City of Martyrs was taken after much misery and damage, not only for the besieged but also for the besieging Tatar soldiers and the Christians with them. They battled each other within and without; and there the handsome youth Sewada Xačeneci, son of the great prince Grigor, was killed fighting valiantly. He was crowned with those who keep the faith and fear of God and of the Il-khan...,"182

There were several competing theories on why the Mongols would utilize the Armenian armies to such a great extent. According to Reuven Amitai-Preiss:

Because the Mongols considered their subject people expendable, they usually designated them as advance attackers. This was not, as the History of Kartli and Grigor of Akner would have us believe, because the Armeno-Georgian troops were such excellent warriors, but first precisely because the Caucasians were expendable and second, because desertion was impossible with foreign troops fighting in front or in detachments surrounded by Mongols. ${ }^{183}$

\footnotetext{
${ }^{180}$ Ibid. 153.

181 Ibid. 153.

${ }^{182}$ Vardan, Compilation, 218.

${ }^{183}$ Amitai-Preiss, Mamluk-Ilkhanid War, 225.
} 
If this were the case, certainly the Armenians would not have benefited from this advance attackers tactic and it certainly called into question the overall worth of the Armenian-Ilkhanid alliance.

Finally, the Armenians experienced territorial losses as a result of their alliance with the Ilkhanid Mongols. Cilician Armenia quickly lost all of the lands it had gained through its raids into northern Syria. The Cilician Armenians' war with the Mamluks eventually destroyed the entire Kingdom of Cilician Armenia in 1375. If it had not been for their alliance with the Mongols, the Cilician Armenians may not have come into direct contact with the Mamluks or instigated Mamluk retaliation. But as this was the case, the Mamluks crushed them.

In summarizing the above evidence, it was clear that the Armenians experienced many more negative consequences from their alliance with the Ilkhanid Mongols than positive consequences. On first consideration this notion may seem surprising as the prevailing viewpoint of the time was that the Mongols were the most powerful and successful force in the region and it was presumed that they would continue in this role. External enemies, such as the Egyptian Mamluks and the Golden Horde, played a part in keeping the Mongols from fulfilling their lordly obligations to the Armenians, but it was the demands of the Mongols themselves on their Armenian vassals that ultimately showed how the Mongol-Armenian alliance was predominantly negative for the Armenians.

Both Greater Armenia and the kingdom of Cilician Armenia submitted to the Mongols, although under different circumstances. The princes of Greater Armenia surrendered after a hard fought resistance, while Cilician Armenia voluntarily 
surrendered before the Mongols could devastate the kingdom. Mongol terms of submission required the Armenian leaders to provide troops and provisions to the Mongol army; accept Mongol overlordship; act as a loyal vassal; and pay taxes. In exchange, the Mongols often returned the land to the nobility and showed political favoritism; offered pardons and military protection; instilled religious tolerance; preserved internal administration; instituted selective tax exemptions; and offered noble marriages into the Chinggisid line. Of these benefits, the Armenians received almost all of them on a selective basis. The most important benefit, military protection, was sorely lacking. The Armenians received few of the benefits they actively sought, such as tax exemptions for churches; the liberation of the Holy Land; the safeguarding of Christianity in Mongol conquered cities and the spread of Christianity through the Mongol Empire; the acquisition of land in northern Syria; and the attainment of wealth and political power in their surrounding regions. The most significant aspect that shaped Mongol-Armenian relations into a chiefly negative venture for the Armenians was the weight and severity of Mongol demands. The constant demand for supplies and troops drained both Greater Armenia and Cilician Armenia, leaving their peoples vulnerable to enemy attacks and famine. As a result of showing their loyalty to the Mongol alliance, Cilician Armenia was consistently attacked and devastated by the Mamluks, while Greater Armenia suffered from the raids of the Golden Horde. The Armenians were never able to negotiate their own peace treaties, which left them in a constant state of war with an absent military ally. 


\section{THE MONGOLS AND THE EGYPTIAN MAMLUKS}

This section will examine primary evidence in English translation relating to the interactions between the Ilkhanid Mongols and the Egyptian Mamluks. This section will ultimately argue that based on the analysis of primary and secondary literature, the Mamluks gained more beneficial outcomes from their adversarial relationship with the Ilkhanid Mongols and these benefits greatly overshadowed the negatives. Ultimately waging war on the Mongols proved highly beneficial in the long term for the Mamluks. This runs contrary to the expectation that being an enemy of the Mongols would prove to be highly destructive for any of their enemies.

This section will begin with a summary of the Mamluk overthrow of the Egyptian Ayyubid Sultanate and their initial interactions with the Ilkhanid Mongols. Next, there will be an analysis of the benefits the Mamluks earned from being an enemy of the Ilkhanate, both those they actively pursued and those earned unexpectedly. The chief benefit was that the threat of the Mongols provided the clear impetus to have a martial ruling system in Egypt and that waging warfare extended the ruling legitimacy for the Mamluks. It also allowed them to show themselves as the protector and patron of Islam and they had a clear target in these Mongol outsiders to wage jihad against. Finally, the Mongol conquest of Baghdad initiated the re-location of the Caliphate in Cairo.

The focus will then shift to analyzing the negative effects the Mamluks experienced from their war with the Ilkhanate. These negative effects are divided into 
subtopics: the impact of the Ilkhanid conversion to Islam; the loss of ruling legitimacy when compared to the noble Chinggisid bloodline; Mongol threats to Mamluk commercial interests; as well as material losses.

From the beginning of their interactions with the Ilkhanid Mongols, the Mamluks took an adversarial stance. On the eve of Hülegü's march west, the Mamluks were locked in an intense civil war. The Mamluks had successfully seized the Egyptian throne in 1250 from the Ayyubid dynasty, but the Mamluks quickly began fighting among themselves. The newly installed Sultan Aybeg feared the Bahriyya's power and murdered their leader Faris al-Din Aqtay. Most of the Bahriyya, some 700 mamluks, with their leader Baybars fled to Syria in 1254. Baybars and his men spent the next several years serving al-Nasir Yusuf, ruler of Aleppo and Damascus, and al-Mughith Umar, ruler of Karak. ${ }^{184}$

During this chaotic time, Sultan Aybeg died, leaving the throne to his young son. Aybeg's favored mamluk, Qutuz, installed the son of Aybeg on the throne as a puppet and Qutuz ruled through him for a time. Qutuz then deposed the boy and took direct control in 1259. Qutuz rose to power and justified taking the throne because of the Mongols' advance west. Upon Qutuz's rise, he and Baybars reconciled and Baybars returned to Egypt. ${ }^{185}$

Despite deposing the Ayyubids in Egypt, the Ayyubid princes remained strong and influential in others areas of the Middle East, Syria in particular. Upon the eve of the expected Mongol invasion, the Mamluks attempted to gain Ayyubid allies in Syria, both to garner military support and consolidate their own position to avoid war on multiple fronts. As with the Ilkhanid Mongols, the Mamluks had mixed results in securing strong

\footnotetext{
${ }^{184}$ Amitai-Preiss, Mamluk-Ilkhanid War, 19.

${ }^{185}$ Qutuz was the actual killer of Aqtay, former leader of the Bahriyya and Baybars's leader.
} 
alliances with the Ayyubids. They too had to deal with the duplicity of al-Nasir Yusuf $b$. al-Aziz Muhammad, ruler of Aleppo and Damascus. One of the main factors for Baybars's return to Egypt was because Yusuf could not take a decisive stance toward the Mongols. But the Mamluks did gain a stable ally in al-Mansur Muhammad b. alMuzaffar Mahmud, ruler of Hama. For his faithfulness he was rewarded by regaining his kingdom and acquiring the lands of Maarrat al-Numan and Barin. ${ }^{186}$

The Mamluks were military elites of the Eurasian steppe who converted to Islam and functioned as the urban military class in Egypt. ${ }^{187}$ They ruled over large Muslim populations and based their armies on disciplined masses of mounted archers, which was a testament to their Kipchak origin. ${ }^{188}$ The early Mamluk sultans like Qutuz and Baybars, created a larger and stronger army through more intense training; firmly managed and utilized the Bedouins; ${ }^{189}$ erected fortifications; established an effective espionage system; organized the military administration; established rapid communications throughout the country; and integrated Syria into the Mamluk kingdom. ${ }^{190}$

The Mamluks' sources of military manpower came from multiple areas. Their primary and most reliable source was men from now defunct Ayyubid principalities. The second was from a steady stream of refugees from Mongol territories. Some were actual Mongol tribesmen while others were indigenous Muslims, including mamluks, who had

\footnotetext{
${ }^{186}$ Amitai-Preiss, Mamluk-Ilkanid War, 45.

${ }^{187}$ Ibid. 2.

${ }^{188}$ Ibid. 2.

${ }^{189}$ The Bedouins controlled the fluctuating frontier with Ilkhanid Iraq; they conducted raids into Mongol territory; they acted as military auxiliaries and as scouts and intelligence gatherers. But, they could ally with the Mongols whenever they were dissatisfied with the sultan, see Amitai-Preiss, Mamluk-Ilkhanid War, 64.

190 The Ilkhanid war with the Golden Horde ensured the Mamluks that the Ilkhanids were fighting on at least two frontiers and could never concentrate their forces, see Amitai-Preiss, Mamluk-Ilkhanid War, 87.
} 
escaped Mongol control. ${ }^{191}$ Finally, the Mamluk sultan bought slaves and raised them to serve in his mamluk royal guard. They also acted as the backbone of his army. The sultan's amirs raised their own private forces, which included some mamluks. ${ }^{192}$

According to Amitai-Preiss, the Mamluks had numerous advantages over their Mongol enemy:

The Mamluks had the advantage of morale over the enemy. They were fighting (usually) on home territory, for their religion, their kingdom, and their lives. They were also defending their status as a ruling caste. To their mind, they had no choice but to win. The sultans did their best to inculcate these feelings in their followers. The Mongols may have been fighting for an abstract imperial ideal, for personal honor, and for booty, but they could not compete with the Mamluks for motivation. ${ }^{193}$

Direct interaction with the Mongols did not come until 1259-60, when the Ilkhan Hülegü sent envoys to Egypt. They delivered a letter to the Sultan Qutuz demanding his submission to the Ilkhanate. The letter contained verses from the Koran and was couched in Islamic terms, but the message was clearly Mongol: God [Tenggri] had given the Mongols the right to rule the world, therefore all should submit to them. Those who refused would be killed. Hülegü also insulted Qutuz's lowly origins as a mamluk. The Arabic author Ibn al-Furat stated that Hülegü's letter said the following: "He [Sultan Qutuz] is of the race of mamluks who fled before our [Mongol] sword into this [Egypt] country, who enjoyed its comforts and then killed its rulers [the Ayyubids]." ${ }^{, 194}$ But the threat in Hülegü's letter did not prompt Qutuz to submit. Instead, Qutuz received

\footnotetext{
${ }^{191}$ Amitai-Preiss, Mamluk-Ilkhanid War, 70-71.

192 Ibid. 72.

${ }^{193}$ Ibid. 234.

${ }^{194}$ Ibid. 36.
} 
permission from his amirs to execute the Mongol envoys. The envoys were cut in half and their heads were displayed at Bab al-Zuwayla in Cairo. ${ }^{195}$

\section{Benefits of an Anti-Mongol Stance}

The new Mamluk sultans saw the imminent Mongol threat as the chief means for shoring up their control over the Egyptian throne. Being a martial class, the Mamluk leaders argued that they were best equipped to handled the Mongol threat and that they should rule the kingdom. This type of justification was needed to quell any internal discord that still remained from Qutuz's controversial rise to power. According to AlJazari: "From the beginning of his reign, Qutuz had pursued an unequivocal anti-Mongol policy. He had used the need to resist the Mongols as the justification for his disposal of al-Mansur Ali b. Aybeg [leader of the Bahriyya] and his own accession to the throne (November 1259).",196

The military threat of the Mongols kept the Mamluks' main ruling system, that of the military, in practice and relevant. According to Linda Northrup:

The military crises of the thirteenth century had demanded discipline. Galvanized by the Mongol threat and the Crusader presence, the new Mamluk regime had insisted on hard training, slow promotion and gradual pay increases. Discipline had instilled a value system in which individual merit and achievement were eventually well rewarded and which made the early Mamluk army the strongest in the region at that time... ${ }^{197}$

\footnotetext{
195 Ibid. 36.

${ }^{196}$ Al-Jazari furthered stated: "The story is told that Qutuz claimed that he was descended from the Khwarazm-shah Ala al-Din Muhammad, and thus his emerging struggle with the Mongols also had an element of personal revenge in it," Al-Jazari, Hawadith al-zaman, quoted in Amitai-Preiss, MamlukIlkhanid War, 35.

${ }^{197}$ Linda Northrup, "The Bahri Mamluk sultanate," ed. Carl F. Petry, M.W. Daly, The Cambridge History of Egypt (Cambridge: Cambridge University Press, 1998), 261-62.
} 
This fierce discipline was accompanied by severe punishments and allowed the Mamluk sultan to rule his military and kingdom with an iron fist. One can see such examples in the actions of the general, and later Sultan, Baybars: "The [Mamluk] army reacted swiftly to the slightest rumor of a Mongol offensive and Baybars himself either led the troops or was right behind them. The continuing war also strengthened his rule, because in the face of the Mongol danger Baybars would brook no disloyalty." 198

When it came to clashes on the battlefield with the Mongols, the Mamluks proved their military prowess. Through numerous victories over the Mongols, who were thought invincible, the Mamluks exhibited that they could protect the kingdom and hence should continue to rule. The Mamluks' greatest victory over the Mongols came at Ayn Jalut (the Pools of Goliath), near Nazareth, on September 3, 1260. Upon hearing that Hülegü had pulled out the majority of his troops from Syria only leaving a small force under the general Kitbugha behind, the Mamluks decided to strike and attempt to dislodge the Mongols from Syria. In Vardan Arewelci's description of the battle, he attributed the Mongols' loss to their small numbers:

In the same year the army which the Il-khan Hulawu [Hülegü] had left to guard the land of Săm [Syria], about 20,000 men under the great general called Kitbuła [Kitbugha], a Christian by religion, was slaughtered in a battle against the Sultan of Egypt at the foot of Mount Tabor. He had a numberless multitude, and since the forces of [Kit-] Buła were few, they were slaughtered or taken captive. But some scattered and hid and escaped. They came to the king of Armenia, from whom they found great compassion; [he provided] clothing, horses, and money, so they returned gratefully to their lord, Tatars and Christians. ${ }^{199}$

The Mamluk advance force, under the command of Baybars, found Kitbugha's army near Tiberias in North Palestine and was joined there by Sultan Qutuz's main army.

\footnotetext{
${ }^{198}$ Amitai-Preiss, Mamluk-Ilkhanid War, 234.

${ }^{199}$ Vardan, Compilation, 218.
} 
Grigor of Akner gave a similar description of the battle, but with interesting facets of its

own:

Then Kitbuya [Kitbugha], who was the commander of the Tatar force, becoming overweening, went out to a place ten days journey from Jerusalem. Then the <doglike $>$ and lawless Egyptians, learning that the army of Tatars was living in unpreparedness, gathered their forces and with countless multitudes fell upon the Tatars, killed many of them, put many to flight, and captured many... ${ }^{200}$

The mamluk Sarim al-Din Uzbak witnessed the battle from the Mongol side and described it as a hard fought battle. The Mongols first broke the Egyptian left wing, but Sultan Qutuz rallied his troops and drove the Mongols onto marshy land. The Mongol commander Kitbugha was killed and the Mongols fled. They then made a stand at Baysan, but were defeated by Baybars. ${ }^{201}$ The battle was hard fought because the armies were of similar makeup and skill level: "The two armies confronting one another were similar in that their best troops were horse archers of Turco-Mongol stock, but in both cases this regular cavalry force was swollen by a larger body of men furnished by allies, tributaries, skirmishers, tribesmen fighting for the promise of booty."202

The true victory for the Mamluks was breaking the belief in Mongol invincibility on the battlefield. This was a huge morale boost for the Mamluks, proving the military might of the Bahri mamluks, and would prove to be a powerful tool in future negotiations with the Ilkhanid Mongols. ${ }^{203}$ When considering further benefits of the Mamluk victory at Ayn Jalut, scholarly opinions diverge. According to Robert Irwin, the Mamluk victory only saved the Mamluks for a time and it had not decided anything in the long term

\footnotetext{
${ }^{200}$ Grigor, Nation of Archers, 349.

${ }^{201}$ Irwin, The Early Mamluk Sultanate, 34.

202 Ibid. 34.

${ }^{203}$ Another Mamluk victory that bolstered Mamluk ruling legitimacy was the Battle of Homs on October 29/30, 1281, see Dashdondog, the Armenians, 175.
} 
because the Mongols returned to campaign in Syria in 1261, 1280, 1299, 1301, and $1303^{204}$

According to Northrup, the Mamluk victory at Ayn Jalut delivered Syria firmly into Mamluk hands. Syria before this had been divided among Ayyubid family members and although a treaty was signed in 1253 to break Ayyubid power, Ayn Jalut firmly confirmed Mamluk victory over the Ayyubids. ${ }^{205}$ A third theory came from David Saunders who argued that the battle of Ayn Jalut stopped Mongol expansion westward and saved Cairo. Saunders also said that it saved Islam in the region and stopped Christian restoration in the Near East. ${ }^{206}$ Only hindsight can offer an argument such as Saunders's. At the time, nothing was certain and the Mongol threat was still very real and immediate.

The Mamluks successfully utilized their past military victories against the Mongols to counter Mongol demands for submission, essentially stating that the Mongols could not make them submit because the Mongols could not defeat the Mamluks on the battlefield. The mentionings of past victories became a common and effective refrain in the diplomatic letters that passed back and forth between the Sultan and Ilkhan. After the Mongols' defeat at the battle of Homs in 1281, the Ilkhan Teguder sent an embassy to Cairo, demanding that Mamluk raids cease on Ilkhanid lands and for the sultan to submit. Teguder threatened that he would fight the sultan to expel him from Ilkhanid lands.

The Sultan Qalawun's letter of reply brought up two military thorns in the Ilkhanid side, Homs and Ayn Jalut, and avoided a direct answer to the demand for

${ }^{204}$ Irwin, The Early Mamluk Sultanate, 34.

${ }^{205}$ Northrup, "The Bahri Mamluk sultanate," 248.

${ }^{206}$ J.J. Saunders, A History of Medieval Islam (Routledge: London, 1993), 200. 
submission. Qalawun also ridiculed the Ilkhanid armies who had lost in Syria. ${ }^{207}$

Qalawun's answer was as follows: "You [Teguder] send us [Qalawun] word that if strife is not to cease between us, that we had better choose a battlefield, and that God will give victory to whom He will. Here is our answer: Those of your troops who survived their last defeat are not anxious to revisit the former battlefield. They fear to go there again to renew their misfortunes..."208 By the second Ilkhanid embassy to Egypt, the threat to fight the sultan was dropped.

This Mamluk confidence in their military continued throughout their interactions with the Ilkhanate. During the first campaign of the Ilkhan Ghazan in 1299 he dealt the Mamluks a military blow by defeating them in battle at Wadi al-Khaznadar (although it was a very costly victory for the Mongols). Despite this defeat, the Mamluks were still confident in their martial abilities and when Ghazan attempted to use his military victory in his diplomatic negotiations, the Mamluks successfully countered his demands and gloating. They did this by trumpeting their numerous victories against the Mongols in the past. According to Thomas Raff, the Mamluk sultan's courier, Husam ad-Din al-Mugiri, gave a rendition of the message he was entrusted to relate to Ghazan Khan after the Mamluks' defeat at Wadi al-Khaznadar. When baited with the question of why the Mamluks had fled the battlefield, Husam ad-Din al-Mugiri replied:

The army of the Tatars [Mongols] has been fleeing from us [Mamluks] for sixty years and we have fled only once... We did not flee from you for fear of your numbers or of your followers' strength but because we underestimated you... We have defeated you numerous times for a period of sixty years...So encountering you (on the field) continued to be the easiest thing possible for us... We set out against you with but a quarter of our armies because of our lack of concern for you. ${ }^{209}$

\footnotetext{
${ }^{207}$ Broadbridge, Kingship \& Ideology, 41-42.

${ }^{208}$ Northrup, "The Bahri Mamluk sultanate," 277.

${ }^{209}$ Husam ad-Din al-Mugiri, quoted in Raff, Remarks on an Anti-Mongol Fatwa, 9.
} 
Growing military power led to growing political power for the Mamluks. The Mamluks could and did successfully counter Mongol threats and kept the Mongols at bay. They also kept the Mongols from aiding their ally, the Armenians. One such example of this was after the Mamluk Sultan al-Ashraf sacked the Armenian city of Hromklay in 1292. The Ilkhan Geikhatu threatened the Sultan, stating that he would take Aleppo, and the Sultan countered by threatening to take Baghdad. The Sultan's threat kept Geikhatu in Baghdad and from aiding the Armenians. ${ }^{210}$

Another aspect of the Mongols that worked in the Mamluks' favor was that the Ilkhanid Mongols provided a clear example of the 'Other' and the infidel. This allowed the Mamluk sultans to direct their wars against the Mongols as holy wars, jihad, and to present themselves as the protectors and saviors of Islam. And as a military regime, the Mamluks needed to conduct jihad to maintain their legitimacy. Also, any connection to Islamic holy principles like jihad served to bolster the Mamluk regime, as well since Islam was the defining social force in Egypt. A good Muslim ruler, as the sultan should be, had to perform certain obligations for his people and God. In order to connect themselves with the past regimes and show themselves to be good Muslim rulers (and worthy of being Muslim rulers), the Mamluks took very seriously the importance of performing these vital functions. The sultan must protect his lands and subjects as a military guardian of Islam and uphold Islamic law (shariah). ${ }^{211}$ He must participate in military action against non-Muslim aggressors on behalf of Islam (jihad). ${ }^{212}$ The duty of

\footnotetext{
${ }^{210}$ Dashdondog, the Armenians, 186.

${ }^{211}$ Broadbridge, Kingship \& Ideology, 14-15.

${ }^{212}$ Ibid. 14-15.
} 
jihad had fallen into decline with the Ayyubid sultans, but the Mamluks were quick to revive this discarded combative ideal, as it was the mainstay of their ideology. ${ }^{213}$

The Armenians also provided a model of 'the Other' and the infidel for the Mamluks. The Mamluks fought the Christian knights in the Holy Land and they began their wars with the Armenians in 1259/60. The Armenians certainly saw the Islamic Mamluks as a threat to Christianity, as shown in Grigor's writings:

The Sultan, learning what the Armenian King's opinion was [to not surrender], sent many of his troops against the country of the Armenians by the route of Mari, while he himself took up his position in Xarxe. He ordered his army to go into the land, mercilessly to slaughter the Christians, destroy the churches and burn the buildings of towns and villages, to remain in the land fifteen days and take prisoners the women and children of the Christians, which they did. $^{214}$

The war with the Armenians offered another worthy and valuable jihad for the Mamluks, which they took advantage of:

[The Mamluks] burned the town of Sis, which was the seat of the Armenian kings. They cast wood into the fine and great church which was in the center of Sis and they burned it. They demolished the tombs of the kings. They killed many Christians and took many captives from the land and villages. After several days the Turkish [Mamluk] army, with much treasure and plunder, went to their own country, leaving the land of Armenia half ruined. ${ }^{215}$

Sultan al-Ashraf Khalil (r. 1290-1293) certainly took up this idea of utilizing the 'Other' for the justification of war. He defined his rule by martial conquest, expansion, and universal rule as the Guardian of Islam. Chief among his tasks was warring against infidels. This belligerent stance was clearly represented in his letters when he used heraldic titles such as 'Defeater of Infidels' and 'Annihilator of Franks, Armenians, and

\footnotetext{
${ }^{213}$ Ibid. 14-15.

${ }^{214}$ Grigor, Nation of Archers, 357.

${ }^{215}$ Ibid. 357-59.
} 
Mongols. ${ }^{216} \mathrm{He}$ was also careful to promote policies similar to past sultans, primarily his father, Qalawun, and Baybars, against the Mongols. Khalil had an easy job of gaining support for his campaigns against the Mongols because the Ilkhan Geikhatu was a pagan, i.e. infidel. This eliminated any complicating issues of religion. Khalil could easily show himself to be the Guardian of Islam. ${ }^{217}$ Prior to Geikhatu's reign (1291-1295) several of the Ilkhans had converted to Islam, which made the practice of conducting jihad much more complicated.

Despite the material destruction of Baghdad and the murder of the caliph, the Islamic Mamluks actually benefited from Baghdad's fall, along with the toppling of the Caliphate. The Sultan Baybars took the opportunity to establish a new Caliphate in Cairo in $1260-61 .^{218}$ The caliph became central to Mamluk kingship inside their lands since the Abbasid Caliphate sanctioned Mamluk rule. The caliph also preached jihad and called the Mamluks 'warriors of the faith,' mujahidun. ${ }^{219}$ Baybars attributed great importance to the establishment of the Caliphate in Cairo and sought to link himself to the caliph as much as possible. On Baybars's coins and inscriptions he called himself 'associate of the commander of the faithful.' This linked him with the head of his faith while making him look pious and humble by not calling himself the commander of the faithful. Ibn al-Furat wrote of how the caliph gave Baybars an investiture diploma (taglid) that confirmed Baybars as sultan. He then called on Baybars to conduct holy war (jihad) and he

\footnotetext{
${ }^{216}$ Broadbridge, Kingship \& Ideology, 49.

${ }^{217}$ Ibid. 46-47.

${ }^{218}$ Baybars's rule came about through an act of regicide, therefore he needed to establish strong support at home and create more legitimacy for his rule.

${ }^{219}$ Broadbridge, Kingship \& Ideology, 14-15.
} 
proclaimed Baybars the ruler of all lands of the Mamluk Sultanate and those lands under the infidel to be liberated. ${ }^{220}$

Although there was a significant drain on military manpower as a result of campaigns against the Mongols, the Mamluks found valuable and capable warriors for their army among disaffected or rebel Mongols. These units greatly improved the performance of the Mamluk military and certainly contributed to its long-term success: "The Kurdish, Turkoman, and Mongol tribal warriors who had joined the Mamluks in the turmoil accompanying the Mongol advance in the Middle East constituted the most valuable units of the Halqa."221 The Halqa consisted of freeborn cavalry soldiers of diverse provenance who served under the Mamluks. The Mamluks also aided rebel Mongols in their wars against the Ilkhanate, which was usually a benefit for them. One such example was Sulemish, who was an important Mongol general in Anatolia who rebelled in the winter of $1289-90$. The Mamluks promised to support him. Sulemish received support and even retreated to Cairo. Unfortunately, this particular venture did not work out for the Mamluks as Sulemish was quickly defeated by those he betrayed. ${ }^{222}$

Until 1295 the Mamluks primarily fought the Ilkhanate on the battlefield and in diplomacy. But from the Ilkhan Ghazan's conversion to Islam in 1295 forward, the Mamluks had to contend with the Mongols through religion. There had been Ilkhanid converts before this time, but they were not able to effect change within the Ilkhanate or threaten the Mamluks in any way with their conversion. Ghazan Khan (r. 1295 to 1304) established a strong Muslim legacy with his conversion to Islam and showed his

\footnotetext{
${ }^{220}$ Amitai-Preiss, Mamluk-Ilkhanid War, 57-59.

${ }^{221}$ Ulrich Haarmann, "Joseph's law- the careers and activities of Mamluk descendants before the Ottoman conquest of Egypt," ed. Thomas Philipp, Ulrich Haarmann, The Mamluks in Egyptian politics and society (Cambridge: Cambridge University Press, 1998), 63.

${ }^{222}$ Dashdondog, the Armenians, 122.
} 
commitment to his new religion by largely abandoning the title of 'Ilkhan' and adopting the Islamic title of 'Sultan' and 'Emperor of Islam.' He also toyed with the title 'Islamic centennial renewer. ${ }^{223}$

Interestingly, it was the Mongols who opened the door for the Mamluks to establish themselves as the protector and patron of Islam. According to Northrup:

As a consequence of the fall of Baghdad to the Mongols in 1258 and the transfer of the caliphate to Cairo, the sultan in Cairo had inherited Baghdad's political and religious role in the region as protector of the two holy cities in Arabia- Mecca and Medina... a responsibility which every sultan took seriously since it served to bolster claims to legitimacy. Thus the sultan sought to demonstrate his interest in the holy cities symbolically through the titulary, by sending each year with much pomp and ceremony the kiswa, or covering of the Kaba, by the construction and repair of monuments, and by making the pilgrimage when possible. ${ }^{224}$

In addition to the religious and symbolic power gained from being the patron of Islam, the Mamluks also received economic benefits: "The trade routes also carried pilgrim traffic to the holy sites. Though obliged to secure the safe passage of pilgrims, the sultan also benefited from the important revenue collected from them. The protection of these interests thus involved not only diplomacy but occasionally merited limited military intervention in quarrels between the rulers of the Hijaz."225

The Ilkhanate's conversion meant that the Mongols and Mamluks now had to compete for the same Islamic positions, titles, and honors available in the Islamic religious community. The two main honorifics were 'Patron of Islam' and 'Guardian of Islam.' By the late 1310 s, the Mongol and Mamluk rulers were chiefly competing for these titles and positions through political, material or diplomatic expressions of power.

\footnotetext{
${ }^{223}$ Ghazan's conversion to Islam around 1295 weakened the Ilkhans' link with the Great Khan and the Mongol tradition, see Gene R. Garthwaite, The Persians (Oxford: Blackwell Publishing, 2005), 141.

${ }^{224}$ Northrup, "The Bahri Mamluk sultanate," 282.

${ }^{225}$ Hijaz referred to the geographic area that contained the holy cities of Islam: Mecca, Medina, and Jerusalem, see Northrup, "The Bahri Mamluk sultanate," 282.
} 
The martial battlefield had faded. The holy cities of Arabia (the Hijaz) became central to the expressions of ideology between the Mongols and Mamluks. ${ }^{226}$ The Mamluks were successful in proving themselves the first patron of the Hijaz, forcing the Ilkhan Abu Said (1316-1335) to accept a secondary position. For a short time the Mamluks lost the upper hand in the Hijaz, but by 1333, the Sultan Muhammad (r. 1310-1340) had re-established his primacy in the Hijaz, despite Abu Said efforts. ${ }^{227}$ Any victory over the Mongols, especially religious, increased Mamluk power. As the Mamluks continued to rise, the Ilkhanate began to fade.

In addition to competing as the primary patron of Islam, the two superpowers of the Middle East also competed over which ruler, the Mamluk or Ilkhanid sultan, ruled by the virtues of a true Muslim king. The ability to show that he ruled by Islamic law and virtues greatly improved a sultan's image and power, as well as legitimacy. Both the Mamluks and the Ilkhanid sultans needed this legitimacy. Two important kingly virtues were justice tempered with mercy ${ }^{228}$ and obedience to God. The sultan also had to show that he was God's Chosen Ruler. 229

Finally, the Mamluks experienced material benefits from their adversarial stance against the Mongols. The threat of the Mongols in Syria compelled the majority of the Syrian factions to side with the Mamluks, thus the Mamluks gained these Syrian territories. ${ }^{230}$ Syria became and remained a permanent territory of the Mamluk kingdom long after the Ilkhanate had collapsed. Again, the actions of the Mongols had unintended consequences for the Mamluks, but ultimately to their benefit. In the realms of trade "the

\footnotetext{
${ }^{226}$ Broadbridge, Kingship \& Ideology, 97.

227 Ibid. 123.

${ }^{228}$ Ibid. 84.

229 Ibid. 68.

${ }^{230}$ Amitai-Preiss, Mamluk-Ilkhanid War, 47.
} 
expansion of the Mongols eventually opened up new trade routes with central Asia to supplement those linking Egypt to the east via the Red Sea: commercial links in the Mediterranean between Egypt and Latin crusades..."231 This was especially important for the Mamluks because Egypt depended on the trade of luxury goods for much of its material wealth and these goods came from India and the East. These routes then passed through Egypt and Syria to European markets.

The Mamluks also experienced a heightening of cultural and intellectual activity, as Cairo replaced fallen Baghdad as the principal center for the cultural activity of the Islamic Near East. ${ }^{232}$ According to Northrup: "The Egyptian capital functioned as a cultural magnet, attracting Muslim scholars and others from throughout the Near East, immigrants who lent a profoundly cosmopolitan air to Egyptian society, at least at its higher levels." ${ }^{, 233}$ This heightened culture would remain in the Mamluk kingdom and many of Islam's greatest treasures and achievements were created during the Mamluk period.

\section{Negative Effects of an Anti-Mongol Stance}

There were several major setbacks that the Mamluks experienced from their interactions with the Ilkhanid Mongols, the most serious of which threatened the Mamluks' continued existence as a ruling class and their control of the Sultanate. Throughout their rule, the Mamluks suffered from an extremely weak claim to the throne. This was clearly because of their origins as slaves. The Mamluks were ridiculed for their

\footnotetext{
${ }^{231}$ Northrup, "The Bahri Mamluk sultanate," 376.

232 Ibid. 376.

${ }^{233}$ Ibid. 376.
} 
slave origins, but they were also ridiculed for their absolute lack of proper or royal lineage. These shortcomings may have not been so debilitating if the foe the Mamluks pitted themselves against had a lesser lineage as well. Instead, the Mongols sported one of the strongest lineages in the Middle East during this time. It was based both on military prowess and well-established royal bloodlines. The Ilkhanate was still a symbol of Mongol prestige and carried the weight of the Chinggisid Divine Mandate. ${ }^{234}$

For the Mongols, the rule of the Mamluks was an affront to all those who ruled as a right of their noble blood. The Mamluks carried no royal blood and even worse, they were slaves and continued this slave system. Those who ruled as sultans in the Mamluk kingdom had began their careers as slaves and only those who had been slaves, mamluks, were eligible to rule according to the Mamluk sultanate system. For the Mongols, a ruling and military system based on slaves was perverse and could only be weak and ineffectual. Other nomads and Mongolians were enslaved during Chinggis's reign and were incorporated into a hereditary system of slavery (ötegü boghul); slavery was the condition of lesser people. ${ }^{235}$ The Mamluks did have some understanding of this type of slavery, since they were of Turkish Kipchak origin and such slavery was typical in nomadic societies.

The Mongols and their allies the Armenians insulted and degraded the Mamluk sultans during most of their diplomatic interactions. When Hülegü demanded the submission of the Mamluk Sultan Qutuz in 1260, Hülegü denigrated Qutuz for his servile origins. Hülegü's Armenian ally, Hetum I, called the Sultan Baybars a dog and slave and refused to deal with him. Grigor related one version of this event: "On his way to Egypt

\footnotetext{
${ }^{234}$ Broadbridge, Kingship \& Ideology, 13.

235 Ibid. 13.
} 
the Sultan of Egypt died and they appointed Pntuxtar [Baybars] Sultan of Egypt. Having heard this, the King of the Armenians called him a $<\mathrm{dog}>$ and a slave."236

Grigor described another episode, which related the diplomatic tensions between the Mamluks and Armenians. In this episode, the Mamluk Sultan Baybars harassed the Armenian prince, Lewon, the first son of Hetum I. Lewon at this time was in Mamluk custody after being captured in battle:

After this the Sultan spoke to Lewon and said, 'Your father called me a slave and would not make peace. Am I the slave now, or you?' He said this and many other words of reproach to the King's son, and then thereafter he greatly honored him and showed him affection, uttering words of comfort, not to fear anything, but to remain cheerful for some days and then he would send him back to his father the King of the Armenians. With these words the Sultan Pntuxtar [Baybars] sent Baron Lewon to Egypt. ${ }^{237}$

The fact that the Armenians could use such an insult against the Mamluks must have infuriated the Mamluks and further eroded their ruling legitimacy. In his letters to the Mamluk Sultan Qalawun in 1299-1300, the Ilkhan Ghazan showed his disdain for the mamluk slaves and their lack of lineage. He labeled them as the lowest race, min ardhal al-ajnas. ${ }^{238}$ This was clearly an issue of great insult to the Mongols throughout their rule in the Ilkhanate and a consistent and effective means of quickly establishing their political superiority over the Mamluks.

The Mamluks sought to compensate for their political weakness and concurrently counter the threat posed by the Ilkhanid's bloodline through a variety of means. The most interesting policy was the Mamluk attempts to marry into the Chinggisid line. Irwin stated: "[the fact that] the Mongols still retained their social prestige is indicated by the

\footnotetext{
${ }^{236}$ Grigor, Nation of Archers, 390.

${ }^{237}$ Ibid. 359.

${ }^{238}$ Broadbridge, Kingship \& Ideology, 79.
} 
series of missions sent by the Sultan to the lands of the Golden Horde to secure a Mongol princess. In the end [Sultan] al-Nasir Muhammad did briefly marry Tulubiyya, a greatgreat-grand-daughter of Chingiz Khan."239 This marriage arrangement clearly shows the Mamluk desire to link into the Chinggisid line, albeit through their relationship with the Golden Horde. Despite being an adversary, the Mamluks still sought several marriage arrangements with the Ilkhanate, as illustrated in the negotiations conducted by the last Ilkhan Abu Said. Choban, the regent of Abu Said, sought policies to increase Mongol power, particularly through his style of negotiating marriages. He mostly showed his power against the Mamluk ambassadors by declining their marriage proposals, which showed great insult to the sultan. ${ }^{240}$

The second greatest threat the Ilkhanids posed to the Mamluk ruling system was in their conversion to Islam. The Mamluks now had a new contender for the title of 'Guardian (Protector) of Islam' and 'the Patron of Islam.' During the years of Mongol shamanist rule in Iran, the older Islamic models of legitimacy were not utilized as much. When the Ilkhans converted to Islam there was a fusion of Mongol and Islamic ruling traditions. They ruled both as divinely favored descendants of Chinggis Khan as well as Muslim sultans who were advised by Islamic scholars. Some Mongol rulers liked aspects of Islamic kingship. ${ }^{241}$ The Ilkhan Teguder (r. 1282-1284) converted to Islam and took the name Ahmad and the title of 'Sultan.' This conversion and subsequent ones destroyed the Mamluks' main case for their rule: that the Ilkhanate was an infidel oppressor and the Mamluks were the protectors of Muslim society and the Guardian of Islam. ${ }^{242}$ Beginning

\footnotetext{
${ }^{239}$ Irwin, The Early Mamluk Sultanate, 108.

${ }^{240}$ Broadbridge, Kingship \& Ideology, 114-15.

${ }^{241}$ Ibid. 10-11.

242 Ibid. 64.
} 
with the reign of Teguder the Ilkhans vacillated between Muslim and Pagan leadership. Ghazan ruled as a Muslim and called himself the Guardian of Islam, making a direct challenge to the Mamluk sultan. Ghazan was also the first Ilkhanid ruler to break with the Mongol tradition of secret burial for the khan. Instead he built an Islamic mausoleum. ${ }^{243}$

The Ilkhan Oljeitu (r. 1304-1316) continued his brother Ghazan's Islamic legacy upon his accession to the throne. Oljeitu's birth name was Islamic, Muhammad Kharbandah, and he adopted the title of 'Sultan.' Also upon his accession, he took the regnal title 'Oljeitu,' meaning 'Auspicious.' Oljeitu upheld Ghazan's laws, despised the Abbasid Caliph, and believed in his legitimacy through his descent from Chinggis Khan. Oljeitu's diplomatic letters still referred to the Enduring Sky (Tenggri) as God. ${ }^{244}$ Oljeitu himself religiously experimented before finally accepting Shia Islam, ${ }^{245}$ while his successor, Abu Said, was a Sunni Muslim.

When the Ilkhan Teguder demanded submission from the Sultan Qalawun in September 1282, his letter and ambassador were very much influenced by Islamic principles. His second embassy to the Mamluk Sultanate was led by his spiritual leader Shaykh Abd al-Rahman as requested by Qalawun. Teguder's letter asked only for a peaceful agreement and not submission, but his letter was not taken well as Qalawun treated the Mongol diplomats poorly after the message was heard. The Sultan kept the diplomats imprisoned and al-Rahman died in Mamluk hands. ${ }^{246}$

In both his letters and actions, Teguder was a rival to Qalawun as a virtuous Muslim ruler. Teguder stated that he had done the following as a virtuous Muslim ruler:

\footnotetext{
243 Ibid. 64.

244 Ibid. 94.

${ }^{245}$ Irwin, The Early Mamluk Sultanate, 118.

${ }^{246}$ Broadbridge, Kingship \& Ideology, 43.
} 
established Islamic law; pardoned criminals; inspected Islamic endowments; constructed new religious buildings; and regularized protection for pilgrimage caravans. Teguder was an especial threat to Qalawun's legitimacy because he founded holy buildings and acted as a protective sovereign over the holy cities and pilgrimages. ${ }^{247}$ Great tensions were also created in the patronage of the Hijaz when the regent Choban acted independently of the Ilkhan Abu Said and pursued policies to increase Mongol power and promote his belief in Mongol supremacy by conducting great building programs in Mecca and Medina. This certainly aggravated the Mamluks. ${ }^{248}$ Ghazan's letters took a different approach. He used Islamic religious thought to construct his argument that the Mamluks should submit to the Mongols. His argument stated that since the Ilkhan was now a Muslim, the Mongols and Mamluks were fellow brothers, and the Mamluks had nothing to fear in joining the Ilkhan's subjects. Ghazan implied that he would restore rule to kings rather than it remain with slaves, i.e. the Mamluks. ${ }^{249}$

The Mamluks countered the Mongol threat to their political superiority in the Hijaz by proclaiming religious superiority as a result of their earlier conversion to Islam. The Mamluk Sultan Muhammad proclaimed himself 'first among Muslim equals. ${ }^{250}$ Muhammad's argument was that the Mamluks had been practicing Muslims for a much longer time than the Mongols and therefore could offer sounder religious guidance and protection to the lands of Islam, the Dar al-Islam. The Sultan Qalawun also utilized the concept of precedence in conversion to counter the Ilkhan Teguder's demand for

\footnotetext{
${ }^{247}$ Ibid. $39-40$.

248 Ibid. 114-15.

${ }^{249}$ Ibid. 64.

${ }^{250}$ Ibid. 100.
} 
submission. ${ }^{251}$ Since Qalawun had converted to Islam first, he was senior in religion to Teguder; therefore Teguder could not make such demands of Qalawun. It also meant that as a senior in religion, Qalawun was more fit to rule (and to keep his position) than Teguder. The Mamluks encountered this religious threat in the 1320 s and the first half of the 1330 s because as the weakening Ilkhanid military ceased to be a threat to the Mamluks, the Ilkhans sought different avenues to challenge the power of the Mamluk sultans. The Ilkhans pursued the mantle of the primary religious patron of the Islamic world, a title long held by the Mamluk sultans, ${ }^{252}$ but ultimately failed in this venture. During the reigns of the first Muslim Ilkhans, the Mamluk sultans found it most effective to attack the Ilkhans' sincerity in their conversions to Islam. According to Ibn Abd al-Zathir, who was a historian and head chancery official of Baybars and Qalawun, Teguder's conversion was fake and he was portrayed as a false convert. ${ }^{253}$ But by the time of the Ilkhan Ghazan, the Mamluks found more success in combating the Mongols by proving that the Ilkhan was not a good Muslim ruler, instead of refuting his conversion. ${ }^{254}$ The Mamluks refuted Ghazan's statement of having God's support by saying that Ghazan was misguided for claiming God's approval and that God actually supported the Mamluks. ${ }^{255}$

An even more potent threat to the Mamluks was when the Ilkhanid Mongols combined Islam with their superior Chinggisid lineage. In Ghazan Khan's letters to the sultan, written around his October 1299 campaign into Syria and his victory at the battle of Wadi al-Khaznadar, he expressed the superiority of his Chinggisid heritage by

\footnotetext{
${ }^{251}$ Ibid. 40.

252 Ibid. 109.

${ }^{253}$ Ibid. 42.

${ }^{254}$ Ibid. 80.

${ }^{255}$ Ibid. 84.
} 
utilizing Islamic chancery practices and conventions. The utilization of both Islamic and Mongol symbols allowed the Ilkhans to combat both the Mamluks and other peoples on superior ideological grounds. ${ }^{256}$ This double utilization occurred on some of Ghazan's minted coins; some had both Mongolian and Arabic names for God, Tenggri and Allah. $^{257}$

Ghazan provides a good example of this double utilization. As a Muslim, Ghazan stated that he was the 'divinely chosen arbiter of justice' and as such he could give authority to those he chose. Ghazan said that God bestowed royal authority on Chinggis Khan and that he was the sixth in this illustrious line. ${ }^{258}$ This belief perfectly melded the two ideologies. Ghazan boasted the prestige of his bloodline, while showing that the Islamic God favored Chinggis Khan. Ghazan was an appropriate ruler on both accounts.

Another negative consequence of the Mamluks' wars with the Ilkhanate was the threat and actual loss of some of their Ayyubid allies. Sunqur al-Ashqar, the viceroy of Damascus, went against the Sultan Qalawun and declared his ruling independence in Damasacus. The Mongols under the general Mongke Temur and their Armenian allies took advantage of the fight between Qalawun and Sunqur al-Ashqar, possibly at Sunqur's urging, and sacked Aleppo in 1260. But the Mamluks were politically victorious in regaining Sunqur's allegiance and Mongol progress was stopped at the battle of Homs in 1281. ${ }^{259}$ Other difficult Ayyubid princes included Al-Nasir Yusuf, who continually vacillated his support, and Al-Mughith Umar of Karak, who was accused of treating with the Mongols. The Mamluks also had to contend with other weak links in the region,

\footnotetext{
${ }^{256}$ The usage of Mongolian ideas and terms in letters addressed to the Mamluks often weakened Ghazan's position as a Muslim, so his ideas were put into Islamic terms, see Broadbridge, Kingship \& Ideology, 84.

${ }^{257}$ Broadbridge, Kingship \& Ideology, 66.

258 Ibid. 79.

${ }^{259}$ Northrup, "The Bahri Mamluk sultanate," 274-75.
} 
namely Bohemond VI of Antioch-Tripoli, who was connected to the Cilician Armenian family through marriage, hence he allied with Armenia and the Mongols. ${ }^{260}$

Additionally, circumstances that began as advantageous for the Mamluks quickly proved to be of a more duplicitous nature. The Mamluks gained numerous highly skilled Mongol warriors, who were either rebels from the Ilkhanid army or displaced refugee nomadic peoples pushed into Mamluk territory. These refugees began arriving in late 1261 from Hülegü's army. ${ }^{261}$ These Mongols were incorporated into the Mamluks' second most talented military unit, the Wafidiyya, and proved their fighting abilities. But some of these Mongol units created political turmoil in the Mamluk army. One such example occurred in the winter of 1299 , when Ghazan Khan crossed the Euphrates River with a mixed army of Mongols, Armenians and Georgians, along with the Mamluk emirs Qibjaq and Baktimur. While on their way against Ghazan's army, the Mamluk army was thrown into turmoil by a rebellious plot hatched by the Mongol Oirat Wafidiyya. They planned to murder the sultan and his officers and put the Mongol mamluk Kitbugha back on the sultan's throne. ${ }^{262}$ Although this plot was foiled and hundreds of Oirats were killed, it showed the military disasters that could occur when dealing with Mongol dissidents.

The Ilkhanate also presented a significant threat to Egyptian commercial interests and their presence negatively impacted the operations of the Mamluk Sultanate. To what extent the Ilkhanate's actions crippled the Sultanate is less clear. The Ilkhanate's operations in Cilician Armenia significantly threatened the Mamluks' access to the mamluk slave-trading region in the Black Sea. As Northrup explained:

\footnotetext{
${ }^{260}$ Ibid. 274.

${ }^{261}$ Amitai-Preiss, Mamluk-Ilkhanid War, 106.

${ }^{262}$ Irwin, The Early Mamluk Sultanate, 99-100.
} 
Critical...was the threat posed to the slave trade, vital to the existence of the Mamluk regime, which was conducted along routes passing through Mongol territory. Increasingly this concern became intertwined with the competition in the region for the east-west trade. Indeed, it is clear that commercial concerns underlay much of Mamluk diplomatic and even military activity during the Bahri period. ${ }^{263}$

The initial Mongol conquest and the subsequent re-conquest by Hülegü created a vast new trade zone, which ran through the newly established Ilkhanate. There were two main routes that concerned the Ilkhans. The more established route was the southern sea route, which linked eastern lands via the Indian Ocean, the Red Sea, and the Nile with the Mediterranean. ${ }^{264}$ These southern sealanes were often under the control of the Mamluks and the Mamluk sultans struggled to maintain controll over this southern route from which they stood to reap large benefits. ${ }^{265}$ The second route was a more northerly route, which became an attractive alternative to the southern route and had the potential to undercut the Mamluks' southerly route. The Ilkhanate owned this northerly route, along with their Genoese allies, and competed with the Mamluk routes for a century after the initial Mongol conquest. The Ilkhanids allowed the Genoese access to the eastern oceans, but the Ilkhans were also involved in the region. The Ilkhan Arghun created a naval fleet in Baghdad with the intention of seizing the Mamluks' shipping lanes in the Red Sea. ${ }^{266}$

Issues of trade and religious patronage merged to create a prolonged conflict between the Ilkhanids and the Mamluks in the Arabian Peninsula. Northrup provided an explanation of this conflict and its importance in the overall Mongol-Mamluk rivalry:

In 1315-16, if not earlier, the Ilkhanids became involved in local rivalries in Mecca and sought to use them, just as the Mamluks did, to exert

\footnotetext{
${ }^{263}$ Northrup, "The Bahri Mamluk sultanate," 277-78.

264 Ibid. 283.

265 Ibid. 277-78.

${ }^{266}$ Dashdondog, the Armenians, 181.
} 
influence. Though an effort to conquer the Hijaz by the sharif of $\mathrm{Mecca}^{267}$ with a force furnished by the Ilkhan Oljeitu failed, the sharif did capture Mecca with Mongol assistance two years later, whereupon the name of the Ilkhan Abu Said (1316-35) was mentioned in the khutba. ${ }^{268}$ Underlying religious and political interests in the region, therefore, was the imperative to protect the Sultanate's commercial interests in the lands of the Red Sea basin (Arabia, Upper Egypt and Nubia, Ethiopia) and the Indian Ocean (e.g. Ceylon, Sind, Hind, China). Mamluk diplomatic and military activities in these lands must be viewed, therefore, at least partially in the light of these concerns. ${ }^{269}$

Finally, the Ilkhanate created a rather difficult situation for the Mamluks when the Ilkhanate collapsed in 1335. The Mamluks' greatest enemy had dissipated, which left this military regime without an external threat. The Mamluks, as a military regime, needed a strong external enemy to continually justify their presence and rule. It was clear by the 1320 s and 1330 s that the Ilkhanate no longer posed a military threat to the Mamluks. With no strong enemy to face and the coming of a period of relative peace, the Mamluk military structure became lax and the Mamluk ruling elite lost power. Finally, "[with] the disintegration of the Ilkhanid state...the Bahri regime entered a period of peace, prosperity and internal stability. The military ethic that had served so well during a time of crisis began to deteriorate...,270 Despite this setback, the Mamluks continued to rule Egypt for another two hundred years, until 1517.

In summarizing the above evidence, it was clear that the Mamluks experienced many more positive consequences from their stance against the Ilkhanid Mongols. On first consideration this notion may seem surprising as the prevailing viewpoint of the time was that the Mongols were the most powerful and successful force in the region and it

\footnotetext{
${ }^{267}$ Carl F. Petry, ed., The Cambridge History of Islam, Vol I, 640-1517 (Cambridge: Cambridge University Press, 1998), 537.

${ }_{268}$ The khutba/khutab was the sermon preached by the khatib in mosques at Friday noon prayer; also the acknowledgement of the Caliph or ruler, see Petry, The Cambridge History of Islam, 531.

${ }^{269}$ Northrup, "The Bahri Mamluk sultanate," 283.

${ }^{270}$ Ibid. 261-62.
} 
was presumed that they would continue in this role. No one expected the Mamluks to defeat the Mongols at Ayn Jalut and to ultimately outlast the Ilkhanate.

The Mamluk sultans quickly realized the benefit of the Mongol menace, utilizing its threat as a way to solidify their ruling legitimacy. This was especially important since the Mamluks had just taken the Egyptian throne. The Mamluks also actively attacked the religious legitimacy of the Ilkhanate, both before and after the Ilkhans' conversion to Islam. This helped the Mamluks boast of their Islamic virtues and their re-establishement of the Caliphate in Cairo assured the Caliph's support of the Mamluk rulers.

Some of the negative effects the Mamluks experienced from the Mongols included material losses, the loss of life and allies, the loss of territory and commerce, but most importantly, the great loss of ruling legitimacy and the continued weakness of their bloodline in comparison to the Chinggisids. Although it was a long hard-fought war against the Ilkhanate, the Mamluks were able to stop the Mongol advance. Still more amazing was that the Mamluks were able to capitalize on their victories over the Ilkhanate which propelled them to military supremacy in the Middle East. The Mamluks' continual resistance and pressure on the Mongols assisted in the collapse of the Ilkhanate in 1335. The Mamluks then sealed their revenge against the Kingdom of Cilician Armenia with its complete conquest in 1375. 


\section{CONCLUSION}

This thesis sought to address a gap in the available academic literature on the Mongol presence in the Middle East and relations between the Ilkhanate and its neighbors. Some research was available on the relationship between the Mongols and the Mamluks; the Mamluks and Armenians; and the Mongols and the Armenians. There was no source dedicated directly to the study of the Ilkhanid-Armenian-Mamluk relationship. The study of this trifold relationship yielded numerous unique insights into the Ilkhanid presence in the Middle East, as well as the Mamluk relationship with the Ilkhanate and Armenia. This work sought to show this trifold relationship as a phenomenon of its own and as an adequate framework through which to study the medieval Middle East. It ultimately sought to provide calculations of advantages and disadvantages for both the Armenians and Mamluks in regards to their relationships with the Ilkhanid Mongols. The conclusion was that the benefits the Mamluks gained from being adversaries of the Ilkhanid Mongols far outweighed the negative consequences. Whereas with the Armenians, their alliance with the Mongol proved overwhelmingly negative.

Owing to the comparative and expansive nature of the topic, this thesis utilized a plethora of different primary sources, including sources in Armenian, Persian, Arabic, and Syriac. All of these works were studied through English translations, both in complete translations and partial translations found in secondary sources. The major contemporary Armenian authors included Grigor of Akner, Kirakos of Ganjak, and 
Varden Arewelci. The major Persian authors included Juwayni, Rashid al-Din, Nasir alDin Tusi, and Juzjani. The most important Arabic authors for the thesis were Ibn al-Athir followed by Ibn Abd al-Zathir and Baybars al-Mansuri.

The primary sources from the period studied, 1220-1335, clearly exhibited relationships among the Ilkhanid Mongols, the Armenians, and the Egyptian Mamluks. When the Mongols arrived in Persia, they seemed unstoppable. The peoples the Mongols encountered had to decide how they would deal with this new power player in the region. The Armenians, from Greater Armenia and Cilician Armenia, submitted to the Mongols and became Mongol vassals. The Mamluks chose an adversarial stance and were successful in repelling the Mongols. All three groups received political benefits from their relations with the other two. Such benefits included monetary and territorial gains, religious or political freedoms, and military protection, to name a few. Each relationship also bore its share of negative effects, from the mundane to catastrophic.

The Ilkhanid Mongols' relations with the Armenians and Mamluks were shaped by the concept of the Divine Mandate: the Mongol belief that God (Tenggri) had ordained that the Mongols would rule the world. As such, the Mongols were God's Chosen and they served God's will through their conquests. Any people who resisted the Mongols were resisting God's will. This labeled them as both rebels and heretics. Also as a result of the Divine Mandate, the Mongols conceived of the world in a "conqueror and conquered' mentality in which the Mongols were always the superior force. It also meant that other peoples were seen in two ways, those who submitted to the Mongols and those yet to submit, i.e. enemies. This framework worked well with the Armenians because they had submitted to the Mongols and served their new masters well. Unfortunately, the 
Mamluks greatly challenged this framework, because the Mongols could never conquer them.

There were several significant benefits the Mongols' enemies could receive if they submitted. The submitted kingdom/nobles could receive their lands back as well as receive additional land. They could also receive local jurisdiction over their lands if they provided consistent taxes to the Mongols. Another important benefit was the conveying of official pardons, which meant that those who submitted could not be prosecuted for their previous belligerent stance. Additionally, those who submitted could receive greater political benefits over their local or regional rivals, as well as possible political marriages to Mongol princesses and desirable military service and accolades. The Mongols also offered religious tolerance and promoted individuals through merit and loyal service with less emphasis on blood relations. The last extremely valuable benefit was the military protection offered by the Mongols.

For the Greater Armenians and Cilician Armenians, their relationship with the Ilkhanid Mongols proved to be overwhelmingly negative. Much of the failure of the Armenian-Ilkhanid alliance hinged on the Mongols' inability to offer adequate military protection to the Armenians. The Mamluks were able to conduct numerous devastating raids on the Cilician-Armenians and ultimately crushed the Kingdom of Cilician Armenia. The Golden Horde and rebel Mongols were able to devastate the lands of Greater Armenia. Additonally, the Armenians had to provide substantial material and personnel support to the Mongols, which greatly weakened the Armenians' defenses and economies. In addition to great material losses, the Armenians also experienced great losses in human life, particularly the nobility and soldiery. 
For the Mamluks, their relationship as an enemy of the Ilkhanid Mongols proved overly advantageous and greatly aided in the meteoric rise of the Mamluks as a powerful kingdom. The threat of the Mongols pushed the Mamluk political factions to a unified purpose: to defend the kingdom. The Mamluks, who had just stolen the Egyptian throne, were able to solidify their control over the throne by justifiying the need for a martial ruling class to resist the Mongols. The continual threat of the Mongols in Syria kept the Mamluks on the Egyptian throne. Their numerous military victories against the 'unstoppable' Mongols also secured their position. The Mamluks were able to gain further ruling legitimacy by re-establishing the Caliphate in Cairo; becoming the protectors of Islam; and being the defenders of the faith through jihad against the infidels, i.e. the Mongols and Armenians.

Ultimately this thesis aimed to show that the study of any one of these three groups during the thirteenth century must include an understanding of how these three groups, the Ilkhanid Mongols, Armenians, and Mamluks, were connected. The Mamluks came into their own fighting against the Mongols and became a mighty power that ruled Egypt until 1517. The Kingdom of Cilician Armenia fell in 1375 as a result of Mamluk attacks. Perhaps surprisingly, the Ilkhanate was the first to collapse in 1335 . Although the Ilkhanate had a short existence, it shaped the Middle East in unexpected ways, especially through its relationships with the Armenians and Mamluks. The Ilkhanate stood as a complex society that maintained much of its Mongol character while being intimately intertwined with the rest of the Middle East, contributing significantly to the history of the region. 


\section{REFERENCES}

\section{Primary Sources}

Anonymous. The Secret History of the Mongols. Translated by Francis Woodman Cleaves. Cambridge, MA: Cambridge University Press, 1982.

Anonymous. The Medieval Armenian Adaptation of the Georgian Chronicles: The Original Georgian Texts and the Armenian Adaptation. Translated by Robert W. Thomson. Oxford: Clarendon Press, 1996.

Bar Hebraeus. Chronicon Syriacum and The Chronography of Gregory Abu'l Faraj. Translated by E.A. Wallis Budge. Oxford and London, 1932.

Baybars al-Mansuri. Zubdat al-fikra fitarik al-hijra history of the early Mamluk period. Translated by Donald S. Richards. Bibliotheca Islamica, Bd. 42. Berlin: Das Arab. Buch, 1998.

Grigor of Akner. History of the Nation of Archers (the Mongols). Translated by Robert P. Blake, Richard N. Frye. HJAS 12:3/4 (December 1949): 269-399.

Ibn al-Athir. Al-Kämil fil-tarikh, Part 3, The Years 589-629/1193-1231, The Ayyubids after Saladin and the Mongol Menace. Translated by D.S. Richards. Aldershot: Ashgate Publishing Limited, 2008.

Ala-ad-Din Ata-Malik Juwayni. The History of the World Conqueror. Translated by John Andrew Boyle. Cambridge, MA: Harvard University Press, 1958.

Minhaj Siraj Juzjani. Ghaznivide, Ghor, and slave dynasties, or, Tabakat-i Nasiri of Minhaju-s Siraj. Translated by John Dawson. Calcutta: S. Gupta, 1953. 
Kirakos of Ganjak. Patmutiwn Hayots (History of the Armenians). Translated by John Andrew Boyle. Central Asiatic Journal, Vol. 3, No. 3, 1963.

Taqi al-Din Ahmad al-Maqrizi. A History of the Ayyubid Sultans of Egypt. Translated by R.J.C. Broadhurst. Library of Classical Arabic Literature, vol. 5. Boston: Twayne Publishers, 1980.

Rashid al-Din. A Compendium of Chronicles. Translated by Sheila Blair. Oxford: Oxford University Press, 1995.

Rashid al-Din. The Successors of Genghis Khan. Translated by John Andrew Boyle. New York: Columbia University Press, 1971.

Vardan Arewelci. The Historical Compilation. Translated by Robert W. Thomson. Washington, D.C.: Dumbarton Oaks Research Library and Collection, 1989.

\section{Secondary Sources}

Alemany, Agusti. Sources of the Alans: a critical compilation. Boston: Brill, 2000.

Allsen, Thomas T. Mongol Imperialism: The Policies of the Gran Qan Möngke in China, Russia, and the Islamic Lands, 1251-59. Berkeley: University of California Press, 1987.

Amitai, Reuven. The Mongols in the Islamic Lands: studies in the history of the Ilkhanate. Burlington, VT: Ashgate/Variorum, 2007.

Amitai, Reuven. Mongols, Turks, and others: Eurasian nomads and the sedentary world. Boston: Brill, 2005.

Amitai-Preiss, Reuven. "Ghazan, Islam and Mongol Tradition: A View from the Mamluk sultanate." Bulletin of the School of Oriental and African Studies, University of London 59, 1, 1996.

Amitai-Preiss, Reuven. Mongols and Mamluks: The Mamluk-Ilkhanid War, 1260-81. Cambridge: Cambridge University Press, 1995. 
Bedrosian, Robert Gregory. The Turco-Mongol Invasions and the Lords of Armenia in the 13-14 ${ }^{\text {th }}$ centuries. Thesis (PhD) Columbia University, 1979.

Broadbridge, Anne F. Kingship and Ideology in the Islamic and Mongol Worlds. Cambridge: Cambridge University Press, 2008.

Chahin, M. The Kingdom of Armenia. London: Croom Helm, 1987.

Dashdondog, Bayarsaikhan. The Mongols and the Armenians (1220-1335). Boston: Brill, 2011.

Fisher, W.B. et all, eds. The Cambridge History of Iran. Cambridge: Cambridge University Press, 1968-1991.

Garsoïan, Nina G. Church and Culture in Early Medieval Armenia. Aldershot: Ashgate Publishing, 1999.

Garthwaite, Gene R. The Persians. Oxford: Blackwell Publishing, 2005.

Gervers, Michael and Ramzi Jibran Bikhazi. Conversion and continuity: indigenous Christian communities in Islamic lands, eighth to eighteenth centuries. Toronto: Pontifical Institute of Medieval Studies, 1990.

Gervers, Michael and James M Powell. Tolerance and intolerance: social conflict in the age of the Crusades. Syracuse, NY: Syracuse University Press, 2001.

Glubb, Sir John. Soldiers of Fortune: The Story of the Mamlukes. New York: Stein and Day Publishers, 1973.

Holt, P.M., Ann K.S. Lambton, and Bernard Lewis, eds. The Cambridge History of Islam Vol I, the Central Islamic Lands. Cambridge: Cambridge University Press, 1970.

Holt, P.M., Ann K.S. Lambton, and Bernard Lewis, eds. The Cambridge History of Islam Vol 2, the Further Islamic Lands, Islamic Society and Civilization. Cambridge: Cambridge University Press, 1970. 
Hussey, J.M. Cambridge Medieval History, Vol. IV the Byzantine Empire: Byzantium and its neighbors. Cambridge: Cambridge University Press, 1966.

Irwin, Robert. The Middle East in the Middle Ages: The Early Mamluk Sultanate 12501382. Carbondale, 1986.

Lane, George. Early Mongol rule in the thirteenth century Iran: a Persian Renaissance. New York: RoutledgeCurzon, 2003.

Lane-Poole, Stanley. A History of Egypt in the Middle Ages, second edition revised. London: Methuen \& Co. Ltd, 1913.

Minorsky, V. The Turks, Iran and the Caucasus in the Middle Ages. London: Variorum, 1978.

Petry, Carl F. and M.W. Daly, eds. The Cambridge History of Egypt. Cambridge: Cambridge University Press, 1998.

Petry, Carl F., ed. The Cambridge History of Islam, Vol I, 640-1517. Cambridge: Cambridge University Press, 1998.

Philipp, Thomas and Ulrich Haarmann. The Mamluks in Egyptian politics and society. Cambridge: Cambridge University Press, 1998.

Raff, Thomas. Remarks on an Anti-Mongol Fatwa by Ibn Taimiya. Leiden, 1973.

Redgate, A.E. The Armenians. Oxford: Blackwell Publishers, 1999.

Redgate, A.E. "Myth and Reality: Armenian Identity in the early Middle Ages." National Identities, 9, no. 4 (2007): 281-306.

Samuelian, Thomas J. and Michael E. Stone, eds. Medieval Armenian Culture. Chico, CA: Scholars Press, 1984.

Saunders, J.J. A History of Medieval Islam. London: Routledge, 1993. 
Saunders, J.J. The History of the Mongol Conquests. New York: Barnes \& Noble Publishers, 1971.

Spuler, Bertold. History of the Mongols Based on Eastern and Western Accounts of the Thirteenth and Fourteenth Centuries. Translated by Helga and Stuart Drummond. Berkeley: University of California Press, 1972.

Stewart, Angus Donal. The Armenian Kingdom and the Mamluks: War and Diplomacy during the Reigns of Hetum II (1289-1307). Leiden, 2001.

Turnbull, Stephen. Genghis Khan and the Mongol Conquests, 1190-1400. New York: Routledge, 2003.

Winter, Michael and Amalia Levanoni. The Mamluks in Egyptian and Syrian politics and society. Boston: Brill, 2004. 


\section{APPENDIX}

Reigns of the Rulers of the Ilkhanate, the Kingdom of Cilician Armenia, and the Mamluk

Kingdom of Egypt

\begin{tabular}{ll}
$\begin{array}{l}\text { Mongol Rulers of the Ilkhanate } \\
\text { Reign }\end{array}$ & Rulers \\
\hline $1256-1265$ & Hülegü \\
$1265-1282$ & Abaqa \\
$1282-1284$ & Ahmad Teguder \\
$1284-1291$ & Arghun \\
$1291-1295$ & Geikhatu \\
1295 & Baidu \\
$1295-1304$ & Mahmud Ghazan \\
$1304-1316$ & Muhammad Kharbandah Oljeitu \\
$1316-1335$ & Abu Said Bahadur
\end{tabular}

\section{Rulers of the Kingdom of Cilician Armenia}

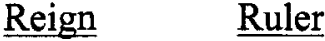

1226-1270 Hetum I

1270-1289 Lewon II

1289-1293 Hetum II

1293-1298 Toros III

1295-1296 Hetum II, co-ruler with Toros III

1296-1298 Sempad, usurper

1298-1299 Constantine I

1299-1303 Hetum II, reclaimed the throne, abdicated and regent for Lewon III

1303-1307 Lewon III, under regency of Hetum II

1307-1320 Oshin

1320-1341 Lewon IV

1342-1344 Constantine II

1344-1362 Constantine III

1362-1373 Constantine IV

1374-1375 Lewon V 
Sultans of the Mamluk Kingdom of Egypt

Reign $\quad$ Ruler

1250-1257 Al-Muizz Aybeg al-Turkmani

1257-1259 Al-Mansur Ali b. Aybeg

$1259 \quad$ Al-Muzaffar Qutuz

1260-1277 Al-Zathir Baybars al-Bunduqdari

1277-1279 Al-Said Berke Khan b. Baybars

1279 Al-Adil Sulamish b. Baybars

1279-1290 Al-Mansur Qalawun b. Alfi

1290-1293 Al-Ashraf Khalil b. Qalawun

1293-1294 Al-Nasir Muhammad b. Qalawun (first reign)

1294-1296 Al-Adil Ketbugha

1296-1299 Al-Mansur Lachin

1299-1309 Al-Nasir Muhammad b. Qalawun (second reign)

1309-1310 Al-Muzaffar Baybars al-Jashnakir

1310-1340 Al-Nasir Muhammad b. Qalawun (third reign)

1340-1382 Various descendants of al-Nasir Muhammad until 1382 


\section{MAPS}

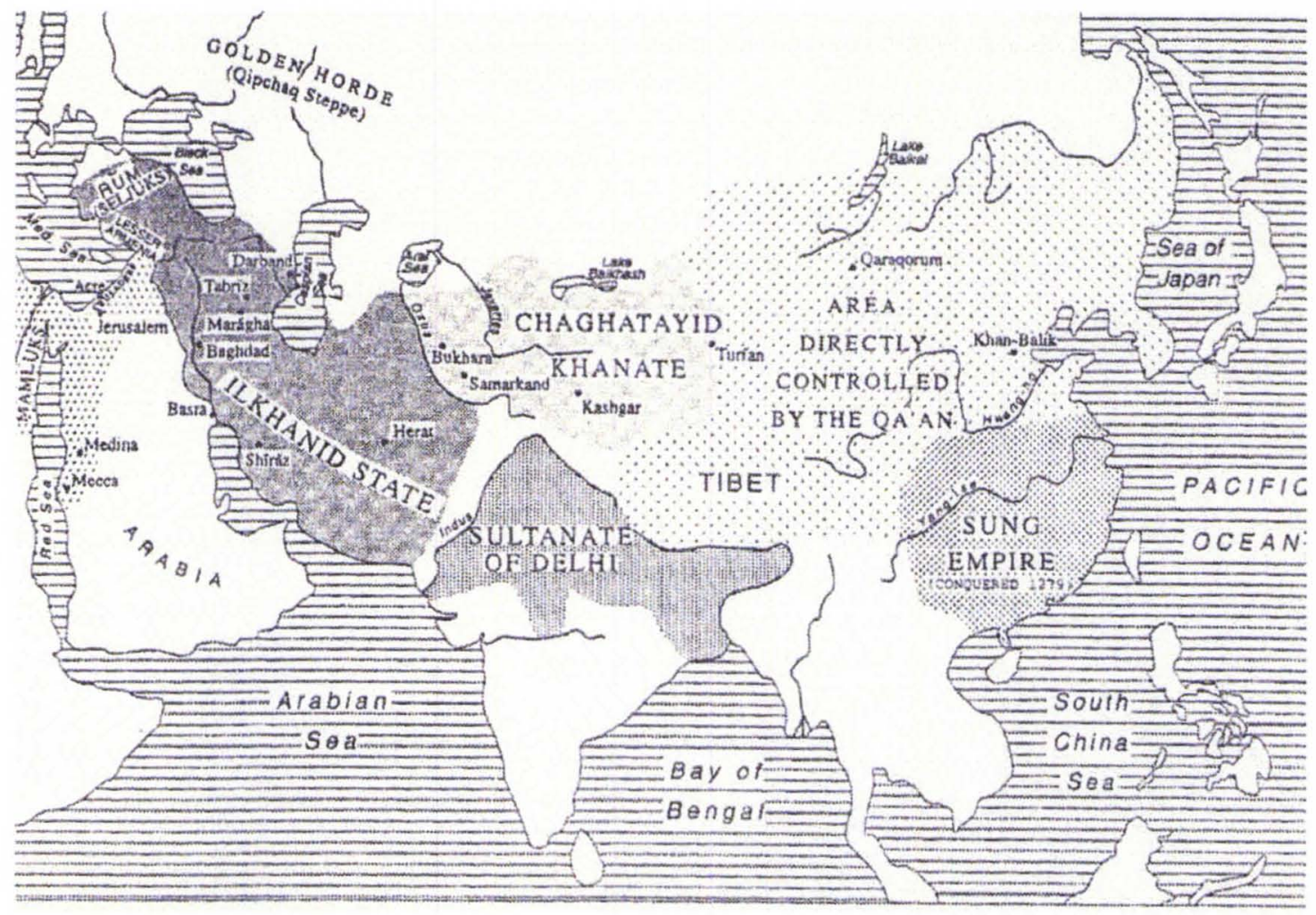

Map 1. Asia after $1260 \mathrm{CE}$, showing territory under Mongol control and the Mongol Khanates. ${ }^{271}$

${ }^{271}$ Amitai Preiss, The Mamluk-Ilkhanid War, 236. 


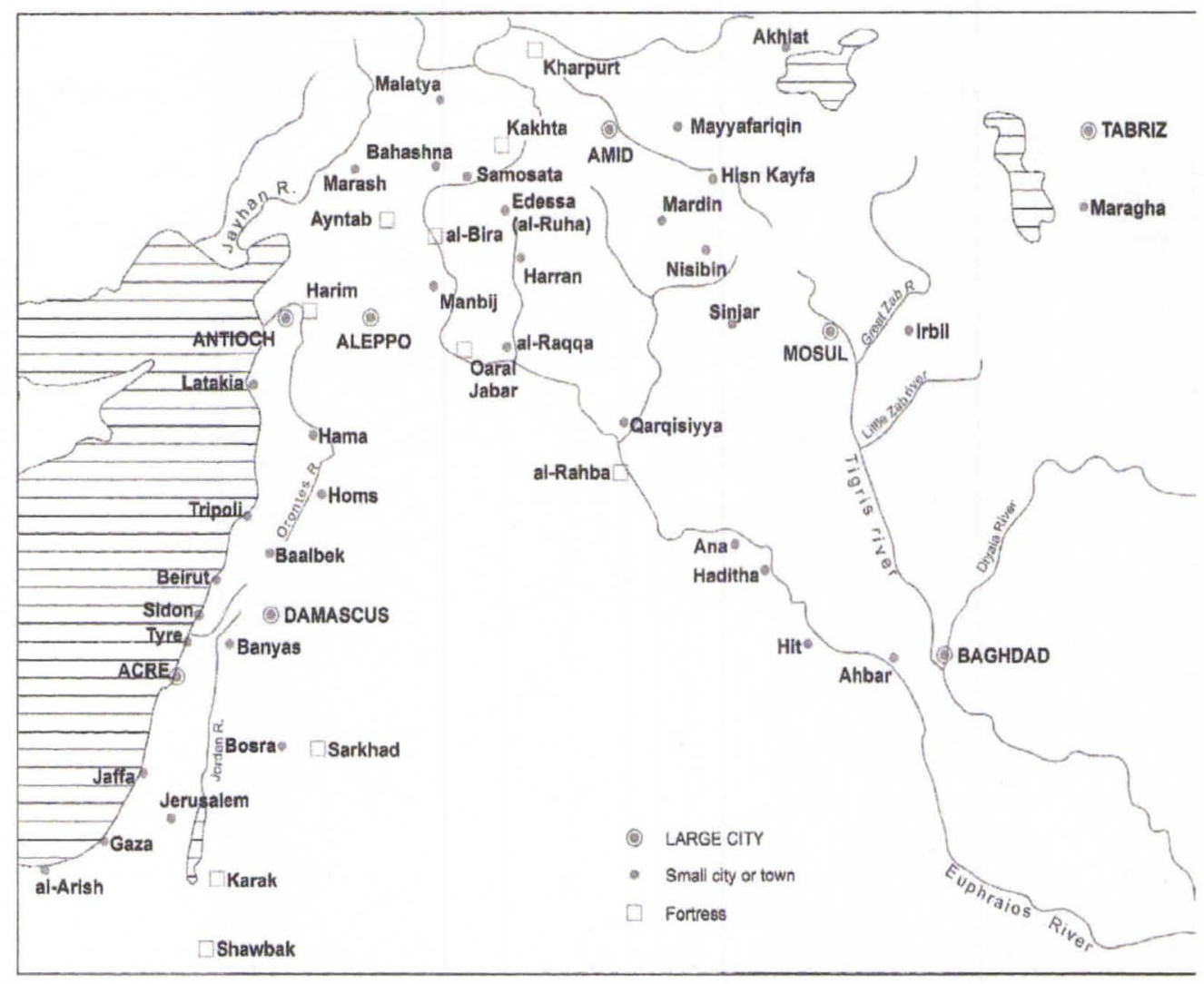

Map 2. The Mongols in the Middle East. ${ }^{272}$

${ }^{272}$ Dashdondog, The Mongols and Armenians, xviii. 


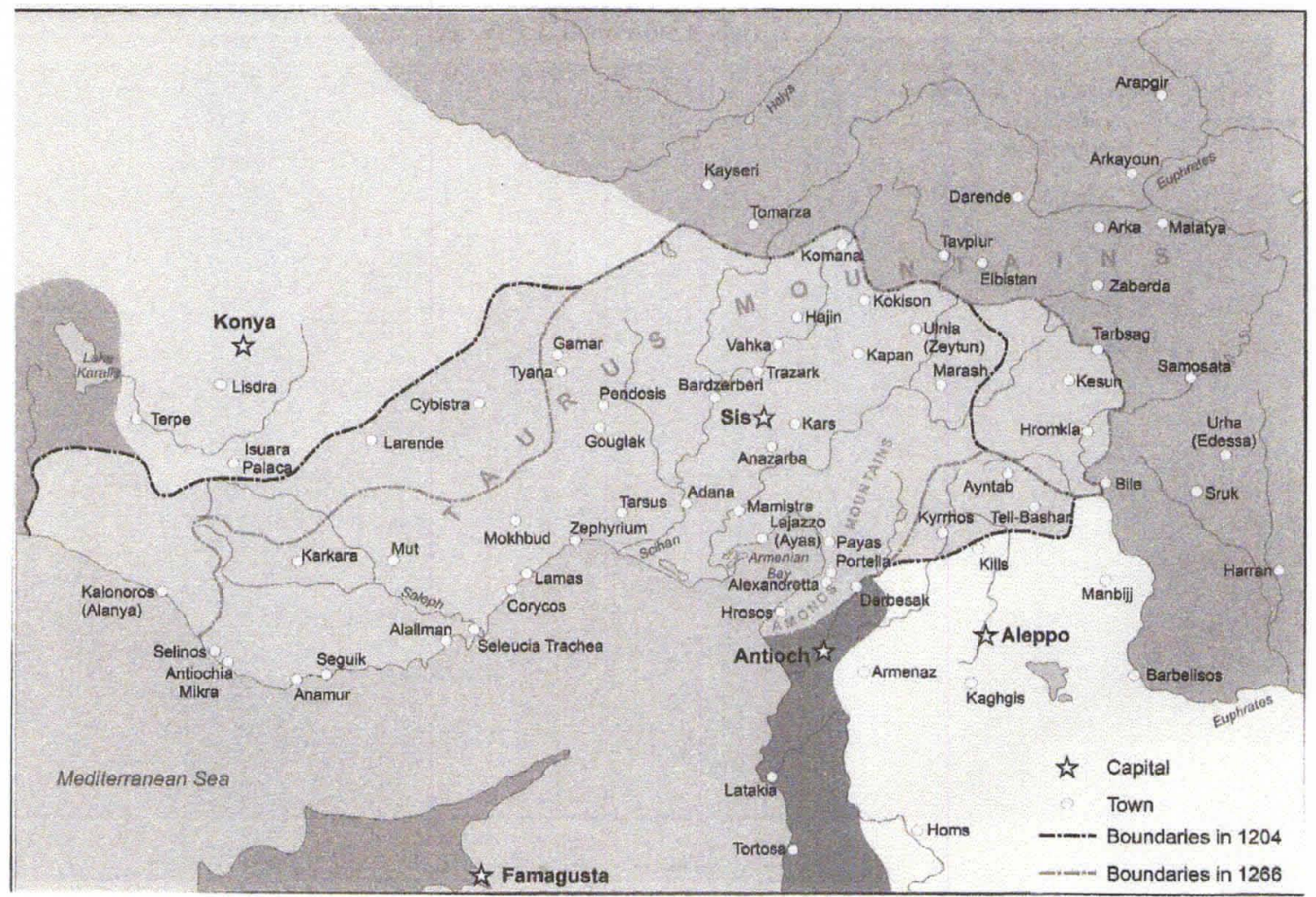

Map 3. The Kingdom of Cilician Armenia (1199-1375). ${ }^{273}$

${ }^{273}$ Dashdondog, The Mongols and Armenians, $\mathrm{xv}$. 


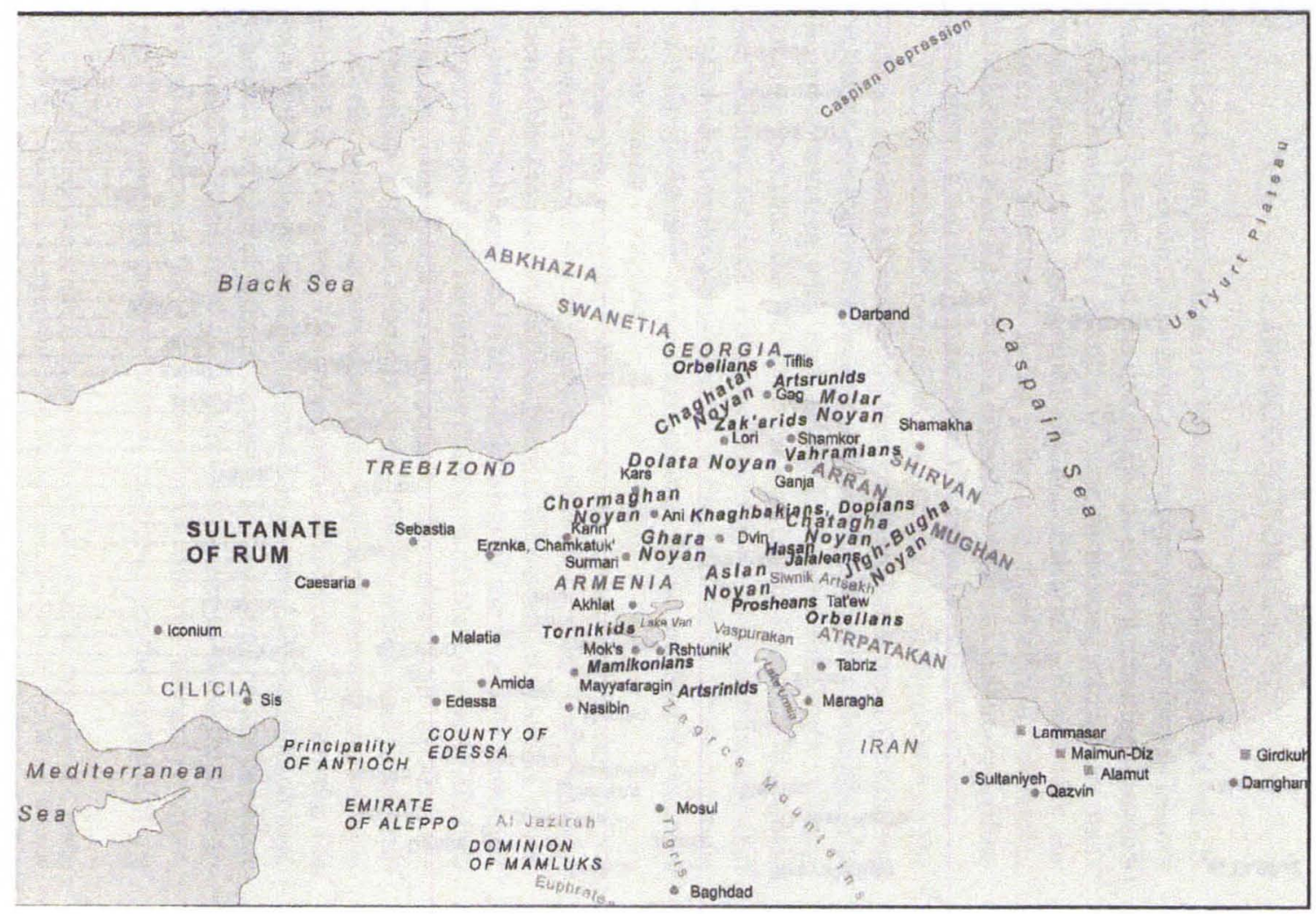

Map 4. The Mongol commanders (noyans) and the Greater Armenian houses. ${ }^{274}$

${ }^{274}$ Dashdondog, The Mongols and Armenians, xvii. 


\title{
CURRICULUM VITAE
}

\author{
Lauren M. Prezbindowski \\ 428 West Ormsby Ave. Louisville, KY 40203 \\ Phone: $260-438-0208$ \\ lprezbindowski@gmail.com
}

\section{Education:}

Masters of Arts, University of Louisville, December 2012.

Major: History. Concentrations: Comparative World, Public History.

Cumulative Grade Point Average: 3.96/4.0.

Thesis: The Ilkhanid Mongols, the Christian Armenians, and the Islamic Mamluks:

A Study of Their Relations, 1220-1335.

Bachelor of Arts, Hanover College, May 2008.

Major: History. Minor: Classical Studies.

Thesis: The Hellenistic Period in the Ancient Mediterranean: A Two Fold Distinction between the Immediate Successors of Alexander the Great and the Later Hellenistic Kings.

\section{Occupational Experience:}

Exhibition Project Manager, "Spirits of the Passage: the Story of the Transatlantic Slave Trade," Frazier History Museum, Louisville, KY, September 2011 to present.

- Acted as overall coordinator for the project.

- Researched all visual content for the exhibit.

- Wrote and edited all text content, including text panels, case and artifact labels.

- Coordinated all communications and travel arrangements for scholars, community advisors and staff.

- Set and managed exhibition schedule.

Advancement Associate, Frazier History Museum, May 2011 to present.

- Head of the Museum's application and process through the American Association of Museums' Museum Assessment Program for Community Engagement.

- Wrote grant narratives and budgets for corporate and foundation applications. 
- Acted as primary data entry associate in Raisers Edge.

- Conducted foundation and corporate prospecting.

- Wrote appeal, receipt/thank you letters.

Independent Exhibition Curator, Crane House the Asia Institute, January 2011 to August 2011.

- Researched all scholarly content for the exhibit.

- Wrote all exhibit text, including text panels and artifact labels.

- Coordinated exhibition style and installation.

- Presented a public scholarly lecture on a topic relating to the exhibit.

Development \& Marketing Associate, Frazier History Museum, June 2010- May 2011.

- Created and led summer volunteer program.

- Researched and wrote museum volunteer training manuals.

- Led volunteer in-service training and exhibition training.

- Wrote job descriptions and conducted interviews for interns and volunteers.

- Continued as lead facilitator for the museum's AAM Institutional Assessment.

Development Intern, Frazier History Museum, July 2009- June 2010.

- Researched scholarly material and acquisitions for temporary in-house fabricated exhibitions.

- Aided in the fabrication and installation of temporary exhibitions.

- Project managed the museum's Institutional Assessment of the American Association of Museums.

- Wrote grant applications, researched prospective foundations and created a foundation master list.

Collections Research Intern, Conner Prairie Museum, Summer 2007.

- Researched historical material and wrote a research article, entitled "White Settler and Lenape Relations on the White River, 1801-1806," to provide information for the education of the public at the Conner Prairie facility.

- Worked with staff in discussing the research needs of Conner Prairie and the best methods for educating the public.

- Delivered a research presentation to the public and academic community.

Competencies \& Training:

- Indiana African American Heritage Trail, Progressive Journey Conference, "Indiana's Legacy of Slavery, Indentured Servitude, and Pioneer Justice," October 2012.

- Presenter, Ohio Valley History Conference, Murray State University, October 2011. 
- American Association of Museums Professional Development series.

- Study Abroad experience: Athens, Olympia, Delphi, Greece, April-May 2008.

- Foreign language competency: Latin, ancient Greek.

- Black belt, Tae Kwon Do, January 2007 to present.

\section{Computer Skills:}

- Microsoft Word, Excel, Powerpoint, Outlook, Publisher.

- The Raiser's Edge.

- Foundation Database.

- Teambox and DropBox

- Basecamp

Professional Memberships:

- American Association of Museums (AAM).

- Association of Fundraising Professionals (AFP).

- Kentucky Association of Volunteer Administration (KAVA).

- Lilly Scholars Alumni.

Academic Honors and Scholarships:

- Thomas Hamilton Graduate Scholarship, University of Louisville, August 2010.

- Phi Alpha Theta, History Honors Society.

- Phi Sigma Iota Classics and Foreign Language Honor Society.

- Departmental Honors, History Department, Hanover College, May 2008.

- Cum Laude graduate, Hanover College, May 2008.

- Dean's List, Hanover College, Fall 2006- Spring 2008.

- Lilly Endowment Scholar, Class of 2004, 2004-2008.

- Hanover Academic Scholarship, 2004-2008.

- Hanover Music Scholarship, 2004-2005.

- Academic Honors Higher Education Award, State of Indiana; Academic Freedom of Choice Grant, State of Indiana; Federal Pell Grant, 2004-2008; Salutatorian, Wayne High School, May 2004. 